Universidade de Brasília

Faculdade de Ciências de Saúde

Departamento de Enfermagem

Programa de Pós-Graduação em Enfermagem

DANIELLA MELO ARNAUD SAMPAIO PEDROSA

ANÁLISE ESPACIAL DOS CASOS NOVOS DE TUBERCULOSE POR REGIONAL

DE SAÚDE DO DISTRITO FEDERAL, 2003 A 2012.

BRASÍLIA

2016 


\author{
UNIVERSIDADE DE BRASÍLIA \\ FACULDADE DE CIÊNCIAS DE SAÚDE \\ DEPARTAMENTO DE ENFERMAGEM \\ PROGRAMA DE PÓS-GRADUAÇÃO EM ENFERMAGEM
}

DANIELLA MELO ARNAUD SAMPAIO PEDROSA

\title{
ANÁLISE ESPACIAL DOS CASOS NOVOS DE TUBERCULOSE POR REGIONAL \\ DE SAÚDE DO DISTRITO FEDERAL, 2003 A 2012.
}

Dissertação apresentada como requisito parcial para a obtenção parcial do Título de Mestre em Enfermagem pelo Programa de Pós-Graduação em Enfermagem da Universidade de Brasília. Área de Concentração: Cuidado, Gestão e Tecnologia em Saúde e Enfermagem.

Linha de Pesquisa: Gestão de Sistemas e de Serviços em Saúde e Enfermagem

Orientador: Maria do Socorro Nantua Evangelista

BRASÍLIA 
Ficha catalográfica elaborada automaticamente, com os dados fornecidos pelo(a) autor(a)

Melo Arnaud Sampaio Pedrosa, Danielia

ANÁLISE ESPACTAL DOS CASOS NOVOS DE TUBERCULOSE ROR REGIONAL DE SAÚdE DO DISTRITO FEDERAL, $2003 \mathrm{~A}$ 2012 / Danielia Melo Arnaud Sampaio Pedrosas orientador Maria do Socorro Nantua Evangelista. -Brasilia, 2016.

$99 \mathrm{p}$.

Dissertaço (Mestrado - Mestrado em Enfernagem) Universidade de Brasilia, 2016.

1. Tuberculose. 2. Sistemas de Informaçlo Geogratica. 3. Vulnerabilidade Social. I. Nantua Evangelista, Maria do Socorro, orient. II. Titulo. 
DANIELLA MELO ARNAUD SAMPAIO PEDROSA

\section{ANÁLISE ESPACIAL DOS CASOS NOVOS DE TUBERCULOSE POR REGIONAL DE SAÚDE DO DISTRITO FEDERAL, 2003 A 2012.}

Dissertação apresentada como requisito parcial para a obtenção parcial do Título de Mestre em Enfermagem pelo Programa de Pós-Graduação em Enfermagem da Universidade de Brasília. Área de Concentração: Cuidado, Gestão e Tecnologia em Saúde e Enfermagem.

Linha de Pesquisa: Gestão de Sistemas e de Serviços em Saúde e Enfermagem

Aprovado em 05 de setembro de 2016

BANCA EXAMINADORA

Professora Doutora Maria do Socorro Nantua Evangelista - Presidente da Banca

Universidade de Brasília

Professor Doutor Rômulo José da Costa Ribeiro - Membro Efetivo, Externo ao Programa Universidade de Brasília

Professora Doutora Dirce Bellezi Guilhen - Membro Efetivo

Universidade de Brasília

Professora Doutora Maria Cristina Soares Rodrigues - Membro Suplente Universidade de Brasília 
Dedico este trabalho à minha mãe Fátima, pelo seu amor e apoio que me inspiraram a prosseguir nesta jornada. Ao meu marido Jorge pela ajuda e incentivo. Aos meus avós Alcione e Kelita (in memória), que me ensinaram com seus exemplos a lutar e persistir para alcançar os meus objetivos. 


\section{AGRADECIMENTOS}

Agradeço a Deus, razão do meu viver, porque sem ele nada seria possível.

Agradeço às pessoas que contribuíram para a realização desta conquista.

Agradecimento especial à minha orientadora, Professora Dr. ${ }^{a}$ Maria do Socorro Nantua Evangelista, que dedicou seu tempo e atenção para a realização deste trabalho.

Ao meu coorientador, Professor Dr. Rômulo José da Costa Ribeiro, pela sua dedicação, paciência e por ter me ensinado a fazer as análises espaciais para este estudo.

À professora Dr. ${ }^{a}$ Dirce Bellezi Guilhen, que me recebeu com muito zelo e atenção no programa de Pós-Graduação e por ter feito as orientações iniciais para a realização do trabalho.

À Professora e Coordenadora do Programa de Pós-Graduação em Enfermagem da UnB, Dr. ${ }^{a}$ Maria Cristina Soares Rodrigues, pelo apoio, incentivo e ensinamentos dados a mim durante a jornada do mestrado.

À minha família, que me apoiou nos momentos mais difíceis, especialmente o meu marido que compartilhou seu carinho e atenção para tornar este trabalho possível. Aos meus pais, todo meu amor e respeito e pelo apoio e incentivo parar tornar os meus sonhos possíveis. À minha irmã Rebeca, que me estimulou a prosseguir e não desistir.

Aos profissionais da Diretoria de Vigilância Epidemiológica (DIVEP) e da Companhia de Planejamento do Distrito Federal (CODEPLAN), que contribuíram com os dados para a realização da pesquisa. À equipe do laboratório de Geoprocessamento da UCB, que me auxiliou na elaborarão das cartografias.

Aos meus colegas de trabalho da Universidade Católica de Brasília, pelo apoio, encorajamento e carinho, pois sem eles o presente estudo não seria possível.

Aos meus alunos, que me apoiaram e me ensinam tanto a cada dia, em especial a minha exaluna Thaís, pelo incentivo e por ter dedicado seu tempo me auxiliando no uso dos recursos tecnológicos. 
"Que os vossos esforços desafiem as impossibilidades, lembrai-vos de que as grandes coisas do homem foram conquistadas do que parecia impossivel". 


\section{RESUMO}

PEDROSA, Daniella Melo Arnaud Sampaio. Análise espacial dos casos novos de tuberculose por regional de saúde do Distrito Federal, 2003 a 2012. 2016. 99 p. Dissertação (Mestrado)

- Departamento de Enfermagem, Faculdade de Ciências da Saúde, Universidade de Brasília, Brasília, 2016.

INTRODUÇÃO: A compreensão da distribuição da carga da tuberculose (TB) no Distrito Federal (DF) é importante para orientar as ações de controle da enfermidade, particularmente, em área de baixa incidência de TB. OBJETIVO: analisar espacialmente os casos novos de tuberculose por regional de saúde do Distrito Federal, no período de 2003 a 2012. MATERIAIS E MÉTODOS: Trata-se de um estudo transversal, realizado com 3.282 casos novos de TB do Programa de Tuberculose do DF, entre 2003 a 2012. Os dados foram obtidos do Instituto Brasileiro de Geografia e Estatística, Companhia de Planejamento do Distrito Federal e do Sistema Nacional de Agravos de Notificação. As análises consideraram as seguintes variáveis indepedentes: escolaridade, fecundidade, renda, envelhecimento, ocupação do lar, violência e mortalidade. Para a análise espacial, os dados foram georreferenciados no Google Earth Pro, processados no Sistema de Informação Geográfica (SIG) ArcGIS 10.3, pelo método Inverso da Distância Ponderada (IDW), por regional de saúde. Para o cálculo da tendência da série histórica do coeficiente de incidência (CI) da TB (2003 a 2012), utilizou-se a técnica de regressão linear simples para avaliação da variação temporal. Para analisar a associação de variáveis sociais e o CI de TB, aplicou-se o coeficiente de correlação de Spearman, com nível de significância de $5 \%$ e o software utilizado foi o SPSS, versão 18.0. O estudo foi aprovado pelo Comitê de Ética em Pesquisa da Secretaria de Estado de Saúde do DF, Parecer $n^{\circ}$ 1.037.141. RESULTADOS: Nos 10 anos do estudo, constatou-se que houve redução do CI de TB em 2,2\% no DF, com maior CI em homens. O risco de adoecimento foi maior em idosos (60 anos ou mais) nos oito primeiros anos (2003 a 2010), passando a ser maior em adultos jovens (25 a 59 anos) a partir de 2011. A TB migrou das regionais de Santa Maria e Núcleo Bandeirante para dois novos núcleos, o Paranoá e São Sebastião, com maior proximidade entre os casos associada a observação de elevada migração em ambas áreas e vulnerabilidade social. CONCLUSÃO: Os determinates como fecundidade, ocupação do lar, violência, mortalidade e a proporção de analfabetos aumentaram a incidência de TB, com significado estatístico, porém, o aumento do envelhecimento e da renda diminuiram o CI de TB. A cura, de forma geral, não se associou à incidência de TB e aos indicadores sociais analisados. Novos estudos devem identificar em que medida as vulnerabilidades, os incentivos sociais governamentais e o monitoramento permanente dos casos de TB devido ao processo migratório contribuem para minimizar o risco de adoecimento nas áreas de maior carga da doença no DF.

Palavras-Chaves: Tuberculose; Sistemas de Informação Geográfica; Vulnerabilidade Social. 


\begin{abstract}
PEDROSA, Daniella Melo Arnaud Sampaio. Spatial analysis of new cases of tuberculosis by Health Service Regions of the Federal District, from 2003 to 2012. 2016. 99 p. Dissertation (Mastership) - Department of Nursing, Faculty of Health Sciences, University of Brasília, Brasília, 2016.
\end{abstract}

INTRODUCTION: Understanding the distribution of tuberculosis burden (TB) in the Federal District (DF) of Brazil is important to guide the disease control actions, particularly in low TB incidence area. OBJECTIVE: spatially analyze the new cases of TB by Health Service Regions in DF, from 2003 to 2012. MATERIALS AND METHODS: It is a cross-sectional study with 3,282 new cases of TB of the Federal District Tuberculosis Program, between 2003 and 2012. Data were provided by the Brazilian Institute of Geography and Statistics (IBGE), Federal District Planning Company (CODEPLAN) and the National Notifiable Diseases System. The analyses considered independent variables: education, fertility, income, age, home occupation, violence and death. For spatial analysis, data were georeferenced in Google Earth Pro, processed in Geographic Information System (GIS) ArcGIS 10.3, the Inverse Distance Weighting (IDW), by Health Service Regions. To calculate the trend of the series in the TB incidence rate (2003-2012), simple linear regression was used to evaluate the temporal variation. To analyze the relationship between social variables and TB incidence rate, Spearman correlation coefficient was applied, with a significance level of 5\% and software used was SPSS, version 18.0. The study was approved by the Research Ethics Committee of the Federal District Department of Health, through Opinion No. 1,037,141. RESULTS: Over the 10 years of the study it was found that there was a reduction of TB incidence rate $2.2 \%$ in the Federal District, with higher incidence rate among men. The risk of illness was higher in the elderly (60 or older) in the first eight years (2003-2010), becoming higher in young adults (25 and 59 years) from 2011. TB migrated from Health Service Regions of Santa Maria and Nucleo Bandeirante to two new regions, Paranoá and São Sebastião, with greater proximity between the cases associated with high migration in both areas and social vulnerability. CONCLUSION: The determinats such as fecundity, home occupation, violence, mortality and the proportion of illiterates increased the incidence of $\mathrm{TB}$, with statistical significance and, but the increase of aging and income, decreased the TB incidence rate. The cure was, in general, not associated with the incidence of TB and social indicators analyzed. Further studies should identify to what extent the vulnerabilities, government social incentives and the permanent monitoring of TB cases due to the migration process contribute to minimize the risk of disease in areas of higher disease burden in DF.

Keywords: Tuberculosis; Geographic Information Systems; Social vulnerability. 


\section{RESUMEN}

PEDROSA, Daniella Melo Arnaud Sampaio. Análisis espacial de los nuevos casos de tuberculosis por regional de servicio de salud del Distrito Federal, 2003 hasta 2012. 2016. 99 p. Tesis (Maestría) - Departamento de Enfermería de la Facultad de Ciencias de la Salud, Universidad de Brasília, Brasília, 2016.

INTRODUCCIÓN: La comprensión de la distribución de la carga de tuberculosis (TB) en el Distrito Federal (DF) es importante para guiar las acciones de control de la enfermedad, sobre todo en las áreas de baja incidencia de TB. OBJETIVO: analizar espacialmente los nuevos casos de tuberculosis por regional de servicio de salud del Distrito Federal, de 2003 hasta 2012. MATERIALES Y MÉTODOS: Se trata de un estudio transversal con 3.282 nuevos casos de TB registrados en el Programa de la tuberculosis del DF, entre 2003 y 2012. Los datos se obtuvieron del Instituto Brasileño de Geografía y Estadística (IBGE), la Empresa de Planificación del Distrito Federal (CODEPLAN) y del Sistema Nacional de Enfermedades de Declaración Obligatoria. El análisis tuvo en cuenta las siguientes variables independientes: educación, fertilidad, ingresos, edad, ocupación, violencia y muerte. Para el análisis espacial, los datos fueron georreferenciados en Google Earth Pro, procesados en el Sistema de Información Geográfica (SIG) ArcGIS 10.3, con base en el método del inverso de la distancia ponderada (IDW), por regional de servicio de salud. Para calcular la tendencia de la serie histórica del coeficiente de incidencia (CI) de la TB (2003-2012), se utilizó la regresión linear simples para evaluar la variación temporal. Para analizar la relación entre las variables sociales y el CI de la TB, se aplicó el coeficiente de correlación de Spearman, con un nivel de significación del 5\% y el software utilizado fue el SPSS, versión 18.0. El estudio fue aprobado por el Comité de Ética de la Secretaría de Estado de Salud del Distrito Federal, Opinión No. 1.037.141. RESULTADOS: En los 10 años del estudio, se encontró una reducción del CI de la tuberculosis de 2,2\% en el Distrito Federal, con valores más altos de CI en los hombres. El riesgo de la enfermedad ha sido mayor en los ancianos (60 años o más) en los primeros ocho años (2003-2010), cambiando para los adultos jóvenes (25-59 años) a partir del 2011. La TB migró de las regionales de salud de Santa María y Núcleo Bandeirantes para las regionales del Paranoá y San Sebastián, con una mayor proximidad entre los casos relacionados con la observación de alta migración en ambas áreas y la vulnerabilidad social. CONCLUSIÓN: Los determinantes como la fecundidad, ocupación, violencia, mortalidad y la proporción de analfabetos fueran responsables por el aumentó en la incidencia de la tuberculosis, con significación estadística, sin embargo, el aumento del envejecimiento y renta causó reducción del CI de la TB. La curación, en general, no se asoció con la incidencia de la tuberculosis y los indicadores sociales analizados. Nuevos estudios deberán identificar en qué medida las vulnerabilidades, los incentivos sociales del gobierno y el monitoreo permanente de los casos de tuberculosis debido al proceso de migración contribuyen para minimizar el riesgo de enfermedad en las zonas de alta carga de morbilidad en el Distrito Federal.

Palabras clave: Tuberculosis; Sistemas de Información Geográfica; La vulnerabilidad social. 


\section{LISTA DE FIGURAS}

Figura 1. Coeficiente de incidência por 100.000 habitantes da tuberculose no Distrito Federal, período de 2003 a 2012.

Figura 2. Coeficiente de incidência e linha de tendência da tuberculose segundo faixa etária no Distrito Federal, período de 2003 a 2012.

Figura 3. Mapa do IDW dos casos de tuberculose por Regional de Saúde do

Distrito Federal - 2003.

Figura 4. Mapa do IDW dos casos de tuberculose por regional de saúde do DF 69 2012 .

\section{LISTA DE QUADROS}

Quadro 1. Regionais de Saúde e suas respectivas Regiões Administrativas do Distrito Federal.....

\section{LISTA DE TABELAS}

Tabela 1. Coeficiente de incidência da tuberculose por regional e ano de diagnóstico no Distrito Federal, período de 2003 a 2012

Tabela 2. Coeficiente de incidência dos casos novos de tuberculose, segundo sexo, por regional de saúde do Distrito Federal, período de 2003 a 2012.

Tabela 3. Coeficiente de incidência de tuberculose segundo faixa etária por regionais de saúde. Distrito Federal, 2003 a 2012.

Tabela 4. Taxa de cura de tuberculose segundo regional e ano de diagnóstico. Distrito Federal, 2003 a 2012.

Tabela 5. Correlação entre o coeficiente de incidência, taxa de cura e indicadores de determinantes sociais. Distrito Federal, 2003 a 2012.

Tabela 6. Correlação entre o coeficiente de incidência com a cura e com indicadores de determinantes sociais por regional de saúde. Distrito Federal, 2003 
Tabela 7. Correlação entre a distância média percorrida pelo paciente até e a unidade de tratamento da tuberculose, e o percentual de cura. Distrito Federal, 2003 a 2012.

Tabela 8. Distância mínima e máxima percorrida pelo paciente até e a unidade de tratamento da tuberculose, por regional de saúde do Distrito Federal, período de 2003 a 2012. 


\section{LISTA DE SIGLAS}

$\begin{array}{ll}\text { BAAR } & \text { Bacilo álcool-ácido resistente } \\ \text { BCG } & \text { Bacilo de Calmette-Guérin } \\ \text { CI } & \text { Coeficiente de incidência } \\ \text { CMI } & \text { Coeficiente médio de incidência } \\ \text { DDS } & \text { Determinantes Sociais } \\ \text { DF } & \text { Distrito Federal } \\ \text { E } & \text { Etambutol } \\ \text { ESF } & \text { Estratégia Saúde da Família } \\ \text { Et } & \text { Etionamida - Et } \\ \text { H } & \text { Isoniazida } \\ \text { HIV } & \text { Vírus da imunodeficiência humana } \\ \text { IBGE } & \text { Instituto Brasileiro de Geografia e Estatística } \\ \text { IDW } & \text { Inverso da Distância Ponderada } \\ \text { IGRA } & \text { Interferon Gamma Release Assay } \\ \text { ILTB } & \text { Infecção latente da TB } \\ \text { INF-y } & \text { Interferão gama } \\ \text { MTB } & \text { Mycobacterium tuberculosis } \\ \text { OMS } & \text { Organização Mundial de Saúde } \\ \text { PACS } & \text { Programa de Agente Comunitário de Saúde } \\ \text { PCR } & \text { Reação em cadeia da polimerase } \\ \text { PDAD } & \text { Pesquisa Distrital por Amostra de Domicílios } \\ \text { PET } & \text { Tomografia com Emissão de Pósitrons } \\ \text { PNCT } & \text { Programa Nacional de Controle da Tuberculose } \\ \text { PT } & \text { Prova tuberculínica } \\ \text { R } & \text { Rifampicina } \\ \text { RAs } & \text { Regiões Administrativas } \\ \text { RHZ } & \text { Esquema de tratamento padrão } \\ \text { RM } & \text { Ressonância Magnética } \\ \text { S } & \text { Estreptomicina } \\ \text { S. I. A } & \text { Setor de Indústria e Abastecimento } \\ \text { SCIA } & \text { Setor Complementar de Indústria e Abastecimento } \\ \text { SIA } & \text { Setor de Indústria e Abastecimento } \\ \text { SIG } & \text { Sistema de Informação Geográfica } \\ \text { SINAN } & \text { Sistema de Informação de Agravos de Notificação } \\ \text { SN } & \text { Salários mínimos } \\ \text { SR } & \text { Sintomáticos respiratórios } \\ \text { SUS } & \text { Sistema Único de Saúde } \\ \text { TB } & \text { Tuberculose } \\ \text { TBMR } & \text { Tuberculose resistente à Rifampicina adquirida } \\ \text { TCAR } & \text { Tomografia computadorizada de alta resolução } \\ \text { TDO } & \text { Tratamento Diretamente Observado } \\ \text { Z } & \text { Pirazinamida } \\ & \end{array}$




\section{SUMÁRIO}

APRESENTAÇÃ

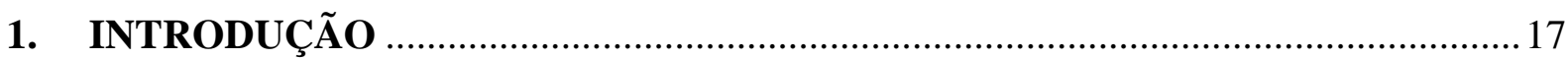

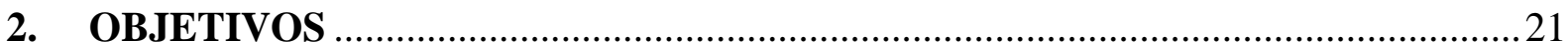

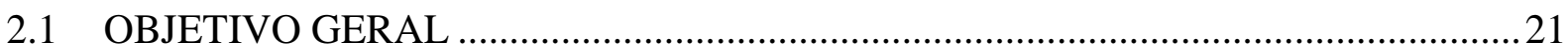

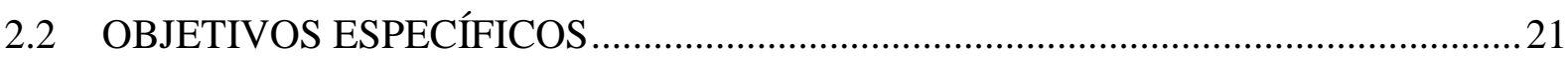

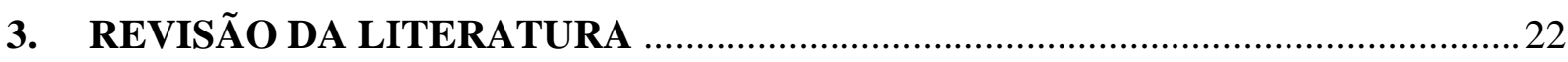

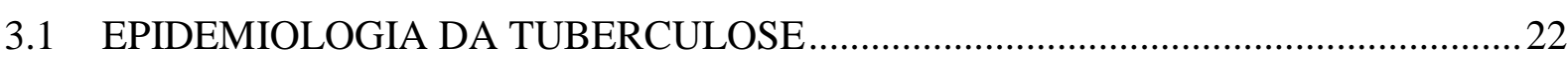

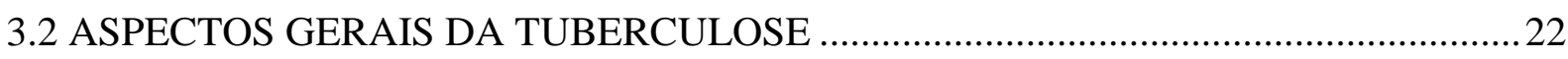

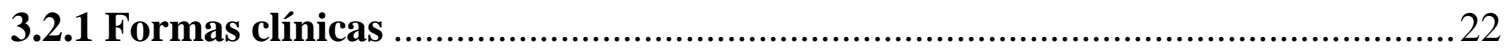

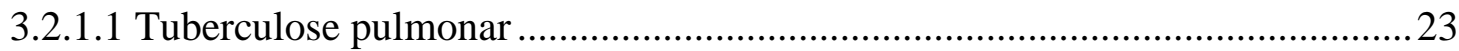

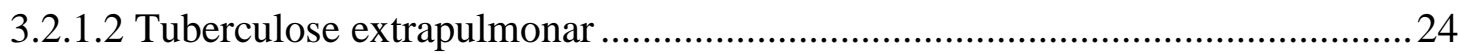

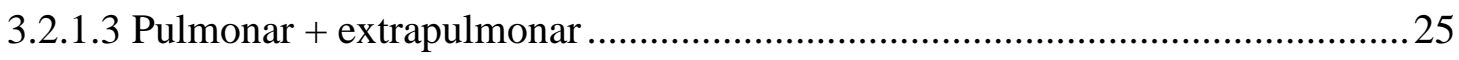

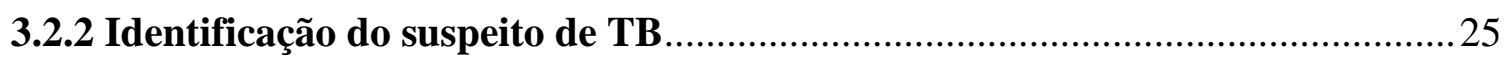

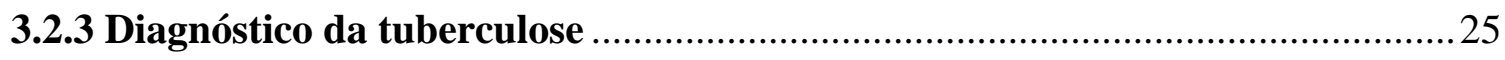

3.2.3.1 Bacteriológica ....................................................................................... 25

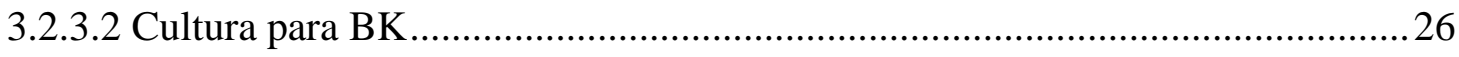

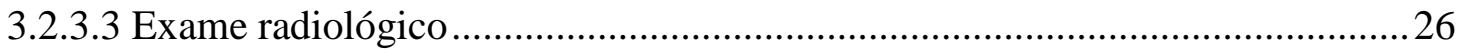

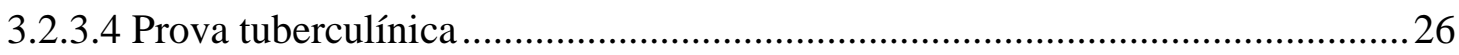

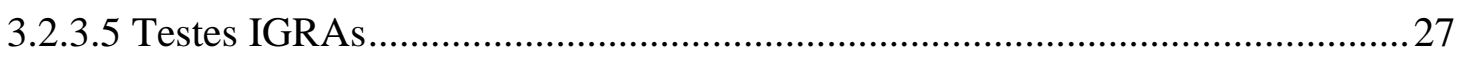

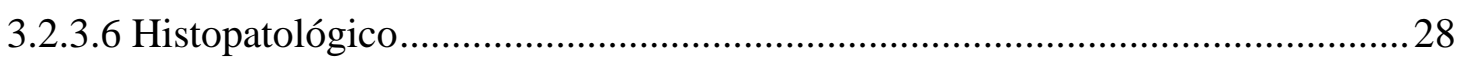

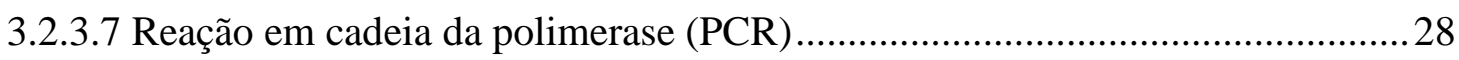

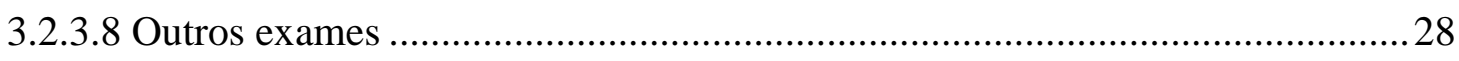

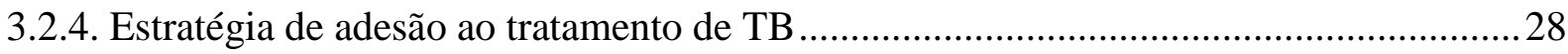

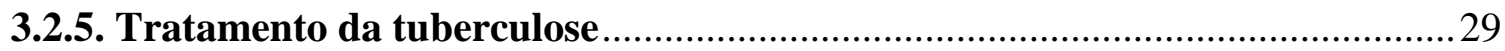

3.2.6. A imunologia na tuberculose ......................................................................... 30

3.3 DETERMINANTES SOCIAIS E A TUBERCULOSE …………………………............

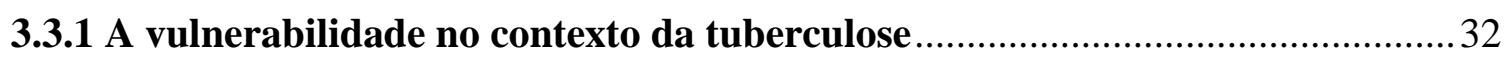

3.3.2 Tuberculose, acessibilidade e acolhimento …………………………………......... 38

3.4 PROGRAMA NACIONAL DE CONTROLE DA TUBERCULOSE (PNCT) ...................39

3.5 USO DO GEOPROCESSAMENTO PELO SETOR SAÚDE...........................................42

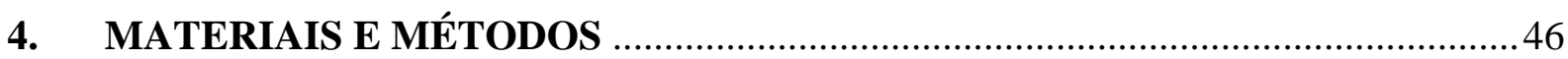




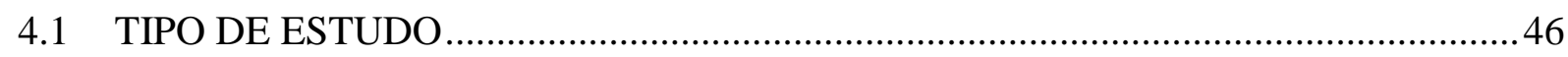

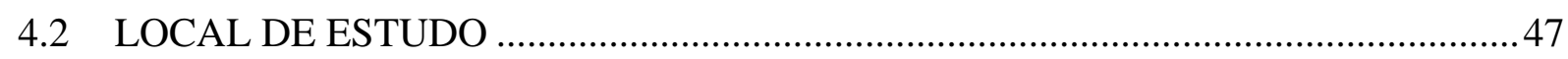

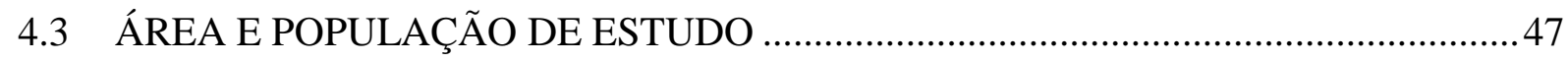

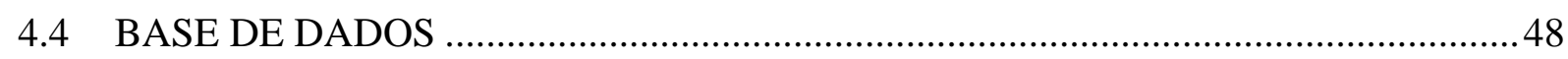

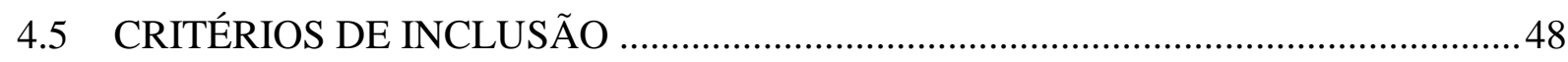

4.6. CLASSIFICAÇÃO DE "CASO", "CURA" "FORMA PULMONAR", "EXTRAPULMONAR", "PULMONAR + EXTRAPULMONAR” DA TUBERCULOSE E

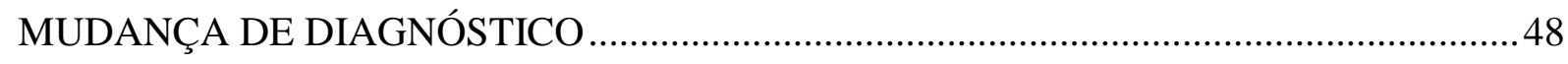

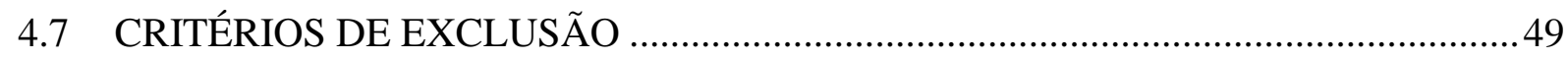

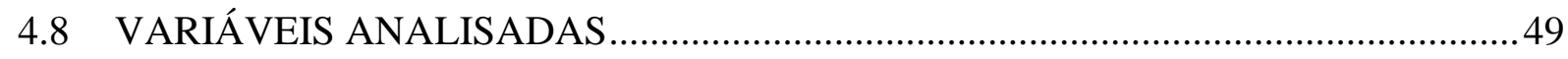

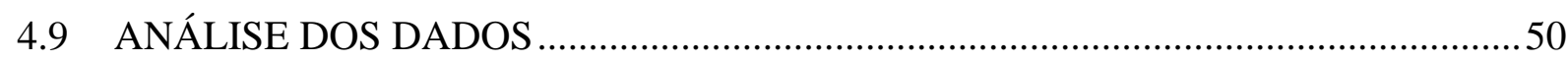

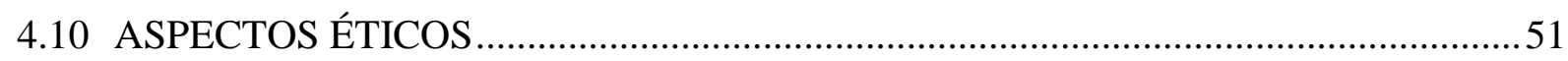

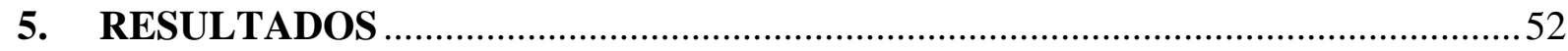

6. DISCUSS ÃO

7. CONCLUSÃO

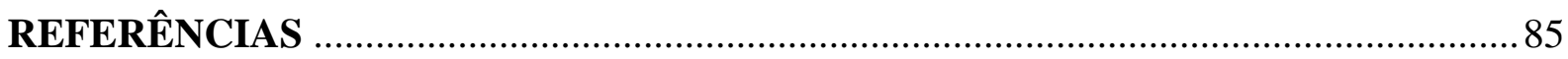

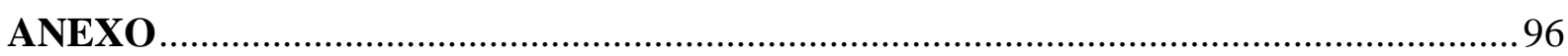




\section{APRESENTAÇÃO}

O tema análise espacial dos casos novos de tuberculose surgiu a partir de discussões com a professora Maria do Socorro Nantua Evangelista sobre a magnitude e a importância de se estudar a doença tuberculosa no Distrito Federal. A partir daí, foram realizadas pesquisas na literatura para compreender melhor a doença e, durante essas leituras, observou-se que que países com o Iran, Argentina e Espanha estavam utilizando a ferramenta geoprocessamento para compreender como o agravo se comportava na população.

Tal fato despertou o desejo de aplicar o geoprocessamento (análise espacial) na área da saúde a fim de observar os resultados que esta ferramenta poderia apresentar no panorama da tuberculose no Distrito Federal. Para isso cursei a disciplina Geoprocessamento do Programa de Pós-Graduação da Faculdade de Arquitetura e Urbanismo da UnB, em 2012, na condição de aluna especial, ministrada pelo professor Rômulo José da Costa Ribeiro. Nessa oportunidade, tive o primeiro contato com o assunto, e ao estudá-lo, percebi o quanto ele é crucial para analisar qualquer doença por cartografia e ter uma visão mais ampla do seu comportamento, podendo auxiliar na identificação de áreas de maior risco de adoecimento por meio da geociência.

A referida disciplina foi como uma "semente plantada", que foi se desenvolvendo e ganhando forma até a elaboração de um pré-projeto de pesquisa, a ser desenvolvido no curso de mestrado do Programa de Pós-Graduação em Enfermagem da UnB. O intuito era elaborar uma pesquisa direcionada a compreender a distribuição da tuberculose no Distrito Federal, que tivesse relevância social, que fosse aplicável e que pudesse contribuir para a melhoria da qualidade da assistência ao paciente.

Para divulgação e visibilidade do estudo, os resultados obtidos nesta pesquisa foram apresentados no $67^{\circ}$ Congresso Brasileiro de Enfermagem e no $4^{\circ}$ Colóquio Latino-Americano de História da Enfermagem, São Paulo, em outubro de 2015, na modalidade de apresentação oral. Além disso, foi elaborado um artigo científico, que foi submetido para a revista The Scientific World Journal, estrato B1.

Nessa jornada acadêmico-científica, apresento o trabalho gerado nos próximos capítulos, na expectativa de contribuir para o avanço da ciência em saúde e enfermagem brasileira. 


\section{INTRODUÇÃO}

Como doença de saúde pública, a tuberculose (TB) apresenta elevada morbimortalidade (BRASIL, 2011a; WHO, 2015), é a segunda enfermidade infecciosa mais envolvida com óbito no mundo (WHO, 2015) e afeta particularmente populações de baixa e média renda (LÖNNROTH, et al. 2015). Contudo, países de alta renda têm tido relevante incidência de TB, especialmente ocasionada pela imigração e a resistência às drogas (LÖNNROTH, et al. 2015; WHO, 2015). Em 2014, dados da Organização Mundial de Saúde (OMS) estimaram 9,6 milhões de novos casos de TB e 1,5 milhão de óbitos (WHO, 2015). O Brasil é um dos 22 países de elevada carga de TB no mundo e, em 2014, diagnosticou 82 mil casos, com incidência de 44 casos/100.000 habitantes. e mortalidade de 2,6 casos/100.000 habitantes. (WHO, 2015). O Distrito Federal (DF), unidade federativa do Brasil, situado na região centro- oeste do país, mostrou, em 2013, uma incidência de TB de 12,1 casos/100 mil habitantes., sendo um dos menores dentre as 27 Unidades Federadas (DISTRITO FEDERAL, 2015a).

Locais de baixa incidência de TB como o DF se caracterizam por reduzida transmissão na população geral e os casos são gerados a partir da progressão da infecção latente da TB (ILTB) ao invés da transmissão pessoa a pessoa (BRASIL, 2011a). Existe uma concentração de doentes na área urbana (DE VRIES et al., 2010; DE VRIES et al., 2014), em grupos vulneráveis (pobres, desabrigados, imigrantes) (LÖNNROTH et al., 2009; CRESWELL et al; 2011; ALI, 2014; LÖNNROTH et al., 2014;), pessoas vivendo com HIV/AIDS (ZUMLA et al., 2012), com uso de drogas/fumo/álcool, população privada de liberdade, idosos (UYEMURA, CASTLE, MAKINODAN, 2002), crianças (COLDITZ et al., 1995; SANCHINI et al., 2014) enfermidades crônicas (JEON e MURRAY, 2008), indígenas (TOLLEFSON et al., 2013) e a baixa escolaridade são consideradas causa determinante de TB (STORY et al., 2007). Ou seja, trata-se de grupos de risco onde a doença tem maior probabilidade de ocorrer e onde os serviços de tuberculose devem priorizar suas ações.

Além do estigma e isolamento social (DE VRIES et al., 2010; DIEL, et al.; 2013; DE VRIES et al., 2014; LÖNNROTH et al., 2014; REEVES et al.,, 2014), a sobreposição de vulnerabilidades eventuais, fatores genéticos, (TOLLEFSON et al., 2013), falta de acesso ao setor saúde (STARFIELD, 2002; SOUZA et al., 2015) ou em aderir e responder ao tratamento da TB, agrega maior problema à adesão terapêutica (ALI, 2014; LÖNNROTH, et al. 2015). 
Para um tratamento ser bem-sucedido, deve haver um ponto de entrada de fácil acesso para o serviço de saúde, independentemente do nível de atenção, conhecido como porta de entrada. A ausência de um ponto de entrada do paciente remete a falta de atenção à saúde, uma vez que os sujeitos não obtêm o atendimento de sua demanda ou até mesmo adia esse cuidado (STARFIELD, 2002). Neste sentido, SOUZA et al. (2015) considerou adequado o acesso ao doente de TB, quando a distância entre o domicílio e a unidade de tratamento for de até 800 metros.

A população do Distrito Federal (DF) é fruto do processo de consolidação da criação de Brasília, formada pelo fluxo migratório do período da construção da capital até os dias atuais. Em função da intensa migração, houve um rápido crescimento urbano ocasionando o aumento do número das regiões administrativas; em consequência deste processo, torna-se visível uma das características do DF, a segregação espacial. A população migrante de baixa renda não consegue se fixar no espaço urbano de Brasília e/ou no território do Distrito Federal, sendo então direcionada para outras áreas mais distantes e com infraestrutura precária (IPEA, 2013). É nesse contexto que se estabelecem os núcleos populacionais, as chamadas cidades satélites e, atualmente, denominadas Regiões Administrativas.

Estudo de Styblo et al. (1969) mostrou que os casos de TB aumentaram nas situações de privação e de aglomerados, como durante a guerra ou no pós-guerra. O fato é que a condição de habitação do doente com TB, permite estimar, em condições naturais, sem tratamento, a infecção de 5 a 10 pessoas por ano, e que a pessoa permanece infecciosa durante pelo menos 2 anos após a doença. A estimativa do risco de infecção tuberculosa foi cerca de 10 a 20 indivíduos entre os contatos de cada pessoa com a doença infecciosa, durante o adoecimento e sem tratamento (ROUILLON; PERDRIZET; PARROT, 1976).

Neste sentido, surge o conceito de vulnerabilidade, especialmente, após a década de 1980, em virtude da epidemia de HIV/Aids, com a função de compreender as mudanças das práticas de saúde, da prevenção até a promoção da saúde (CZERESNIA e DE FREITAS, 2009). O termo "vulnerabilidade" então abrange elementos que vão além da ação patogênica de um microrganismo, mas apresenta uma percepção ampliada e reflexiva dos motivos do adoecimento e seus impactos desde as suscetibilidades orgânicas, a estrutura de programas de saúde, passando por aspectos comportamentais, culturais, econômicos e políticos (CZERESNIA e DE FREITAS, 2009). O nível socioeconômico, a ocupação e a nacionalidade também se relacionam à vulnerabilidade, pois esses aspectos tem influenciado sobre o acesso à 
informação, aos serviços e à disponibilidade de recursos, potencializando ou diminuindo a vulnerabilidade a determinado agravo à saúde (SÁNCHEZ e BERTOLOZZI, 2007). Ou seja, vulnerabilidade é a possibilidade de exposição das pessoas a certos agravos ou situações de risco, não ligado a aspectos individuais, mas também coletivos e contextuais, que levam a uma maior ou menor predisposição ao adoecimento, e isso depende da obtenção ou não, da maior ou menor disponibilidade de recursos (CZERESNIA e DE FREITAS, 2009). Assim, entendese que os determinantes sociais predizem a questão do adoecimento da TB e o setor saúde isoladamente, por meio do tratamento da doença, é incapaz de dar resposta a esse problema grave de saúde pública.

Enfim, a doença tuberculosa tem nos determinantes sociais um peso na questão do adoecimento da TB, o foco tem sido até então na busca dos doentes, principalmente, bacilíferos, estimulado pelo aumento no número de casos de TB e sua disseminação na comunidade. Neste sentido, a incidência na maior parte se dá entre os grupos desfavorecidos, como os de baixa renda, pobreza e os desprovidos de adequada alimentação, como também com baixo índice de desenvolvimento humano, o que mostra a necessidade de valorizar os determinantes sociais na eliminação da doença. Segundo a Commission on Social Determinants of Health - CSDH (2007), os determinantes estruturais da saúde são condicionantes que geram ou reforçam a estratificação social na sociedade, que por sua vez é a responsável pela distribuição desigual dos determinantes sociais, elevados níveis de mobilidade populacional e urbanização desordenada e crescimento da população (HARGREAVES, et al., 2011). Contribuem, portanto, para o desenvolvimento da TB, a má ventilação e os grandes aglomerados urbanos, estrutura dos locais de trabalho, ou seja, estrutura espacial, bem como em grupos específicos de moradores de rua, população privada de liberdade, entre outros. (HARGREAVES, et al., 2011).

Uma pesquisa realizada em São Paulo, em 2004, verificou vulnerabilidade da tuberculose na perspectiva do doente e dos profissionais de saúde. Para os pacientes, a vulnerabilidade foi relacionada ao preconceito provocado pela doença e aos problemas sociais por eles vividos, como baixa renda, pobreza, além de pouco conhecimento a respeito da doença e a dificuldade de deslocamento até a unidade para realizar o tratamento da tuberculose. Enquanto isso, na visão dos profissionais, observou-se que foi imputada a culpa da falta de adesão ou abandono do tratamento ao doente, na justificativa de considerarem o paciente desinteressado e responsável pelo insucesso da terapêutica empregada pela equipe (CAMPINAS e ALMEIDA, 2004). Embora fortemente associada com as condições socioeconômicas desfavoráveis, o desconhecimento sobre a tuberculose e a propagação de 
desinformação, os mitos e os estereótipos têm sido apontados como possíveis fatores associados com a vulnerabilidade à doença (SÁNCHEZ, BERTOLO, 2007; MUSSI, TRALDI, TALARICO, 2012). Então, diante deste cenário, a pessoa com tuberculose se encontra exposta a vulnerabilidades que ultrapassam os aspectos patológicos da doença, indo além dos problemas de ordem social, econômica e educacional, imposta pela doença ao enfermo e seguida por segregação social.

Apesar do baixo cenário da TB no DF e a tendência à pré-eliminação, esse fato requer uma compreensão de como se dá a distribuição espacial dos casos de tuberculose para identificar os locais de maior adoecimento, considerando o local de residência do doente, o acesso dele às unidades de saúde para realização do tratamento de TB em seu território e sua relação com a cura da enfermidade. Portanto, para responder aos questionamentos do estudo, torna-se mister identificar geograficamente os bolsões com pessoas doentes de TB para instituir o controle de seus contatos; estabelecer medidas de intervenção precoce que possam eliminar as fontes de infecção tuberculosa; conhecer os serviços de saúde que realizam o tratamento da TB e a distância percorrida pelos pacientes para realizar o tratamento no Sistema Único de Saúde (SUS); subsidiar gestores na criação de estratégias de atuação nas áreas de maior risco, com concentração de esforços para reduzir o sofrimento das pessoas afetadas e custos financeiros, otimizar recursos humanos e laboratoriais para o diagnóstico e tratamento de TB, além de apoio logístico para alcançar a pré-eliminação da doença no Distrito Federal. 


\section{OBJETIVOS}

\section{$2.1 \quad$ OBJETIVO GERAL}

- Analisar espacialmente os casos novos de tuberculose por Regional de Saúde do Distrito Federal, no período de 2003 a 2012.

\subsection{OBJETIVOS ESPECÍFICOS}

- Analisar o perfil sóciodemográfico dos casos novos de tuberculose e sua associação com os determinantes sociais.

- Identificar as regionais de saúde de maior risco de infeção da tuberculose, por meio da espacialização.

- Analisar o acesso aos serviços de saúde e cura, considerando a distância entre o local de residência e a unidades de tratamento da doença. 


\section{REVISÃO DA LITERATURA}

\subsection{EPIDEMIOLOGIA DA TUBERCULOSE}

De acordo com a Organização Mundial de Saúde, no ano de 2014, a população mundial foi estimada em 7,2 bilhões de pessoas, sendo que a incidência de TB foi de aproximadamente 9,6 milhões de casos, cerca de 133 casos para cada 100.000 habitantes. Além disso, o número de casos foi maior na população masculina, correspondendo a 56,3\% dos casos (5,4 milhões). Em relação à taxa de mortalidade, os dados apontaram 16 pessoas para cada 100.000 habitantes, em indivíduos HIV negativos (WHO, 2015).

O Brasil, em 2014, apresentou uma incidência de 44 casos por 100.000 habitantes e mortalidade de 2,6 casos para cada 100.000 pessoas (WHO, 2015). O Distrito Federal, unidade federativa do Brasil, possui uma das menores incidências de tuberculose do país em 2014 com uma taxa de 11,7 casos por 100.000 habitantes e mortalidade de 0,7 casos para cada 100.000 habitantes (BRASIL, 2015).

\subsection{ASPECTOS GERAIS DA TUBERCULOSE}

A tuberculose (TB) é um problema de saúde mundial dado o elevado número de casos e mortes dessa enfermidade, porém é inaceitável em virtude de ser uma doença curável com diagnóstico e tratamento fácil (WHO, 2015). Trata-se de uma doença infecciosa causada por um Mycobacterium tuberculosis (MTB) ou Bacilo de Koch, que afeta principalmente os pulmões, órgãos e/ou sistemas (BRASIL, 2011a).

\subsubsection{Formas clínicas}

Quanto à forma clínica, a doença se apresenta na forma pulmonar, extrapulmonar e a pulmonar-extrapulmonar (BRASIL, 2005). 


\subsubsection{Tuberculose pulmonar}

A tuberculose pulmonar é a forma mais frequente e relevante para a saúde pública, uma vez que é a responsável pela manutenção da cadeia de transmissão da doença quando apresenta a forma bacilífera ${ }^{1}$. Os bacilíferos que apresentam baciloscopia de escarro positiva são a principal fonte de infecção, já os que apresentam baciloscopia negativa são menos eficientes como fontes de transmissão. A contaminação ocorre de forma direta de pessoa a pessoa ao falar, tossir ou espirrar (BRASIL 2005; BRASIL, 2011a).

A TB pulmonar pode se manifestar sob três formas: primária, pós-primária (ou secundária) ou miliar. Os sintomas da TB pulmonar consistem em tosse persistente, produtiva ou não (com muco e eventualmente sangue), febre vespertina, sudorese noturna e emagrecimento (BRASIL 2005; BRASIL, 2011a).

A TB pulmonar primária é a mais comum em crianças e clinicamente apresenta-se, na maior parte das vezes, de forma insidiosa. O paciente apresenta irritação, febre baixa, sudorese noturna, inapetência e o exame físico pode ser irrelevante (BRASIL, 2005; BRASIL, 2011a).

A TB pulmonar pós-primária pode ocorrer em qualquer idade, mas é mais comum no adolescente e no adulto jovem. A sintomatologia específica consiste em tosse, seca ou produtiva. Em locais com elevadas taxas de incidência de TB, todo paciente que procura a unidade de saúde devido à tosse deve ter a TB incluída na sua investigação diagnóstica (BRASIL, 2005; BRASIL, 2011a). A TB miliar é uma forma grave de doença e ocorre em 1,0\% dos casos de TB em pacientes HIV soronegativos e em até $10 \%$ dos casos em pacientes HIV soropositivos, em fase avançada de imunossupressão. É mais comum em crianças e em adultos jovens. Os sintomas são febre, astenia e emagrecimento, que, em associação com tosse, ocorrem em 80\% dos casos (BRASIL 2005; BRASIL, 2011a).

${ }^{1}$ É considerada tuberculose pulmonar bacilífera quando o paciente apresenta duas baciloscopias diretas positivas ou uma baciloscopia direta positiva e cultura positiva ou uma baciloscopia direta positiva e imagem radiológica sugestiva de tuberculose (BRASIL, 2005). 


\subsubsection{Tuberculose extrapulmonar}

As manifestações extrapulmonares da TB têm seus sinais e sintomas dependentes dos órgãos e/ou sistemas acometidos. Sua ocorrência aumenta entre pacientes com AIDS, especialmente entre aqueles com imunocomprometimento grave. As principais formas diagnosticadas compreendem tuberculose pleural, ganglionar periférica, meningoencefálica, pericárdica e óssea (BRASIL, 2011a).

Considerando a tuberculose pleural, podemos afirmar que ela é a mais comum entre as extrapulmonares para indivíduos HIV soronegativos. Ocorre mais em jovens e costuma apresentar emagrecimento, anorexia $(70 \%$ dos casos) e febre com tosse seca $(60 \%)$. Casualmente, pode mimetizar uma pneumonia bacteriana aguda, e a dispneia pode surgir apenas nos casos com maior tempo de evolução dos sintomas. A cultura, associada ao exame histopatológico do fragmento pleural, permite o diagnóstico em até $90 \%$ casos (BRASIL, 2011a).

A TB ganglionar periférica, por sua vez, é a forma mais frequente de TB extrapulmonar em pacientes HIV soropositivos e crianças, sendo mais frequente abaixo dos 40 anos. Ao exame físico, os gânglios podem apresentar-se endurecidos ou amolecidos, aderentes entre si e profundos, podendo evoluir para uma inflamação da pele em anexo. $\mathrm{O}$ diagnóstico é adquirido por meio de aspirado e/ou biópsia ganglionar, para realização de exames bacteriológicos e histopatológicos (BRASIL, 2011a).

A TB meningoencefálica é responsável por 3,0\% dos casos em pacientes HIV soronegativos e por até $10 \%$ dos casos em pacientes HIV soropositivos. A manifestação mais comum é a meningite basal exsudativa, sendo mais frequente em crianças abaixo dos 6 anos de idade. Clinicamente, pode ser subaguda ou crônica e possui sinais e sintomas com duração superior a quatro semanas (BRASIL, 2011a).

Em relação à tuberculose pericárdica, seu aparecimento clínico é subagudo e usualmente não se associa à TB pulmonar, embora possa ocorrer conjuntamente com TB pleural. Os principais sintomas são dor torácica, tosse seca e dispneia (BRASIL, 2011a).

A TB óssea é a mais comum em crianças (10\% a 20\%) ou em pessoas com quarenta ou cinquenta anos. Atinge mais a coluna vertebral e as articulações coxofemoral e do joelho, apesar de ocorrer em outros locais. A TB de coluna (mal de Pott) é responsável por 1,0\% de todos os 
casos de TB e até 50\% de todos os casos de TB óssea. O quadro clínico consiste em dor lombar, dor à palpação e sudorese noturna (BRASIL, 2011a).

\subsubsection{Pulmonar + extrapulmonar}

O doente de TB poderá apresentar concomitantemente a forma pulmonar e extrapulmonar. Um paciente tanto com TB pulmonar quanto extrapulmonar deve ser classificado como um caso de tuberculose pulmonar (WHO, 2013). As formas exclusivamente extrapulmonares não transmitem a doença (BRASIL, 2011a).

\subsubsection{Identificação do suspeito de TB}

A busca ativa de sintomáticos respiratórios (SR), indivíduos com tosse por tempo igual ou superior a três semanas, é uma atividade de saúde pública, capaz de identificar precocemente casos suspeitos de tuberculose (BRASIL, 2015).

A busca ativa do SR deve ser feita em todos os níveis de atenção (primário, secundário e terciário), de forma permanente, sendo uma estratégia orientada internacionalmente pela Organização Mundial de Saúde (BRASIL, 2011a; WHO, 2015). Com a busca ativa é possível identificar precocemente os casos bacilíferos, interromper a cadeia de transmissão e reduzir a incidência da enfermidade a longo prazo (BRASIL, 2015).

A busca ativa apresenta métodos importantes para a identificação do SR como a Estratégia Saúde da Família - ESF, Programa de Agente Comunitário de Saúde - Pacs, bem como deve ter o envolvimento dos hospitais gerais e de emergência (BRASIL, 2015).

\subsubsection{Diagnóstico da tuberculose}

Várias tecnologias podem ser utilizadas para o diagnóstico de TB, a saber:

\subsubsection{Bacteriológica}

A pesquisa bacteriológica é utilizada tanto para o diagnóstico quanto para o controle do tratamento e cura. A pesquisa do bacilo álcool-ácido resistente - BAAR, pelo método de ZiehlNielsen, é a técnica mais utilizada em nosso meio. A baciloscopia do escarro permite detectar 
de $60 \%$ a $80 \%$ dos casos de tuberculose pulmonar, sendo que é o que confirma o diagnóstico e é indicada para todos os sintomáticos respiratórios. (BRASIL, 2005; BRASIL, 2011a).

\subsubsection{Cultura para BK}

A cultura de escarro ou de outras secreções está indicada para suspeitos da doença pulmonar e negativos ao exame direto do escarro, bem como para o diagnóstico de formas extrapulmonares (como meníngea, renal, pleural, óssea e ganglionar) e diagnóstico de tuberculose em paciente soropositivo para o HIV/Aids. A cultura é também indicada nos casos de suspeita de resistência bacteriana às drogas, acompanhada do teste de sensibilidade, nos casos de retratamento após falência bacteriológica ao esquema de tratamento padrão - RHZ ou recidiva da doença ou reinício após abandono (BRASIL 2005 e BRASIL, 2011a).

Nos casos pulmonares com baciloscopia negativa, a cultura do escarro pode aumentar em até 30\% o diagnóstico bacteriológico da doença (BRASIL 2005 e BRASIL, 2011).

Contudo, o único método diagnóstico capaz de confirmar a infecção por TB é a cultura seguida da confirmação da espécie $M$. tuberculosis por testes bioquímicos ou moleculares (BRASIL, 2011a).

\subsubsection{Exame radiológico}

A radiografia de tórax é importante auxiliar no diagnóstico, trata-se de um método utilizado na investigação da tuberculose que indica uma suspeita de doença em atividade ou doença no passado, além do tipo e extensão do comprometimento pulmonar ocorrido (BURRIL, 2007; DALEY, GOTWAY e JASMER, 2011).

A radiografia deve ser solicitada para todo o paciente com suspeita clínica de TB pulmonar. Ainda assim, até $15 \%$ dos casos de TB pulmonar não apresentam alterações radiológicas, principalmente pacientes imunodeprimidos (BRASIL, 2005 e BRASIL, 2011a).

\subsubsection{Prova tuberculínica}

A prova tuberculínica (PT) é indicada como método auxiliar em pessoas que não foram vacinadas com BCG (Bacilo de Calmette-Guérin). A PT consiste na inoculação intradérmica de um derivado protéico do $M$. tuberculosis para verificar a resposta imune celular a estes 
antígenos. No Brasil, a tuberculina usada é o PPD-RT 23, aplicada por via intradérmica no terço médio da face anterior do antebraço esquerdo, na dose de $0,1 \mathrm{ml}$, que contém $2 \mathrm{UT}$ - unidades de tuberculina.

A leitura da prova tuberculínica, feita por profissional treinado, deve ser realizada 48 a 72 horas após a aplicação, estendendo-se para até 96 horas, caso o paciente se ausente para a leitura na data marcada. O resultado da PT deve ser descrito em milímetros. É considerado como infectado pelo $M$. tuberculosis o paciente que tiver enduração igual ou superior a $5 \mathrm{~mm}$ (BRASIL, 2005; BRASIL, 2011a; BRASIL, 2014a).

Reações falso-positivas podem acontecer em pessoas infectadas por outras micobactérias ou vacinadas com a BCG, principalmente se vacinadas (ou revacinadas) após o primeiro ano de vida. Em geral, essas reações da BCG são maiores e duradouras. Porém, a reação tende a diminuir com o passar do tempo e se a PT for realizada dez anos ou mais após a última vacinação, o efeito da BCG sobre ela poderá ser mínimo (BRASIL, 2011a).

\subsubsection{Testes IGRAs}

Os testes IGRA - Interferon Gamma Release Assay - são capazes de identificar as proteínas imunogênicas das micobactérias ESAT-6, CFP-10 e TB 7.7. Ou seja, trata-se de testes imunológicos, cuja função é auxiliar no diagnóstico da TB latente em populações vacinadas com BCG. O princípio dos testes é a verificação dos níveis in vitro do interferon gama produzido por células T que tenham sido estimuladas por antígenos de TB.

Há dois tipos de testes IGRA, o Quantiferon gold (Cellestis) e o TSPOT-TB (Oxfordimmunotech). Eles analisam a produção de interferão gama (INF-y) por uma técnica de ELISA (quantiferon) ou ELISPOT (TSPOT-TB), em resposta à estimulação por antígenos específicos de Mtb (PAI, RILEY e COLFORD, 2004; RODRIGUES, 2013).

Os testes IGRA apresentam algumas vantagens, necessitam apenas de uma amostra humana sanguínea simples, não é preciso que o paciente retorne ao serviço para interpretação do exame, não é influenciado pela vacinação prévia de BCG ou infecção por outras micobactérias e são mais específicos quando comparado à PT (MACHADO, 2014). 


\subsubsection{Histopatológico}

O diagnóstico histopatológico é aplicado nas formas extrapulmonares, ou pulmonares por biópsia que se apresentam radiologicamente como doença difusa, por exemplo, na TB miliar ou em pacientes imunossuprimidos (BRASIL, 2011a).

\subsubsection{Reação em cadeia da polimerase (PCR)}

A reação em cadeia da polimerase (PCR) é utilizada para detecção de sequências nucleotídeas específicas dos microrganismos. O custo da PCR na rotina é factível, considerando que o diagnóstico rápido em pacientes paucibacilares permite instituir o tratamento específico o mais precocemente possível, diminuindo assim as fontes bacilíferas e, com elas, a infecção pelo M. tuberculosis, portanto reduzindo a cadeia de transmissão. O desenvolvimento e a padronização, próprios para o teste, tornam seu custo mais acessível, tendo em vista que essa tecnologia deve ser reservada para centros de referência na investigação de casos que demandem diagnóstico rápido.

\subsubsection{Outros exames}

A broncoscopia e os procedimentos a ela associados podem colaborar no diagnóstico da tuberculose para as formas negativas à baciloscopia, suspeita de outra doença pulmonar, presença de doença que acomete difusamente o parênquima pulmonar, suspeita de tuberculose endobrônquica ou em pacientes imunodeprimidos, particularmente os infectados pelo HIV (BRASIL, 2005).

Outras tecnologias como tomografia computadorizada de alta resolução (TCAR), ressonância magnética $(\mathrm{RM})$ e tomografia com emissão de pósitrons (PET) são utilizadas para o diagnóstico de TB ativa e latente e podem auxiliar no diagnóstico de tuberculose pulmonar atípica ou extrapulmonar, frequente em pacientes infectados pelo HIV (BRASIL, 2011a).

\subsubsection{Estratégia de adesão ao tratamento de TB}

A tuberculose é uma doença grave, mas curável em quase 100\% dos casos novos, que são pessoas não submetidas ao tratamento antiTB ou o fizeram por até 30 dias ou a mais de cinco anos de tratamento. Para um tratamento de qualidade e um acompanhamento adequado, foi desenvolvido o Tratamento Diretamente Observado - TDO, onde o profissional treinado 
passa a observar a tomada da medicação do paciente desde o início do tratamento até a sua cura. O tratamento da tuberculose deve ser feito em regime ambulatorial, supervisionado, no serviço de saúde mais próximo, na residência ou no trabalho do doente (BRASIL, 2005; BRASIL, 2011).

A escolha do regime de TDO deve ser decididoconjuntamente entre a equipe de saúde e o paciente, considerando a realidade local e a estrutura de atenção à saúde existente. É desejável que a tomada do medicamento seja de observação diária, de segunda a sexta-feira. Para o sucesso do TDO é preciso estabelecer um elo entre o doente, o profissional e o serviço de saúde. É importante retirar as barreiras que impedem a adesão, utilizando estratégias de reabilitação social, melhora da autoestima, qualificação profissional e outras demandas de atendimento sociais (BRASIL, 2005; BRASIL, 2011b).

\subsubsection{Tratamento da tuberculose}

A combinação entre medicação apropriada, doses corretas e o uso por tempo suficiente são os princípios básicos para o tratamento, impossibilitando a persistência bacteriana e a resistência aos medicamentos, possibilitando assim atingir a cura. Daí, para cumprir esses princípios há a necessidade do uso de estratégias do TDO para obter sucesso no tratamento (BRASIL, 2011b). Outra coisa de fundamental importância é que, uma vez iniciado o tratamento, ele não deve ser interrompido, salvo após uma exaustiva revisão clínica e laboratorial que determine modificações no diagnóstico ou no esquema terapêutico (LOPES, 2015).

O tratamento da TB é feito com quatro drogas simultâneas a fim de evitar a seleção de bacilos resistentes, visto que bacilos naturalmente resistentes a um medicamento podem ser sensíveis a outro (BRASIL, 2011a). As drogas padronizadas pelo Ministério de Saúde e utilizadas no esquema terapêutico básico são: Isoniazida - H; Rifampicina - R; Pirazinamida Z; Etambutol - E. A Etionamida - Et e Estreptomicina - S são utilizadas em situações específicas. Os fármacos $\mathrm{H}$ e $\mathrm{R}$ são os medicamentos de maior poder bactericida; $\mathrm{R}$ é o medicamento com maior poder esterilizante; $\mathrm{Z}$ e $\mathrm{S}$ também são bactericidas contra algumas colônias de bacilos; $\mathrm{Z}$ é ativa apenas em meio ácido (intracelular ou no interior dos granulomas); S é bactericida contra os bacilos de multiplicação rápida. $\mathrm{O}$ E é bacteriostático e utilizado em associação com drogas mais potentes para prevenir a emergência de bacilos resistentes (BRASIL, 2011a). 
O esquema básico terapêutico consiste em duas fases para o tratamento da $\mathrm{TB}$ em adultos e adolescentes: dois meses de RHZE (fase intensiva) e quatro meses de RH (fase de manutenção). O esquema básico para o tratamento da TB em crianças ( $<10$ anos) consiste em dois meses de RHZ (fase intensiva) e quatro meses de RH (fase de manutenção). O esquema para o tratamento da TB meningoencefálica em adultos e adolescentes baseia-se em dois meses de RHZE (fase intensa) e sete meses de RH (fase de manutenção) (BRASIL, 2011a).

Os medicamentos devem ser administrados em uma única tomada e preferencialmente em jejum (uma a duas horas após o café da manhã). O tratamento das formas extrapulmonares, exceto a meningoencefálica, terá duração de seis meses, assim como o tratamento dos pacientes coinfectados com HIV, independentemente da fase de evolução da infecção viral (BRASIL, 2011a).

\subsubsection{A imunologia na tuberculose}

O Mycobacterium tuberculosis (Mtb) é uma bactéria intracelular facultativa, aeróbia obrigatória, de crescimento demorado, que pode se multiplicar dentro de macrófagos e em outras células. Essa bactéria tem a capacidade de permanecer viva por anos e se multiplicar quando o sistema imunológico apresentar falência. A sequência do seu genoma apresenta aproximadamente 376 proteínas especificas para a espécie, daí a sua virulência e a complexidade das reações imunológicas ocorrem, o que também amplia os horizontes para a criação de novos métodos diagnósticos e de controle da TB (NORTH; JUNG, 2004; MOUTINHO, 2011).

O sistema imunológico humano mediado por linfócitos T e macrófagos para o controle do Mtb, apresenta eventos que incluem a expressão de citocinas antimicobacterianas como o IFN- $\gamma$ e o FNT- $\alpha$, a produção dos óxidos tóxicos derivados do nitrogênio e a lise no fagolisossomo. O Mtb é capaz de escapar dos mecanismos de defesa e permanecer vivo dentro do granuloma em quase um terço da população (ALMEIDA et al., 2005).

Os mais relevantes dispositivos de escape do Mtb envolvem a elaboração de moléculas como o ESAT-6, capaz de impedir a produção do IL-12 e IFN-y. O impedimento tanto a apoptose de macrófagos infectados e quanto da fusão do fagócito ao lisossomo favorece a sobrevida e a multiplicação dos bacilos no interior do fagócito. A lipoproteína 19KDa e derivados lipídicos do Mtb comunicam-se com TLR2 (receptor de superfície celular nos 
fagócitos e outras células, apto para reconhecer estruturas microbianas) e, unidos, induzem a resposta predominantemente inflamatória encontrada na TB. A sinalização via TLR2 em resposta ao Mtb, porém, aumenta a secreção de IL-10, citocina Th2, pelas células dendríticas e macrófagos, o que sugere o envolvimento de mecanismo micobacteriano controlador da resposta inflamatória no hospedeiro (SALGAME, 2005; MOUTINHO, 2011).

A latência é a maior barreira para a eliminação da infecção pelo Mtb. Estudos demostraram que a imunidade antiMtb é mensurada especialmente por linfócitos TCD4+ e TCD8+ do tipo Th1. As células TCD4+ desempenham a principal função na resposta à micobactéria. Em média, 20 dias são o suficiente para a produção de IFN- $\gamma$ por linfócitos Th1. Pacientes com mutação recessiva de genes para receptores ligantes de IFN- $\gamma$, a subunidade IL12 p40 e a cadeia $\beta 1$ do receptor de IL-12, e os aidéticos adoecem gravemente quando infectados pelo Mtb, visto que são incapazes de sintetizar IFN- $\gamma$ e outras citocinas Th1, o que impossibilita a formação do granuloma para conter o microrganismo (CHAN, FLYNN, 2004; NORTH, JUNG, 2004).

\subsection{DETERMINANTES SOCIAIS E A TUBERCULOSE}

O risco do adoecimento de tuberculose está associado a vários fatores ligados a determinações sociais, objeto de intensa discussão de inúmeros artigos que tratam da tuberculose como doença da pobreza e miséria. A conceituação de determinantes sociais (DDS) abarcam conteúdos e significados inseridos temporalmente, e segundo Buss e Pellegrini-Filho (2007, p. 78) "são os fatores sociais, econômicos, culturais, étnicos/raciais, psicológicos e comportamentais que influenciam a ocorrência de problemas de saúde e seus fatores de risco na população". Posteriormente, a Organização Mundial da Saúde (OMS) define DSS como as condições sociais em que vivem e trabalham as pessoas. Outros autores caracterizam como um conjunto de fatores e condições sociais que afetam a saúde e que podem ser modificados com ações educativas; e finalmente, a compreensão do contexto social onde a pessoa vive.

Considerando estes aspectos, dois modelos são propostos para a compreensão dos determinantes sociais no adoecimento de pessoas, incluindo a da doença tuberculosa, o modelo de Dahlgren e Whitehead e o de Diderichsen, permitem identificar pontos para intervenções de políticas, no sentido de minimizar os diferenciais de DSS originados pela posição social dos indivíduos e grupos. Estão incluídos nesses modelos desde questões comportamentais e de estilos de vida, isto é, cultura, criação de espaços públicos para a prática de esportes e exercícios 
físicos, bem como o problema do tabaco e álcool. A coesão social e as relações de solidariedade e confiança entre pessoas e grupos se inserem neste contexto, bem como acesso à água limpa, esgoto, habitação e alimentos adequados, emprego, ambientes de trabalho saudáveis, serviços de saúde e educação de qualidade, de forma reduzir a violência, a degradação ambiental e as doenças (BUSS e PELLEGRINI-FILHO, 2007).

O conjunto de fatores ligados à determinação social é vasto, mas nesse estudo realizouse um recorte com indicadores e variáveis que incluiu o sexo, a migração, o tabagismo, o alcoolismo, a escolaridade, a renda, a profissão do lar, a fecundidade, o envelhecimento, a violência e a mortalidade, e descritos mais detalhadamente a seguir:

\subsubsection{A vulnerabilidade no contexto da tuberculose}

O termo vulnerabilidade é empregado em diversas áreas do conhecimento, destacandose as áreas como as ciências da vida, as naturais e as sociais, especialmente área da geografia, demografia, economia, saúde e bioética (SCHUMANN e MOURA, 2015).

O conceito de vulnerabilidade deve ser compreendido como uma conjunção de fatores individuais (biológicos, cognitivo e comportamentais), programáticos (programas de serviços de saúde), sociais, econômicos e culturais que são mutuamente influenciáveis, determinando o grau de susceptibilidade de indivíduos e grupos em relação a questões de saúde. Isto é, a vulnerabilidade pode ser entendida como a condição da pessoa que está à margem do processo social (DINIZ; GUILHEM, 2009; GUILHEM; AZEVEDO, 2009).

O conceito de risco é superado pelo conceito de vulnerabilidade, que tem sido utilizado, na saúde, em caráter probabilístico com o intuito de orientar as atividades de intervenção em saúde. De acordo com Ayres (2001), é preciso alertar sobre a necessidade de rever a relação entre risco e intervenções em saúde, salientando que os "objetos" em saúde são sujeitos (pessoas) e ao utilizar o termo risco e não vulnerabilidade pode provocar estigma social. O conceito de vulnerabilidade é novo e supera o caráter individualizante e probabilístico do antigo conceito de "risco", ao denotar a vulnerabilidade como um conjunto de aspectos que vão além do individual, abrangendo aspectos coletivos, contextuais, que levam à suscetibilidade a doenças ou agravos. A definição de vulnerabilidade leva em conta aspectos que dizem respeito à disponibilidade ou a ausência de recursos destinados à proteção das pessoas. (SÁNCHEZ e BERTOLOZZI, 2007). 
São vários os determinantes ligados ao adoecimento por tuberculose e um deles se encontra intimamente ligado ao sexo; isso significa que homens adoecem mais de TB do que as mulheres (NARASIMHAN, 2013). Na cidade de Pequim, China, um estudo de casocontrole, analisando a relação entre o fumo e a tuberculose, estimou que o tabagismo estivesse presente em 22,5\% dos homens e 6,6\% de mulheres e que foi um fator que contribuiu para as mortes em homens (JIANG et al., 2009).

A associação entre o tabagismo e a incidência de TB mostrou que a mortalidade por tuberculose pulmonar no México foi maior entre os consumidores de 11 ou mais cigarros por dia (BONACCI et al., 2013). Adicionalmente, quando comparados homens e mulheres, estudos têm mostrado que os homens apresentam doenças mais graves e crônicas. Além disso, eles morrem mais prematuramente do que as mulheres (COURTENAY, 2000; NARDI et al., 2007). Os homens não buscam os serviços de saúde com a mesma frequência que as mulheres (FIGUEIREDO, 2005; BRASIL, 2008), daí tratamentos longos, requer esforço adicional para a obtenção da cura (BRASIL, 2008).

De acordo com aspectos levantados pela Política Nacional de Atenção Integral à Saúde do Homem, essa ligação está associada a fatores ou situações de risco como o consumo de álcool e o hábito de fumar (BRASIL, 2008), com impacto no adoecimento por tuberculose (BONACCI et al., 2013; MATSUMOTO, et al., 2012). Além disso, os homens procuram menos os serviços de saúde, daí o baixo acesso e a reduzida procura dessas pessoas aos serviços de saúde (BRASIL, 2008). Segundo dados do Ministério da Saúde (BRASIL, 2008), os homens alegam que os horários, a jornada de trabalho e a demora do atendimento são condições que os afastam da assistência à saúde.

Sobretudo, as referências ressaltam que ocorre uma interação do uso de tabaco associado ao consumo de álcool, assim como a questão da mortalidade e recaída, e são assinaladas a seguir.

No Ceará, uma pesquisa de caso-controle constatou que dentre cinco fatores de risco observados no adoecimento por TB, o alcoolismo e o tabagismo estavam associados ao desenvolvimento da tuberculose resistente à Rifampicina adquirida (TBMR) (BARROSO, et al., 2003). Na Índia, uma pesquisa mostrou que o fator de risco ligado a recaída da TB foi o alcoolismo (AZHAR et al., 2012).

Um estudo proposto por Ferreira, et al., (2005), em hospital de Natal (RN - Brasil), no período de 2000 a 2002, mostrou que o etilismo e o tabagismo foram fatores que contribuíram 
para a internação dos pacientes com tuberculose pulmonar. Dos sujeitos analisados em Natal, 20,6\% alegaram consumo de álcool associado ao cigarro. Em um hospital de Soweto, África do Sul, a prevalência do tabaco em 707 pacientes internados com diagnóstico de tuberculose foi de 26,0\% até dois meses antes do diagnóstico da enfermidade (LAM, et. al., 2013).

Por sua vez, o tabagismo tem envolvimento com as populações de baixa renda (PEDNEKAR e GUPTA 2007). Desde a $1^{\mathrm{a}}$ Guerra Mundial os homens assumiram o hábito de fumar e, a partir daí as dificuldades que comprometem a sua saúde (DAVIES, 2005). Uma pesquisa em Osaka, Japão, apontou que pacientes bacilíferos a prevalência de fumantes com tuberculose foi significativamente maior, bem como os doentes fumantes, apresentaram mais lesões pulmonares cavitárias quando comparadas a doentes que fumavam, mas não tinham tuberculose (MATSUMOTO, et al., 2012). Para Wen et al. (2010), o hábito de fumar pode agravar o estado de saúde de um tuberculoso.

Além disso, variáveis culturais envolvem homens na não-adesão às recomendações de atenção à saúde. Isso denota fragilidade, pelo fato de os homens não poderem vivenciar o adoecimento, o que dificulta a busca pelos serviços de saúde (GOMES, 2003; DE KEIJZER, 2003).

Adicionalmente, dados da Organização Mundial de Saúde mostraram que o alcoolismo representa um problema de Saúde Pública, sendo uma das causas de óbitos nos homens, alcançando 7,6\% de mortes, em relação a 4,0\% das mulheres (WHO, 2015). Homens e mulheres consomem bebidas alcóolicas em frequências diferentes, os homens iniciam precocemente o consumo de álcool, tendem a ingerir maior quantitativo e daí a ocorrência de mais danos à saúde do que nas mulheres (BRASIL, 2008).

Outro grupo de vulnerabilidade à tuberculose são os idosos e, de acordo com a Política Nacional do Idoso, entende-se por pessoa idosa a pessoa com 60 anos ou mais, seguindo-se critérios demográficos nacionais e internacionais (BRASIL, 2010). O envelhecimento e a tuberculose têm uma forte correlação, em função dos aspectos imunológicos, e isso leva a uma maior predisposição a tuberculose. (SCHEREINER, 1993; CHAIMOWICZ, 2001).

Hosford et al., (2015) assinalaram que idosos têm maiores coeficientes de tuberculose (TB) nos Estados Unidos em comparação com outros grupos e mostram pior prognóstico da doença (KAWATSU e ISHIKA, 2014; ROWIŃSKA-ZAKRZEWSKA et al., 2016). 
Outro aspecto importante no idoso é a associação dessa enfermidade com patologias crônicas como a diabetes, doenças cardiovasculares e pulmonares (MACIEL et al, 2010). De acordo com Uyemura, Castle e Makinodan (2002) e Storla et al.,(2008), ser idoso é um fator de risco para o desenvolvimento de tuberculose, especialmente devido ao atraso ou dificuldade em promover o diagnóstico de TB e ou dar seguimento ao tratamento. Na Etiópia, um estudo desenvolvido por Yimer, Bjune e Alene (2005) observou que pessoas idosas são dependentes de outras pessoas, o que pode gerar dificuldade na identificação dos sintomas de TB e atraso no diagnóstico de tratamento desse agravo.

Dentre os fatores associados à porta de entrada do sistema de saúde no diagnóstico da TB em pessoas idosas e as recomendações tratam de orientar a melhoria dos serviços da atenção primária à saúde para combater o retardo do diagnóstico da TB nesse grupo (SÁ-SILVA, et al., 2015).

A forma pulmonar é mais presente em idosos e suas características clínicas em adultos idosos, além de atípicas, são confundidas com outras doenças relacionadas a essa idade, por isso o seu diagnóstico e tratamento no idoso podem ser difíceis e a terapêutica adotada pode provocar reações adversas pelos medicamentos (RAJAGOPALAN, 2016). Quanto à sintomatologia do idoso, eles podem não apresentar as características clínicas clássicas da TB, tais como febre, suores noturnos ou hemoptise, mas apresentam manifestações clínicas sutis de perda de apetite, declínio funcional e febre baixa. Por sua vez, o envelhecimento é uma das principais causas de morte entre os pacientes com tuberculose (RAJAGOPALAN, 2016; (TUBERCULOSIS SURVEILLANCE CENTER, 2016).

A violência é outro indicador social utilizado para avaliar a vulnerabilidade entre os doentes de tuberculose. Uma pesquisa realizada no Rio de Janeiro, em 2012, detectou que a maior parte dos entrevistados com TB morava em locais com registro de elevada violência social. Isto é, esses doentes de tuberculose residiam em áreas controladas pelos traficantes de drogas, os quais impediam a livre circulação de moradores e de pessoas fora do território de atuação do tráfico e região (SILVA; SOUSA; SANT'ANNA, 2014). Também, um estudo realizado em Porto Alegre identificou que $40 \%$ dos óbitos da cidade foram por homicídios e a maioria das vítimas proviam de áreas menos favorecidos da população (ACOSTA; BASSANESI, 2014), sendo estes locais o foco da doença tuberculosa. Isso denota que a violência dificulta o acesso dos profissionais de saúde e dos usuários, na busca de um diagnóstico nos serviços de saúde, inclusive de tuberculose, uma vez que se trata de um local hostil de busca de assistência. 
A violência é um fenômeno difuso, complexo, ligado a várias causas, com raízes em fatores sociais, culturais, políticos e econômicos (BRASIL, 2008). As Políticas macroeconômicas e o mercado de trabalho podem contribuir para a redução da violência e, consequentemente, contribuir também para redução da tuberculose (BUSS; PELLEGRINI FILHO, 2007).

A tuberculose é a segunda enfermidade infecciosa mais envolvida com o óbito (WHO, 2015), afetando mais populações de baixa e média renda (LÖNNROTH et al., 2015). Um estudo aplicado na África evidenciou que a mortalidade precoce estava aliada a doenças oportunistas como a tuberculose e demais síndromes, como causa de morte mais comum naquele continente (GUPTA et al., 2011).

Kawatsu, Ishikawa (2014), em revisão sistemática sobre a associação da mortalidade por tuberculose e fatores socioeconômicos, mostraram que o desemprego, a educação, desabrigados, o abuso de álcool e a nacionalidade são fatores de risco para óbito por TB. Certamente, muitos desses fatores são marcadores de pobreza e no Japão também, onde a vulnerabilidade socioeconômica tem sido sugerida a influência sobre a morte em tuberculose.

Uma revisão sistemática entre as pessoas que vivem com HIV, realizada por Ford et al. (2016), identificou que a maioria das internações dos adultos foram ocasionadas por TB, ou seja, a principal causa de hospitalização.

Mesmo frente à luta contra a tuberculose, observou-se alguns avanços, entre eles a mortalidade de TB, que registra queda entre 1999 e 2014, embora 1,5 milhão de pessoas morreram de TB em 2014 e a maioria dessas mortes poderia ter sido evitada (WHO, 2015). A Estratégia Fim da TB foi aderida por todos os estados-membros da Organização Mundial de Saúde (OMS), e o Brasil é um deles, tendo como diretriz a redução da incidência de TB em $80 \%$ e a mortalidade em $90 \%$, o que se espera eliminar os enormes custos para as unidades que tratam TB até 2030 (WHO, 2015).

A expectativa de vida vem aumentando com o tempo e, consequentemente, o número de idosos. Ao contrário do que se imagina, o processo de envelhecimento populacional resulta da queda da fecundidade (número de filhos por mulher em idade fértil) e não do declínio da mortalidade. Uma população torna-se mais idosa à medida que aumenta a proporção das pessoas de maior idade e diminui a proporção de indivíduos mais jovens, ou seja, uma determinada população só envelhece se houver cada vez mais, uma menor taxa de fecundidade (NASRI, 2008). 
A transição demográfica originou-se na Europa e seu primeiro fenômeno foi a diminuição da fecundidade, observada na Revolução Industrial, onde as mulheres começaram a ingressar no mercado de trabalho e passaram a ter menos filhos. Outro fato observado após a Revolução Industrial foi o surgimento da pílula anticoncepcional, que contribuiu para a redução do número de filhos. $\mathrm{O}$ aumento na expectativa de vida ocorreu de modo insidioso e lento e foi possível graças às melhores condições sociais e de saneamento, além do uso de antibióticos e vacinas (DE CARVALHO e RODRÍGUEZ-WONG, 2008; NASRI, 2008).

Entretanto, o crescimento populacional desordenado e a concentração de pessoas nas periferias dos grandes centros urbanos vêm se arrastando ao longo dos anos. Em função disso, o aumento da população nesses aglomerados é maior e tem relação com indicadores de status socioeconômicos, pobreza e desemprego. Neste sentido, nesses nichos populacionais a fecundidade ainda é expressiva (BUSS; PELLEGRINI FILHO, 2007), e está inserida no contexto da tuberculose, ao contrário, das áreas de melhor poder aquisitivo e de saneamento.

Outro aspecto da determinação social que está fortemente associado à saúde das pessoas é a renda. As diferenças de renda influenciam a qualidade de saúde pela limitação de recursos dos indivíduos e ausência de investimentos na educação, transporte, saneamento, habitação e serviços de saúde, decorrentes de processos econômicos e políticos (BUSS; PELLEGRINI FILHO, 2007).

Países com fragilidades sociais, ocasionadas pelas disparidades de renda, são os que menos investem em capital humano e em redes de apoio social, essenciais para a promoção e proteção da saúde individual e da coletividade (LÖNNROTH et al., 2015). Estudos europeus mostraram que a pobreza coloca as pessoas em maior risco de desenvolver tuberculose (UYEMURA; CASTLE; MAKINODAN, 2002), diferentemente do que ocorre em países de alta renda (Alemanha, Austrália, Estados Unidos, Canadá, Espanha, entre outros), onde a incidência da tuberculose reduziu rapidamente (DYE, 2009; WHO, 2015).

A baixa escolaridade é uma das marcas da pobreza e exclusão, comum em áreas de tuberculose. No Brasil, pesquisa realizada por Teixeira e Costa (2011) confirmou essa relação entre o nível educacional e o risco de desenvolver a doença tuberculosa. Hargreaves et al. (2011) e De Vries et al. (2014) assinalaram que a rápida urbanização e o crescimento populacional dão origem a vulnerabilidade, especialmente, em locais de baixa escolaridade. Aliada a baixos níveis escolares, está a profissão do lar, onde muitos indivíduos não conseguem se inserir no mercado de trabalho e remetem a superlotação habitacional, levando a um aumento na 
transmissão do bacilo da tuberculose e, consequentemente, a elevação da incidência de tuberculose (TEIXEIRA e COSTA, 2011).

Além disso, essas vulnerabilidades podem ser de natureza exógena, determinadas pelas características da fonte de infecção, o meio ambiente e a duração da exposição ao bacilo ou de natureza endógena, que depende da resposta do sistema imune do indivíduo (FARGA, CAMINERO, 2011).

Um dos fatores de risco de maior importância é o Vírus da imunodeficiência humana (HIV) nas infecções recentes de TB. O aparecimento da epidemia do HIV/Aids nos países endêmicos para tuberculose tem motivado um aumento significativo de tuberculose pulmonar com baciloscopia negativa e formas extrapulmonares. A tuberculose é a maior causa de morte entre pessoas que vivem com HIV, sendo a taxa de óbito na coinfecção de $20 \%$. Portanto, o controle da TB/HIV exige a implementação de um programa que permita diminuir a prevalência de ambas as doenças e que seja fundamentado em uma rede de atenção integral, rápida e resolutiva (BRASIL, 2011a; FARGA, CAMINERO, 2011).

Além da coinfecção TB/HIV, há outros condicionantes relacionados à TB como infecções recentes, lesões pulmonares fibróticas, tratamento com anti-FNT, insuficiência renal, transplante renal, enfermidades malignas do sistema linfático, diabetes, hemofilia, tratamentos prolongados com corticosteroides e outros imunossupressores, multirresistência aos quimioterápicos usado no tratamento anti-TB, abuso de substâncias viciantes (tabagismo, alcoolismo), extremos de idade, fatores sociais (empobrecimento da população, urbanização sem planejamento), fatores genéticos e toda depressão severa da imunidade celular (FARGA, CAMINERO, 2011).

\subsubsection{Tuberculose, acessibilidade e acolhimento}

A acessibilidade e o acolhimento são peças chaves para a assistência adequada do doente com tuberculose, de modo a promover a cura da doença e diminuir a possibilidade de retratamento ou abandono (BRASIL, 2011a).

Segundo STARFIELD (2002), o acesso às unidades de saúde para o atendimento é imprescindível. Vai desde a viabilidade do tratamento até o acompanhamento do agravo e o desfecho do caso. Não deve ser diferente a assistência para os doentes de tuberculose, ao contrário, o acolhimento deve ser reforçado e o vínculo estimulado, em função de ser uma 
doença de tratamento prolongado, de no mínimo 6 meses (BRASIL, 2011a). A ausência dessa entrada para o paciente remete à falta de atenção à saúde, uma vez que os sujeitos não obtêm o atendimento de sua demanda ou até mesmo adiam esse cuidado (STARFIELD, 2002). No caso da tuberculose, esse fato retarda o início do diagnóstico e do tratamento, além de manter a transmissibilidade da doença.

Por sua vez, entende-se como acesso a distância da unidade de saúde e o local de moradia da pessoa, o tempo e os meios utilizados para o deslocamento, ou seja, trata-se de obstáculos a serem enfrentados pelos doentes até a obtenção do atendimento e tratamento (WANG, 2012). A acessibilidade então é caracterizada não só pela relação entre a localização da oferta e dos usuários, mas também a forma e tipo de deslocamento, condições de vida do indivíduo, poder aquisitivo e educação, excedendo a dimensão geográfica (UNGLERT, 1995). Apesar da distância, muitos usuários buscam atendimento em locais mais afastados de sua residência por considerarem que outros serviços, embora mais distantes, sejam de melhor qualidade, daí a importância do acolhimento adequado nos serviços de saúde (RAMOS e LIMA, 2003) e a criação de vínculo.

Neste sentido, o acolhimento está vinculado também às relações entre os profissionais e serviço de saúde com seus usuários (MERHY et al., 1994). Uma pesquisa aplicada em 17 pacientes de uma Unidade de Saúde do Rio Grande do Sul identificou fatores de qualidade do atendimento, e concluiu que a recepção adequada, o respeito ao usuário, a relação humanizada e o bom desempenho profissional foram os elementos fundamentais no acolhimento (RAMOS; LIMA, 2003). Isso poderia explicar a busca da assistência ao doente de tuberculose no DF por outros serviços e mais distantes de sua residência.

\subsection{PROGRAMA NACIONAL DE CONTROLE DA TUBERCULOSE (PNCT)}

Para ampliar e consolidar o tratamento da TB foi criado, em 2004, o Programa Nacional de Controle da Tuberculose (PNCT), baseado numa estratégia fundamentada na descentralização e horizontalização das ações de vigilância, que utiliza da força da atenção básica para reduzir os indicadores de morbimortalidade da doença (SANTOS, 2007; BRASIL, 2011a).

Essa enfermidade apresenta forte associação com as condições socioeconômicas, ou seja, ligada à pobreza, a má distribuição de renda e a concentração populacional urbana. Esse 
cenário tem impacto negativo nas doenças endêmicas como a tuberculose, devido à dificuldade do acesso aos serviços de saúde, afastando o diagnóstico precoce e tratamento adequado dos suspeitos e doentes de TB (DALCOLMO; ANDRADE; PICON, 2007).

O PNCT é baseado na busca de casos, no diagnóstico precoce e adequado e no tratamento do doente até a sua cura (SANTOS, 2007; BRASIL, 2011a). Ele está integrado ao Sistema Único de Saúde (SUS), que foi criado no contexto do final da década de 1980, onde o país estava imerso em uma complexidade política, sendo difícil consolidar uma política nacional de saúde em um país de dimensões continentais. As dificuldades sofridas na trajetória da descentralização são reflexos desse contexto político, que provocou exclusão social, dificultando o acesso aos serviços de saúde e consequentemente aumento dos custos. Sendo assim, nota-se que é preciso alcançar um equilíbrio entre a descentralização dos serviços de saúde e as especificidades de cada região (VIACAVA et. al., 2004). O SUS deveria ser um sistema de saúde unificado, descentralizado e hierarquizado. Para tanto, precisaria estabelecer uma estratégia de regionalização das ações e serviços de saúde em todo território nacional, atendendo à diversidade regional do país (VIACAVA et. al., 2004).

Com o intuito de melhorar o sistema de saúde foi estabelecido, em 2006, o Pacto pela Saúde, que é um conjunto de reformas institucionais pactuadas pelas três esferas de governo (União, estados e municípios). O Pacto pela Saúde envolve comprometimentos sanitários, o SUS mais como política de Estado ao invés de política de governos. Algumas prioridades foram estabelecidas pelo Pacto pela Saúde, entre elas o controle das doenças emergentes e endemias como a tuberculose, sendo o objetivo atingir pelo menos $85 \%$ de cura de casos novos de TB (BRASIL, 2006; CARVALHO et al., 2012).

No Pacto pela Saúde, essas ferramentas de gestão objetivaram o aprimoramento e crescimento do sistema de saúde, por meio da avaliação. É importante que os gestores de saúde percebam a sua importância e comecem a utilizá-la. Essa ferramenta permite que os envolvidos nos serviços de saúde tenham uma lente de aumento e enxerguem não somente as falhas, mas também as melhorias do sistema de gestão estabelecido. Assim, podem monitorar a capacidade dos serviços em responder às necessidades de saúde, acompanhar os efeitos das intervenções e como produto final, mudar a realidade. Além disso, a avaliação pode ser o elo entre o saber acadêmico e os serviços, entre a pesquisa e a gestão, contribuindo para o aprimoramento dos sistemas e serviços de saúde (MARCOLINO, et al., 2009; CARVALHO et al, 2012). 
O Programa Nacional de Controle da Tuberculose (PNCT) ganhará ainda mais força e seu sucesso dependerá da priorização das ações de controle da TB por parte dos gestores nas três esferas de governo estimulando a busca ativa de sintomáticos respiratórios nas unidades de saúde, na comunidade, nas emergências, em grupos de maior risco, tais como população rural, indígena, locais de privação de liberdade e portadores de HIV/Aids. O controle dos casos de TB deve inovar com a incorporação de novas técnicas e tecnologias. No Brasil foi criado um o Sistema de Informação de Agravos de Notificação (SINAN), uma ferramenta essencial para o planejamento, monitoramento e avaliação no controle da doença (SANTOS, 2007).

O SINAN é o sistema nacional adotado para o registro e processamento de dados de notificação e acompanhamento da TB. A qualidade do sistema de informação está diretamente ligada à qualidade do preenchimento dos dados, sendo crucial o comprometimento dos profissionais de saúde, em especial os da atenção básica, que estão inseridos na rotina da comunidade como os profissionais da Estratégia Saúde da Família (ESF) e do Programa de Agentes Comunitários de Saúde (PACS). Os mesmos devem ser treinados e capacitados para realizar diagnósticos e suspeição dos casos, supervisionar e tratar a ingestão de medicamentos, acompanhar os contatos dos portadores de TB, manter atualizado o sistema de informação, realizar ações de integração, educativas, preventivas e de socialização junto à comunidade (SANTOS, 2007).

A ESF é um programa importante já que os municípios são dotados de particularidades (políticas / estruturais / humanas) que os tornam heterogêneos na dinâmica de enfrentamento da doença. Uma pesquisa realizada por Marcolino et al. (2009), sobre avaliação do acesso às ações de controle da tuberculose no contexto das equipes de saúde da família de Bayeux - PB, mostrou que, no Estado da Paraíba, o PACS vem se consolidando à medida que se organiza a rede de assistência à saúde, associado com a ampliação da cobertura da Estratégia da Saúde da Família.

Para o crescimento da ESF como estratégia para o controle da TB é preciso que haja sustentação político-social para mobilizar os setores políticos a priorizar e assegurar a luta antiTB. O apoio financeiro do Estado pela União, bem como a articulação intersetorial ajudarão na realização das ações e atividades de vigilância sanitária e epidemiológica. Outro papel evidenciado e importante para o combate da TB é a participação da sociedade civil, que deve se sentir acolhida pelas equipes de saúde, assegurando o direito de colocar suas opiniões e apontar as dificuldades sofridas pela comunidade, garantindo o controle social estabelecido 
pelo SUS. A função da ESF é levar a assistência até a comunidade e não esperar que a mesma se disponha a procurar o atendimento (SANTOS, 2007).

Atualmente, as políticas de saúde consideram o controle da TB como responsabilidade dos municípios brasileiros e reconhecem o PCNT como competência da atenção básica para melhoramento do acesso ao diagnóstico e tratamento da doença. Para aumentar a qualidade do programa é preciso investir quanti e qualitativamente nos recursos humanos, componente essencial para prevenção e gerenciamento das ações de doenças crônicas como a TB. Em São Paulo, algumas dificuldades foram levantadas em oito municípios - a falta de qualificação do RH, a visão centralizada e fragmentada da organização do controle da TB no sistema de saúde foram umas das principais barreiras apontadas. Pontos negativos como esses podem gerar a frustação e comprometer o acesso dos enfermos e a interação do profissional com o usuário (MONROE, 2008).

\subsection{USO DO GEOPROCESSAMENTO PELO SETOR SAÚDE}

A coleta de dados sobre a distribuição geográfica de recursos minerais, animais, propriedades, plantas e doenças sempre foi fundamental para as atividades das sociedades organizadas. Atérecentemente, essas atividades eram realizadas de forma artesanal e documentadas em mapas. Com a tecnologia da informática, tornou-se possível armazenar tais informações em ambiente computacional chamado de geoprocessamento (CÂMARA; DAVIS; MONTEIRO, 2001).

O termo "geoprocessamento ou georreferenciamento" associa técnicas matemáticas e computacionais, informação geográfica, dados de saúde/doença, cartografias de forma correlacionadas, com importância fundamental para o setor saúde (CÂMARA, DAVIS, MONTEIRO 2001; GARNELO, BRANDÃO, LEVINO, 2005).

Os dados espaciais podem ser analisados de duas formas: primeira, por meio de dados discretos, onde a representação de um elemento ou objeto é uma tentativa de reproduzi-lo o mais precisamente possível. Qualquer elemento gráfico de um mapa pode ser reproduzido, basicamente, por pontos, linhas, áreas ou polígonos. Segundo, dados contínuos, que consistem no uso de uma malha quadriculada regular sobre a qual se constrói, célula a célula, o elemento que está sendo mostrado. A cada célula concede-se um código referente ao atributo analisado; 
sendo assim, o computador será capaz de identificar a que elemento ou objeto pertente determinada célula (CÂMARA; DAVIS; MONTEIRO, 2001).

As técnicas empregadas para o geoprocessamento, nesta dissertação, baseiam-se no tratamento da análise de dados de superfícies. Os dados são dispostos na forma de amostras pontuais, passando por um processo de interpolação, para efetivamente gerar uma representação na forma de grade regular, o que possibilita a análise e representação de variáveis naturais, socioeconômicas associadas ao fenômeno estudado (CAMARGO; DRUCK; CÂMARA, 2004).

Para gerar superfícies que aproximem o fenômeno estudado de forma realista, é necessário moldar sua variabilidade espacial com as combinações em larga e pequena escala, por meio de modelos determinísticos, que são modelos matemáticos que determinam resultados, exatamente, a partir das condições iniciais e são representados, em geral, por três grandes abordagens: modelos determinísticos de efeitos locais; modelos determinísticos de efeitos globais; e modelos estatísticos de efeitos locais e globais (krigagem) (CAMARGO; DRUCK; CÂMARA, 2004).

Nos modelos determinísticos de efeitos locais os pontos da superfície são estimados a partir da interpolação das amostras mais próximas, utilizando funções como inverso do quadrado da distância. A suposição implícita é que predominam os efeitos puramente locais, não sendo realizada qualquer hipótese estatística sobre a variabilidade espacial. Nos modelos determinísticos de efeitos globais a suposição implícita nesta classe de interpoladores é que, para a caracterização do fenômeno em estudo, predominando a variação em larga escala, tendo a variabilidade local menor peso, sendo denominado de interpoladores por superfícies de tendência. Já nos modelos estatísticos de efeitos locais e globais ou de krigagem, os pontos da superfície são estimados a partir da interpolação das amostras mais próximas, utilizando um estimador estatístico (CAMARGO; DRUCK; CÂMARA, 2004).

Vários estudos propostos por pesquisadores utilizaram o geoprocessamento para compreender a distribuição de uma doença em um determinado espaço físico, como Aparício e Bitencourt (2004), que ao utilizarem a modelagem espacial e identificaram as zonas de risco de contato (homem x vetor da leishmaniose tegumentar americana) e fatores ambientais, utilizando informações de altitude e densidade de vegetação.

Chiesa et al (2002) usaram o mapeamento espacial para identificar áreas com localização de escolas, centros de saúde, hospitais e associaram às condições socioeconômicas e ambientais. A identificação de populações de risco de adoecimento e o modo de transmissão 
da cólera foram realizados por processamentos espaciais de dados, aplicando-se o mapa de Snow (BARCELLOS; BASTOS, 1996).

Ferreira et al., (2005) identificou em Paracatu, Minas Gerais, diferentes níveis da endemia da hanseníase em adolescentes por área geográfica e assinalou que a enfermidade esteve associada a baixas condições socioeconômicas e sanitárias. Dias et al. (2010), ao analisarem a distribuição espacial da hanseníase por meio do Sistema de Informação Geográfica (SIG), descreveram que a endemia se concentrava em áreas periféricas, onde residiam pessoas com baixa condição socioeconômica. Ou seja, a distribuição espacial das enfermidades mapeadas e analisadas pelo SIG contribuiu para a localização dos eventos por população e de risco, além de apresentação da forma gráfica, a partir dos indicadores epidemiológicos (BURROUGH; MCDONNELL, 1998; CUNHA; QUINTANILHA; SILVA, 2003;DIAS et al, 2010).

Um estudo realizado na província de Mazandaran (norte do Irã) usou a análise espacial para identificar aglomerados da incidência da doença tuberculosa e com isso melhorar o programa de saúde local (YAZDANI-CHARATI et al., 2014). Outro estudo proposto por Acosta e Bassanesi (2014) utilizou técnicas de análise geográfica para verificar a distribuição espacial da taxa de incidência da tuberculose pulmonar bacilífera pelos bairros de Porto Alegre, capital brasileira, e com isso, verificaram que a incidência da tuberculose na cidade se mostrou associada a fatores socioeconômicos.

Além de identificar as áreas de maior risco de adoecimento, a ciência da geoinformação permite calcular a distância percorrida pelo paciente até as unidades de tratamento, permitindo verificar a acessibilidade dos mesmos. Uma pesquisa realizada no Nordeste do Brasil calculou as distâncias percorridas pelos pacientes de TB e também identificou fatores associados a acessibilidade para os serviços de saúde. Com isso foi possível estabelecer que acesso dificultado para os serviços de saúde é quando a distância percorrida pelo paciente for maior do que 800 metros. Sendo assim, os sistemas de informação geográfica são cruciais para promover a compreensão do comportamento de uma doença e sua relação com variáveis sociais e o acesso pacientes para realizar o tratamento da enfermidade.

Para Câmara e Davis (2001), o SIG tem custo baixo, pode contribuir na estruturação e análise de riscos socioambientais, fundamentais nos estudos de incidência e prevalência dos agravos à saúde, entre elas a tuberculose (TB) (CARVALHO et al., 2012; APARÍCIO; BITENCOURT, 2004;SKABA, 2004). 
Enfim, o uso dessas ferramentas permite levantar a situação de saúde, revelam as condições de vida e o perfil de adoecimento e morte das populações, evidenciando seus determinantes e condicionantes (causas e consequências), e constitui-se em subsídio fundamental para o processo de planejamento de ações para o enfrentamento contínuo dos problemas identificados.

Os mapas são instrumentos extremamente úteis que auxiliam nesta tarefa. Eles permitem que se represente alguns aspectos concretos do espaço geográfico; em outras palavras, um mapa é antes de tudo uma forma de organização e de transmissão de informações, um meio de comunicação (BRASIL, 2007) de dados, propício para uma intervenção, inclusive para o setor saúde. 


\section{MATERIAIS E MÉTODOS}

\subsection{TIPO DE ESTUDO}

Trata-se de um estudo do tipo transversal, realizado no Distrito Federal (DF), cuja capital é também a capital do Brasil, Brasília. Os estudos transversais se caracterizam pela observação direta e planejada da população ou amostra representativa, em um único momento. Ou seja, o estudo fornece um retrato da população sujeita ao estudo e demonstra, naquele momento, como as variáveis analisadas estão relacionadas (PEREIRA, 2013).

Como método de estudo, os transversais têm suas vantagens e limitações em sua execução. Tem como vantagens a capacidade de investigar uma ampla gama de problemas de saúde pública, com simplicidade e baixo custo, rapidez, objetividade na coleta e análise dos dados. Também, não há necessidade de acompanhar o sujeito do estudo por longos períodos de tempo e a facilidade de se obter amostras representativas na população (MEDRONHO, 2011).

As desvantagens do método é que o estudo dificulta o estabelecimento das relações temporais entre exposição e efeito, dificulta o estabelecimento de relação causal e não é recomendado para doenças com evolução rápida (MEDRONHO, 2011). 


\subsection{LOCAL DE ESTUDO}

O DF está dividido em 31 Regiões Administrativas (RAs), representadas por 15 Regionais de Saúde (Quadro 1) (DISTRITO FEDERAL, 2012).

Quadro 1. Regionais de Saúde e suas respectivas Regiões Administrativas do Distrito Federal.

\begin{tabular}{|l|l|}
\hline \multicolumn{1}{|c|}{ Regional de Saúde (1) } & \multicolumn{1}{|c|}{ Região Administrativa ${ }^{(1)}$} \\
\hline Sul & Brasília (Asa Sul), Lago Sul \\
\hline Núcleo Bandeirante & $\begin{array}{l}\text { Núcleo Bandeirante, Riacho Fundo I, Riacho Fundo II, Park } \\
\text { Way, Candangolândia }\end{array}$ \\
\hline Guará & $\begin{array}{l}\text { Setor de Indústria e Abastecimento (S. I. A), Setor } \\
\text { Complementar de Indústria e Abastecimento (SCIA) } \\
\text { (Estrutural), Guará }\end{array}$ \\
\hline Norte & $\begin{array}{l}\text { Brasília (Asa Norte), Lago Norte, Cruzeiro, Varjão, } \\
\text { Sudoeste/Octogonal }\end{array}$ \\
\hline Ceilândia & Ceilândia \\
\hline Brazlândia & Brazlândia \\
\hline Taguatinga & Taguatinga, Águas Claras, Vicente Pires \\
\hline Samambaia & Samambaia \\
\hline Recanto das Emas & Recanto das Emas \\
\hline Sobradinho & Sobradinho, Sobradinho II \\
\hline Planaltina & Planaltina \\
\hline Paranoá & Paranoá, Jardim Botânico, Itapoã \\
\hline São Sebastião & São Sebastião \\
\hline Gama & Gama \\
\hline Santa Maria & Santa Maria \\
\hline
\end{tabular}

Fonte: ${ }^{(1)}$ Secretaria de Estado de Saúde do Distrito Federal, 2012.

\section{3 ÁREA E POPULAÇÃO DE ESTUDO}

O estudo abrangeu a área do Distrito Federal, que está localizado entre os paralelos de $15^{\circ} 30^{\prime}$ e $16^{\circ} 03^{\prime}$ de latitude sul e os meridianos de $47^{\circ} 25^{\prime}$ e $48^{\circ} 12^{\prime}$ de longitude WGr, na Região Centro-Oeste, ocupando o centro do Brasil e o centro-leste do Estado de Goiás. Sua área é de $5.789,16 \mathrm{~km}^{2}$, equivalendo a $0,06 \%$ da superfície do País, sendo que o número médio de moradores por domicílio urbano era de 3,7 pessoas, de acordo com a Pesquisa Distrital por Amostra de Domicílios (PDAD) realizada em 2004 e 2011 (DISTRITO FEDERAL, 2004; DISTRITO FEDERAL, 2012). O estudo envolveu 3.282 pacientes com diagnóstico de caso novo de TB. 


\subsection{BASE DE DADOS}

Os dados demográficos e socioeconômicos foram obtidos do Instituto Brasileiro de Geografia e Estatística - IBGE (BRASIL, 2016) e da Companhia de Planejamento do Distrito Federal - CODEPLAN (DISTRITO FEDRAL, 2015b). Os casos novos de tuberculose foram obtidos do Sistema Nacional de Agravos de Notificação (SINAN-TB) da Secretaria de Saúde do Distrito Federal, no período de 2003 a 2012. Para os anos em que os dados populacionais não tiveram estimativas oficiais (2004, 2005, 2006, 2007, 2008, 2009, 2010), os dados populacionais foram estimados pelo método de interpolação linear.

\subsection{CRITÉRIOS DE INCLUSÃO}

Foram incluídos somente os casos novos de TB, sendo a totalidade pulmonar bacilíferos ou não, extrapulmonares e pulmonar + extrapulmonar e residentes do Distrito Federal, independentemente do sexo.

\subsection{CLASSIFICAÇÃO DE "CASO", "CURA" "FORMA PULMONAR", "EXTRAPULMONAR", "PULMONAR + EXTRAPULMONAR" DA TUBERCULOSE E MUDANÇA DE DIAGNÓSTICO}

Definiu-se como "caso novo" de TB pessoas não submetidas ao tratamento antiTB ou o fizeram por até 30 dias ou há mais de cinco anos de tratamento.

É considerado caso suspeito todo indivíduo com clínica sugestiva de TB pulmonar, tosse e expectoração por três ou mais semanas, febre, perda de peso e apetite, além de pacientes com imagem radiológica compatível com TB (BRASIL, 2011a).

Foi classificado como "cura" de tuberculose os pacientes com negativação de duas culturas consecutivas, com intervalo mínimo de 30 dias, a partir da administração do número de doses preconizadas, segundo o esquema terapêutico administrado, sem sinais clínicos e radiológicos de doença ativa (BRASIL, 2011a).

A identificação de forma pulmonar da tuberculose bacilífera é por meio de duas baciloscopias diretas positivas ou uma baciloscopia direta positiva e cultura positiva ou uma baciloscopia direta positiva e imagem radiológica sugestiva de tuberculose (BRASIL, 2011a). 
Define-se caso de tuberculose extrapulmonar paciente com evidências clínicas e achados laboratoriais, inclusive histopatológicos, compatíveis com tuberculose extrapulmonar ativa, em que se trata com esquema específico; ou paciente com, pelo menos, uma cultura positiva para Mycobacterium tuberculosis, de material proveniente de uma localização extrapulmonar. O doente de TB poderá apresentar concomitantemente a forma pulmonar e extrapulmonar da tuberculose (pulmonar + extrapulmonar) (BRASIL, 2011a).

É considerado "mudança de diagnóstico" de tuberculose o paciente que, ao longo do seu tratamento, for constatado erro no diagnóstico de tuberculose (BRASIL, 2011a).

\subsection{CRITÉRIOS DE EXCLUSÃO}

Foram excluídos $6,5 \%$ de pessoas sem identificação de endereço, regional de saúde $(0,3 \%)$, não-residentes no $\mathrm{DF}(0,4 \%)$, mudança de diagnóstico $(4,7 \%)$ e a população privada de liberdade $(1,1 \%)$, num total de $427(13 \%)$ pessoas.

\subsection{VARIÁVEIS ANALISADAS}

Consideraram-se as variáveis sociodemográficas, endereço residencial por regional, local de diagnóstico, de tratamento e evolução do tratamento da TB.

$\mathrm{Na}$ avaliação da influência das condições socioeconômicas e da taxa de cura, do coeficiente de incidência (CI) e do coeficiente médio de incidência (CMI) da TB, examinaramse variáveis independentes:

- Escolaridade (percentual de analfabetos por regional de saúde);

- Renda domiciliar (per capita média mensal em salários mínimos - SM);

- Ocupação do lar (percentual de pessoas do lar). Ocupação do lar refere-se a pessoa que exerce somente atividades domésticas, no próprio domicílio, não sendo, portanto, remunerada (DISTRITO FEDERAL, 2012a).

- Fecundidade (número de nascidos vivos por regional de saúde por número de mulheres em idade fértil);

- Envelhecimento (pessoas com 60 anos ou mais);

- Mortalidade (número de óbitos por faixa etária por população);

- Violência (número de óbitos por causas externas por número total de óbitos). 


\subsection{ANÁLISE DOS DADOS}

$\mathrm{Na}$ análise utilizaram-se os endereços dos pacientes com TB por regional de saúde/Centro de Saúde, de residência e o resultado do encerramento de caso. Todos os casos de TB utilizadas no estudo foram georreferenciados no sistema de informação geográfica Google Earth Pro (software gratuito). A partir de então, criaram-se pontos de localização geográficas (latitude e longitude) sendo processados no Sistema de Informação Geográfica (SIG), ArcGIS 10.3, o que permitiu a análise por distribuição espacial, realizada pelo método Inverso da Distância Ponderada (IDW) por regional de saúde.

O IDW teve como função estimar a intensidade dos casos a partir da interpolação das amostras mais próximas, cujo objetivo é produzir superfícies mais suaves, que apresentam maior representatividade para fenômenos naturais e socioeconômicos (CAMARGO; DRUCK; CÂMARA, 2004). Trata-se de modelo determinístico com efeito local, cujos valores utilizam uma combinação linear ponderada de um conjunto de pontos da amostragem. A superfície a ser interpolada deve ser a de uma variável localizadamente dependente. Assim, os dados próximos serão mais influenciados à medida que a potência aumenta, ou seja, os valores interpolados aproximam-se do ponto da amostra mais próxima (WATSON; PHILIP, 1985). O IDW assinala que valores próximos de zero indicam a inexistência de autocorrelação espacial e quanto mais elevado, mais forte a autocorrelação (intensidade), ou seja, maior proximidade dos doentes de TB e a Unidade de Saúde. As variáveis dependentes utilizadas foram as Unidades de Saúde.

Para estimar o risco de adoecimento de tuberculose por regional de saúde foi utilizado o Coeficiente de Incidência (CI), que constitui medida do risco de doença ou agravo, especialmente nos estudos da etiologia de doenças agudas e crônicas. O CI é a razão entre o número de casos novos de uma doença que ocorre em uma coletividade, em um intervalo de tempo determinado, e a população exposta ao risco de adquirir a referida doença no mesmo período, multiplicando-se o resultado por 100 mil. Ele é utilizado para analisar variações geográficas e temporais na distribuição dos casos confirmados de tuberculose e subsidiar o planejamento, a gestão, a avaliação de políticas e ações de saúde para o controle da tuberculose em locais de risco (PEREIRA, 2013). 


$$
\begin{aligned}
& \mathrm{n}^{\mathrm{o}} \text { de casos novos de uma doença, ocorridos em determinada comunidade, }
\end{aligned}
$$

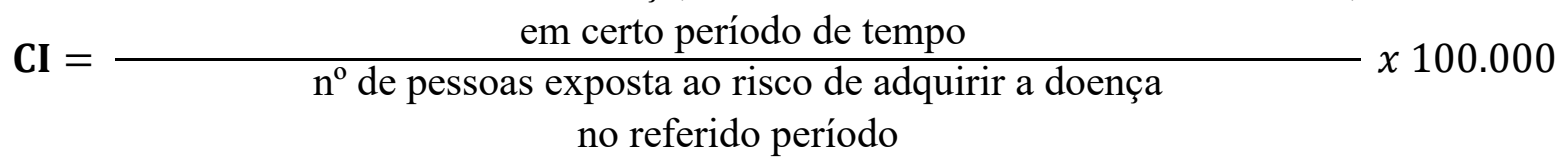

Na tendência da série histórica do CI de TB (2003 a 2012), utilizou-se a técnica de regressão linear simples para avaliação da variação temporal. Os modelos de regressão são modelos matemáticos que relacionam o comportamento de uma variável Y com uma variável X. Esse relacionamento pode ser linear (equação reta ou de plano) ou não linear (equação exponencial, geométrica e outras). O modelo de regressão pode ser simples quando envolve uma relação causal entre duas variáveis, ou multivariado, quando ocorre uma relação causal com mais de duas variáveis (BUSSAB e MORETTIN, 2013). No estudo foi utilizado o modelo de regressão linear simples, pois os coeficientes de incidência apresentaram comportamento linear.

Para avaliar a associação de variáveis sociais e o CI de TB, aplicou-se o coeficiente de correlação de Spearman (BUSSAB; MORETTIN, 2013). Esse coeficiente mede a intensidade da relação entre variáveis ordinais e não é sensível a assimetrias na distribuição dos dados, sendo assim, não exige que eles provenham de duas populações normais. O coeficiente de Spearman varia de entre -1 e 1. Quanto mais próximo estiver desses extremos, maior será a associação entre as variáveis, indicando uma forte relação entre elas. O sinal negativo da correlação significa que as variáveis variam no sentido oposto, ou seja, as categorias mais elevadas de uma variável estão associadas as categorias mais baixas de outra variável (BUSSAB e MORETTIN, 2013).

$\mathrm{Na}$ análise considerou-se o nível de significância de 5\% e o software utilizado foi o SPSS versão 18.0 .

\subsection{ASPECTOS ÉTICOS}

Para realização do referido estudo, o projeto foi previamente submetido e aprovado pelo Comitê de Ética em Pesquisa da Secretaria de Estado de Saúde do Distrito Federal, parecer número 1.037.141, encontra-se no (Anexo I). 


\section{RESULTADOS}

Analisou-se 3.282 casos novos de TB registrados no SINAN do DF em 10 anos de observação. Observou-se na Tabela 1 que o coeficiente médio de incidência (CMI) no DF foi de 13,6 por 100.000 habitantes, com queda anual de $2,2 \%$ e significância estatística $(p=0,002)$.

O coeficiente médio de incidência, nos dez anos de análise, foi maior na regional do Paranoá com 22,5/100.000 habitantes e menor na regional Norte (10,3/100.000 habitantes). A menor incidência de TB observada em todo o período foi observada na regional do Guará com 4,6/100.000 habitantes de CI, em 2010.

Ficou evidente uma redução na incidência de TB no DF com queda significativa na regional de saúde da Asa Norte $(\mathrm{p}=0,042)$, Taguatinga $(\mathrm{p}=0,006)$ e Samambaia $(\mathrm{p}=0,045)$, ou seja, houve uma queda de $0,9 \%, 4,4 \%$ e $1,1 \%$ ao ano, respectivamente. No Núcleo Bandeirante, observou-se uma variação significativa $(\mathrm{p}=0,041)$ com média de aumento anual de incidência de tuberculose de 5,5\%. Não foram observadas diferenças significativas nas incidências de TB nesse estudo, nas regionais do Guará, Brazlândia, Planaltina, São Sebastião e Paranoá.

As regionais de Santa Maria (15,3 casos/100.000 habitantes), Núcleo Bandeirante (14,6 casos/100.000 habitantes), Samambaia (15,7 casos/100.000 habitantes), Sobradinho (13,3 casos/100.000 habitantes), Planaltina (17,1 casos/100.000 habitantes), Recanto das Emas (15,0 casos/100.000 habitantes), Guará (13,8 casos/100.000 habitantes) e Paranoá (22,5 casos/100.000 habitantes) obtiveram os maiores CMI de TB do DF, durante o período analisado, mostrando que estas áreas têm um risco maior de ocorrer a doença tuberculosa (Tabela 1). 
Tabela 1. Coeficiente de incidência da tuberculose por regional de saúde e ano de diagnóstico no Distrito Federal, período de 2003 a 2012.

\begin{tabular}{|c|c|c|c|c|c|c|c|c|c|c|c|c|c|}
\hline \multirow{2}{*}{ Regional de Saúde } & \multicolumn{10}{|c|}{ Coeficiente de Incidência ${ }^{(1)}$} & \multirow{2}{*}{$\mathbf{C M I}^{(2)}$} & \multirow{2}{*}{$\begin{array}{l}\text { Variação } \\
\text { média } \\
\text { anual }(\%)\end{array}$} & \multirow{2}{*}{ p-valor ${ }^{(3)}$} \\
\hline & 2003 & 2004 & 2005 & 2006 & 2007 & 2008 & 2009 & 2010 & 2011 & 2012 & & & \\
\hline Distrito Federal & 16,8 & 16,3 & 14,3 & 13,8 & 15,5 & 12,5 & 11,7 & 11,0 & 11,1 & 13,0 & 13,6 & $-2,2$ & 0,002 \\
\hline Sul & 9,5 & 12,1 & 13,5 & 12,3 & 15,8 & 17,2 & 10,4 & 6,7 & 8,2 & 8,7 & 11,4 & 2,4 & 0,263 \\
\hline Núcleo Bandeirante & 18,7 & 25,2 & 15,7 & 15,3 & 23,6 & 9,8 & 6,2 & 7,3 & 10,0 & 14,2 & 14,6 & 5,5 & 0,041 \\
\hline Guará & 15,5 & 25,9 & 7,0 & 13,1 & 15,6 & 11,1 & 13,5 & 4,6 & 15,4 & 16,0 & 13,8 & 29,8 & 0,456 \\
\hline Norte & 17,9 & 10,6 & 11,1 & 7,8 & 12,1 & 9,7 & 9,6 & 5,5 & 8,7 & 9,4 & 10,3 & $-0,9$ & 0,042 \\
\hline Ceilândia & 15,6 & 15,3 & 17,5 & 13,8 & 17,2 & 15,1 & 13,3 & 18,2 & 11,4 & 17,3 & 15,5 & 4,8 & 0,774 \\
\hline Brazlândia & 10,2 & 14,3 & 14,9 & 11,3 & 17,2 & 5,6 & 3,8 & 9,8 & 16,2 & 7,9 & 11,1 & 16,2 & 0,446 \\
\hline Taguatinga & 17,6 & 13,1 & 12,6 & 9,4 & 9,2 & 8,8 & 9,4 & 6,1 & 8,3 & 9,5 & 10,4 & $-4,4$ & 0,006 \\
\hline Samambaia & 19,2 & 18,9 & 13,2 & 18,3 & 23,9 & 15,7 & 16,6 & 15,8 & 6,4 & 9,3 & 15,7 & $-1,2$ & 0,045 \\
\hline Recanto das Emas & 15,5 & 25,4 & 17,8 & 10,8 & 17,3 & 15,2 & 13,5 & 18,6 & 8,8 & 6,8 & 15,0 & $-0,7$ & 0,051 \\
\hline Sobradinho & 34,1 & 14,3 & 11,7 & 12,4 & 11,7 & 10,4 & 7,0 & 7,9 & 12,4 & 11,4 & 13,3 & $-6,4$ & 0,060 \\
\hline Planaltina & 18,4 & 22,0 & 17,4 & 20,1 & 15,6 & 7,0 & 16,6 & 17,2 & 16,1 & 20,7 & 17,1 & 11,1 & 0,619 \\
\hline Paranoá & 19,0 & 0,0 & 13,4 & 37,6 & 21,8 & 41,9 & 24,8 & 31,6 & 17,9 & 16,5 & 22,5 & 8,1 & 0,462 \\
\hline São Sebastião & 14,4 & 11,5 & 15,1 & 20,9 & 10,8 & 10,2 & 20,0 & 7,9 & 14,1 & 11,3 & 13,6 & 10,0 & 0,550 \\
\hline Gama & 14,9 & 15,2 & 21,1 & 14,7 & 14,8 & 19,2 & 10,5 & 11,7 & 17,3 & 17,5 & 15,7 & 6,3 & 0,784 \\
\hline Santa Maria & 16,8 & 17,8 & 14,9 & 17,7 & 20,5 & 13,1 & 13,0 & 16,2 & 8,4 & 14,8 & 15,3 & 4,6 & 0,106 \\
\hline
\end{tabular}

Notas: ${ }^{\left({ }^{1}\right)} \mathrm{CI}=$ Coeficiente de Incidência anual por 100.000 habitantes.

${ }^{(2)} \mathrm{CMI}=$ Coeficiente Médio de Incidência por 100.000 habitantes, de 2003 a 2012.

${ }^{(3)} \mathrm{p}$-valor = Estimado pelo modelo de regressão linear. 
A Figura 1 apresenta os dados de incidência da tuberculose no Distrito Federal, na série histórica 2003 a 2012. Durante o período analisado, foi constatado que o coeficiente de incidência de tuberculose teve uma diminuição de 2003 a 2006, com posterior aumento em 2007 (15,5/100.000 habitantes) e uma redução subsequente de 2007 até 2011 (11,1/100.000 habitantes), seguida de uma elevação em 2012 (13,0/100.000 habitantes). Na análise da tendência linear, foi possível observar que, em média, a doença mostra uma redução da TB nesse período.

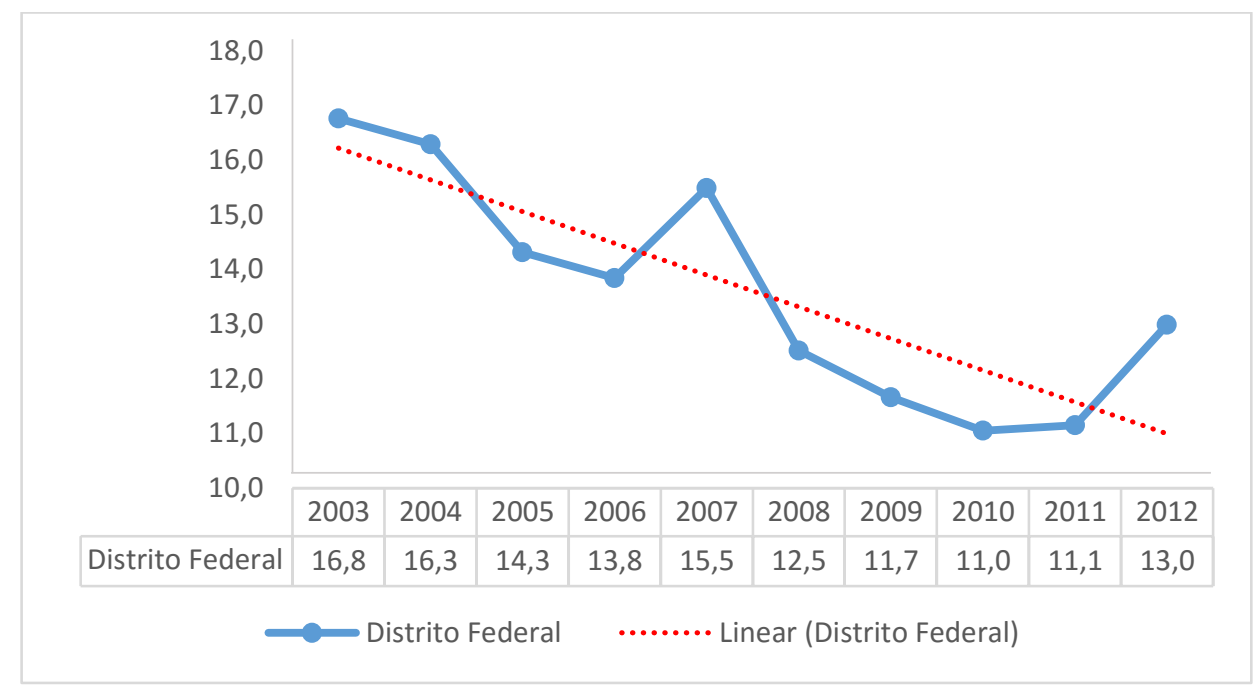

Figura 1. Coeficiente de incidência de tuberculose por 100.000 habitantes da no Distrito Federal, período de 2003 a 2012.

Na Tabela 2, verificou-se que o sexo masculino predominou em todos os anos estudados no Distrito Federal. Notou-se que coeficiente de incidência entre os homens $(p=0,008)$ foi significativamente estatístico. A maior incidência de TB nos homens ocorreu em 2003 (21,1/100.000 habitantes) e o menor coeficiente encontrado foi em 2011 (13,9/100.000 habitantes). $\mathrm{O}$ coeficiente de incidência entre o sexo feminino também apresentou variação significativa ao longo dos dez anos $(\mathrm{p}=0,001)$ e com tendência de queda; o maior CI foi em 2003 (12,8/100.000 habitantes) e menor em 2010 (6,9/100.000 habitantes).

Na análise por regional de saúde do Distrito Federal, em São Sebastião a incidência de tuberculose verificada no período foi mais elevada, nove vezes no sexo masculino $(19,8$ casos/100.000 habitantes) em comparação com o feminino (2,2 casos/100.000 habitantes). As regionais que apresentaram variações significativas ao longo dos dez anos foram a da Sul ( $\mathrm{p}=0,013$ para o sexo feminino), Taguatinga ( $\mathrm{p}=0,018$ para o sexo feminino), Sobradinho 
( $\mathrm{p}=0,033$ para o sexo masculino e $\mathrm{p}=0,001$ no feminino), Planaltina $(\mathrm{p}=0,017$ para o sexo masculino) e Santa Maria ( $\mathrm{p}=0,004$ para o sexo masculino), conforme mostrou a Tabela 2. 
Tabela 2. Coeficiente de incidência dos casos novos de tuberculose, segundo o sexo, por regional de saúde do Distrito Federal, período de 2003 a 2012.

\begin{tabular}{|c|c|c|c|c|c|c|c|c|c|c|c|c|c|c|c|c|c|c|c|c|c|c|}
\hline \multirow{3}{*}{ Regional de Saúde } & \multicolumn{20}{|c|}{ Coeficiente de incidência ${ }^{(1)}$} & \multirow{2}{*}{\multicolumn{2}{|c|}{ p-valor ${ }^{(4)}$}} \\
\hline & \multicolumn{2}{|c|}{2003} & \multicolumn{2}{|c|}{2004} & \multicolumn{2}{|c|}{2005} & \multicolumn{2}{|c|}{2006} & \multicolumn{2}{|c|}{2007} & \multicolumn{2}{|c|}{2008} & \multicolumn{2}{|c|}{2009} & \multicolumn{2}{|c|}{2010} & \multicolumn{2}{|c|}{2011} & \multicolumn{2}{|c|}{2012} & & \\
\hline & $\mathbf{M}^{(2)}$ & $\mathbf{F}^{(3)}$ & $\mathbf{M}$ & $\mathbf{F}$ & $\mathbf{M}$ & $\mathbf{F}$ & $\mathbf{M}$ & $\mathbf{F}$ & $\mathbf{M}$ & $\mathbf{F}$ & $\mathbf{M}$ & $\mathbf{F}$ & $\mathbf{M}$ & $\mathbf{F}$ & $\mathbf{M}$ & $\mathbf{F}$ & $\mathbf{M}$ & $\mathbf{F}$ & $\mathbf{M}$ & $\mathbf{F}$ & $\mathbf{M}$ & $\mathbf{F}$ \\
\hline Distrito Federal & 21,1 & 12,8 & 19,3 & 11,0 & 18,4 & 10,6 & 17,3 & 10,7 & 20,3 & 11,1 & 16,5 & 8,9 & 15,4 & 8,2 & 14,9 & 6,9 & 13,9 & 7,5 & 17,2 & 8,5 & 0,008 & 0,001 \\
\hline Sul & 11,0 & 9,4 & 10,8 & 10,5 & 10,3 & 13,9 & 5,8 & 14,8 & 12,0 & 15,1 & 17,2 & 12,0 & 4,2 & 11,7 & 7,2 & 3,6 & 8,8 & 6,3 & 10,5 & 6,5 & 0,141 & 0,013 \\
\hline Núcleo Bandeirante & 8,4 & 19,3 & 32,7 & 17,0 & 21,6 & 14,5 & 26,8 & 10,6 & 34,3 & 23,5 & 17,2 & 8,0 & 6,7 & 9,4 & 8,2 & 10,6 & 11,3 & 8,8 & 25,2 & 4,3 & 0,638 & 0,091 \\
\hline Guará & 22,9 & 12,0 & 44,9 & 10,3 & 11,6 & 4,2 & 17,8 & 11,1 & 19,0 & 12,6 & 16,7 & 6,0 & 21,8 & 5,9 & 5,4 & 3,5 & 20,4 & 8,3 & 20,3 & 10,8 & 0,283 & 0,715 \\
\hline Norte & 17,0 & 17,3 & 13,6 & 8,9 & 16,0 & 9,4 & 7,8 & 9,2 & 17,5 & 7,4 & 10,0 & 9,2 & 10,6 & 8,3 & 6,7 & 4,3 & 13,7 & 3,0 & 10,5 & 7,7 & 0,864 & 0,074 \\
\hline Ceilândia & 22,6 & 11,5 & 16,6 & 10,8 & 19,1 & 13,8 & 16,1 & 9,2 & 21,5 & 11,0 & 16,9 & 10,9 & 17,1 & 7,0 & 25,6 & 5,9 & 12,5 & 8,9 & 23,9 & 10,0 & 0,273 & 0,269 \\
\hline Brazlândia & 14,4 & 7,0 & 21,1 & 3,5 & 20,2 & 6,6 & 13,2 & 6,5 & 21,3 & 10,5 & 6,8 & 3,3 & 6,6 & 0,0 & 13,9 & 3,4 & 18,2 & 10,5 & 11,5 & 3,6 & 0,266 & 0,439 \\
\hline Taguatinga & 23,0 & 13,8 & 16,1 & 10,7 & 23,9 & 6,1 & 15,1 & 8,0 & 13,8 & 7,9 & 13,1 & 8,1 & 16,7 & 6,8 & 10,4 & 4,3 & 10,4 & 6,7 & 10,5 & 8,8 & 0,481 & 0,018 \\
\hline Samambaia & 29,4 & 10,0 & 23,1 & 8,7 & 15,5 & 8,3 & 16,2 & 16,3 & 26,4 & 21,5 & 20,5 & 10,8 & 19,0 & 13,7 & 16,8 & 12,0 & 9,9 & 2,8 & 11,3 & 7,2 & 0,808 & 0,099 \\
\hline Recanto das Emas & 22,5 & 15,8 & 30,1 & 21,3 & 23,0 & 14,8 & 15,0 & 7,2 & 24,0 & 8,3 & 16,3 & 11,0 & 14,4 & 9,3 & 23,4 & 7,6 & 13,7 & 3,0 & 11,9 & 1,4 & 0,505 & 0,463 \\
\hline Sobradinho & 24,2 & 12,6 & 16,3 & 11,0 & 18,4 & 9,2 & 15,3 & 16,7 & 26,9 & 6,2 & 23,1 & 8,3 & 12,6 & 9,3 & 18,9 & 7,0 & 12,7 & 10,6 & 12,8 & 9,5 & 0,033 & 0,001 \\
\hline Planaltina & 27,3 & 12,5 & 22,9 & 15,9 & 20,7 & 11,7 & 23,9 & 12,6 & 19,9 & 9,6 & 10,7 & 2,3 & 17,4 & 12,3 & 16,1 & 13,2 & 19,3 & 9,7 & 28,2 & 11,7 & 0,017 & 0,513 \\
\hline Paranoá & 24,3 & 6,7 & 0,0 & 0,0 & 9,8 & 9,5 & 44,6 & 9,3 & 13,9 & 3,4 & 18,2 & 14,4 & 13,0 & 6,3 & 14,4 & 9,3 & 20,6 & 13,8 & 22,0 & 10,6 & 0,159 & 0,675 \\
\hline São Sebastião & 31,2 & 3,0 & 16,7 & 5,9 & 10,7 & 22,5 & 31,2 & 13,8 & 24,5 & 3,3 & 17,5 & 9,4 & 37,2 & 15,3 & 13,0 & 5,4 & 21,4 & 4,8 & 19,8 & 2,2 & 0,782 & 0,490 \\
\hline Gama & 13,6 & 15,0 & 13,3 & 10,7 & 24,1 & 11,5 & 16,6 & 7,5 & 14,6 & 13,1 & 30,9 & 5,6 & 18,2 & 1,4 & 15,3 & 5,5 & 16,9 & 15,2 & 27,9 & 7,0 & 0,152 & 0,281 \\
\hline Santa Maria & 17,5 & 16,7 & 17,1 & 12,7 & 20,0 & 7,0 & 23,2 & 8,5 & 25,5 & 15,0 & 14,9 & 10,7 & 18,3 & 7,0 & 17,9 & 12,0 & 14,0 & 3,3 & 12,0 & 17,9 & 0,004 & 0,068 \\
\hline
\end{tabular}


Considerando a faixa etária dos casos de tuberculose estudados no Distrito Federal, verificou-se na Tabela 3 que as maiores incidências de casos foram entre os idosos (60 anos ou mais) nos oito primeiros anos (2003 a 2010), passando a ser maior em adultos (25 a 59) a partir de 2011, também conforme a Figura 2. Entre as regionais observou-se padrões distintos em relação ao CI por faixas etárias, oscilando entre os adultos de 25 a 59 anos e idosos. Em 2003, o maior CI foi observado entre os idosos para quase todas as regionais, exceto para a Sul; as regiões com maior CI foram São Sebastião (182,8 casos/100.000 habitantes), Santa Maria (147,4 casos/100.000 habitantes) e Sobradinho (81,7 casos/100.000 habitantes) enquanto que, em 2012, em geral, os maiores coeficientes são observados entre os adultos de 25 a 59 anos, em quase todas as regionais, exceto nas regionais Sul, Guará, Brazlândia e Gama, onde permanece a maior incidência entre os idosos. 
Tabela 3. Coeficiente de incidência de tuberculose segundo faixa etária por regional de saúde. Distrito Federal, 2003 a 2012.

\begin{tabular}{|c|c|c|c|c|c|c|c|c|c|c|c|c|c|c|c|c|c|}
\hline Ano & Faixa etária & 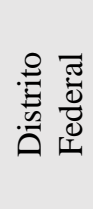 & $\bar{\Xi}$ & 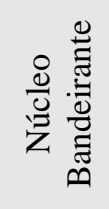 & تّٓ & 䒕 & 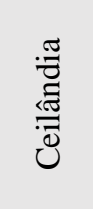 & 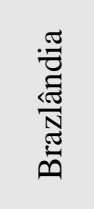 & 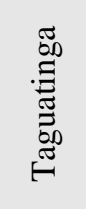 & 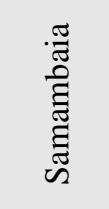 & 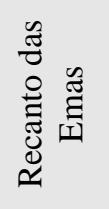 & 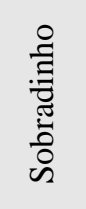 & 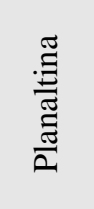 & 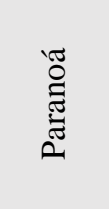 & 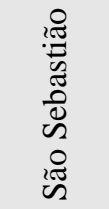 & $\begin{array}{l}\widetilde{E} \\
\text { ש̃ }\end{array}$ & 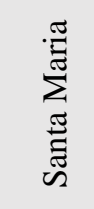 \\
\hline \multirow{4}{*}{2003} & $<15$ anos & 3,7 & - & - & 13,1 & 4,7 & 3,9 & - & 3,1 & 8,5 & 5,2 & - & 3,8 & - & 8,9 & - & - \\
\hline & 15 a 24 anos & 10,2 & 6,9 & 13,6 & 11,3 & 2,4 & 11,1 & 15,8 & 5,0 & 12,4 & 20,2 & 10,2 & 2,9 & 21,0 & 19,3 & 6,7 & 20,7 \\
\hline & 25 a 59 anos & 25,5 & 17,3 & 20,3 & 20,8 & 28,3 & 24,3 & 13,5 & 28,3 & 32,4 & 30,3 & 26,7 & 38,1 & 26,8 & 13,8 & 23,0 & 21,7 \\
\hline & 60 anos ou mais & 41,9 & - & 41,5 & 24,2 & 18,4 & 54,3 & 35,3 & 51,0 & 19,9 & 46,4 & 81,7 & 61,8 & - & 182,8 & 42,6 & 147,4 \\
\hline \multirow{4}{*}{2004} & $<15$ anos & 3,1 & 7,6 & 10,3 & 3,2 & 2,3 & 1,0 & - & 3,1 & 6,6 & 5,1 & 2,4 & 5,5 & - & - & - & - \\
\hline & 15 a 24 anos & 8,2 & 3,4 & 8,9 & 22,1 & 2,3 & 4,4 & - & 9,8 & 12,2 & 9,9 & 10,0 & 11,4 & - & 12,6 & 6,6 & 12,2 \\
\hline & 25 a 59 anos & 21,4 & 9,9 & 26,6 & 30,5 & 14,3 & 21,9 & 26,5 & 18,0 & 17,9 & 52,1 & 21,2 & 32,7 & - & 13,5 & 20,9 & 23,7 \\
\hline & 60 anos ou mais & 52,8 & 34,6 & 162,7 & 94,8 & 36,1 & 58,6 & 34,6 & 31,3 & 116,8 & 45,5 & 26,7 & 45,4 & - & 119,5 & 20,9 & 108,4 \\
\hline \multirow{4}{*}{2005} & $<15$ anos & 3,0 & 7,3 & 3,3 & - & - & 2,7 & 0,0 & 5,9 & 1,6 & 4,9 & - & 1,8 & 4,7 & 12,5 & 4,8 & - \\
\hline & 15 a 24 anos & 8,0 & 9,7 & 17,0 & 10,6 & - & 12,5 & 7,4 & 6,2 & 4,7 & 4,8 & 3,2 & 13,6 & 19,7 & - & 6,3 & 3,9 \\
\hline & 25 a 59 anos & 22,2 & 16,2 & 27,6 & 6,5 & 19,2 & 21,0 & 25,4 & 23,4 & 22,4 & 40,4 & 26,6 & 28,3 & 4,2 & 25,9 & 23,1 & 27,2 \\
\hline & 60 anos ou mais & 36,1 & 6,6 & 19,5 & 34,0 & 34,6 & 71,4 & 33,1 & 12,0 & 37,3 & - & 25,6 & 29,0 & 51,7 & 57,2 & 69,9 & 69,2 \\
\hline \multirow{4}{*}{2006} & $<15$ anos & 1,6 & 3,6 & 3,2 & - & 4,4 & 1,8 & - & - & 3,1 & - & - & 3,5 & - & - & - & 2,5 \\
\hline & 15 a 24 anos & 7,1 & 6,4 & 16,6 & 6,9 & 2,2 & 6,1 & - & 3,1 & 11,4 & 9,3 & 12,5 & 8,0 & 19,3 & 5,9 & 6,2 & 3,8 \\
\hline & 25 a 59 anos & 23,2 & 13,2 & 24,9 & 25,4 & 12,5 & 24,1 & 20,7 & 19,9 & 24,6 & 16,3 & 23,0 & 32,1 & 41,0 & 44,4 & 24,1 & 33,3 \\
\hline & 60 anos ou mais & 30,6 & 19,4 & 57,2 & 11,1 & 11,3 & 5,0 & 32,4 & 23,4 & 91,2 & 128,0 & 62,5 & 56,8 & 202,2 & 112,0 & 0,0 & 33,9 \\
\hline \multirow{4}{*}{2007} & $<15$ anos & 2,0 & - & 3,2 & 5,5 & 2,0 & 2,0 & 5,6 & - & 7,2 & 0,0 & 2,4 & - & - & 4,7 & - & - \\
\hline & 15 a 24 anos & 10,9 & 13,3 & 22,9 & 7,5 & 4,9 & 10,0 & 9,0 & 6,9 & 20,7 & 13,8 & - & 12,8 & 4,0 & 24,6 & - & 34,2 \\
\hline & 25 a 59 anos & 21,9 & 14,0 & 38,8 & 24,7 & 15,0 & 24,5 & 28,7 & 13,6 & 31,6 & 26,1 & 26,9 & 21,5 & 13,5 & 17,7 & 22,7 & 28,2 \\
\hline & 60 anos ou mais & 35,7 & 32,4 & 81,0 & 8,6 & 28,9 & 33,5 & - & 33,9 & 97,4 & 28,8 & 37,8 & 47,3 & 39,0 & - & 36,9 & 29,6 \\
\hline
\end{tabular}


Tabela 3. Coeficiente de incidência de tuberculose segundo faixa etária por regional de saúde. Distrito Federal, 2003 a 2012.

\begin{tabular}{|c|c|c|c|c|c|c|c|c|c|c|c|c|c|c|c|c|c|}
\hline Ano & Faixa etária & 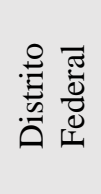 & $\bar{B}$ & 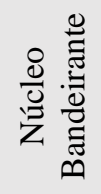 & $\underset{\widetilde{J}}{\tilde{J}}$ & 苛 & 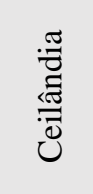 & 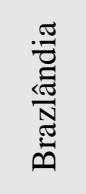 & 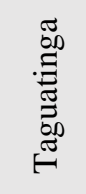 & 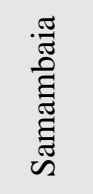 & 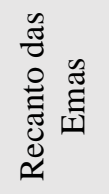 & 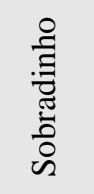 & 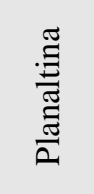 & 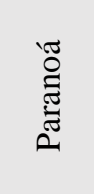 & 宽莺 & $\begin{array}{l}\tilde{\Xi} \\
\text { ల్ }\end{array}$ & 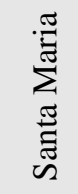 \\
\hline \multirow{4}{*}{2008} & $<15$ anos & 1,9 & - & 3,0 & 2,6 & 7,7 & - & 5,4 & 2,6 & - & - & 2,3 & 0,0 & 2,7 & - & - & 5,6 \\
\hline & 15 a 24 anos & 8,0 & 8,6 & 4,4 & 3,6 & 2,4 & 14,5 & - & 3,3 & 11,4 & 8,9 & 6,9 & 6,2 & 11,5 & - & 12,4 & 14,1 \\
\hline & 25 a 59 anos & 18,8 & 20,5 & 17,5 & 15,5 & 12,1 & 21,0 & 7,7 & 17,1 & 24,8 & 21,4 & 22,9 & 10,2 & 25,4 & 23,4 & 26,1 & 18,4 \\
\hline & 60 anos ou mais & 20,9 & 15,0 & 37,3 & 23,7 & 11,4 & 15,3 & - & 7,8 & 59,6 & 52,8 & 34,8 & 10,8 & 35,8 & 110,0 & 34,0 & - \\
\hline \multirow{4}{*}{2009} & $<15$ anos & 1,6 & - & - & - & 1,9 & 1,0 & - & 1,3 & 1,7 & - & 4,6 & 1,9 & 2,7 & - & 2,8 & 5,6 \\
\hline & 15 a 24 anos & 6,5 & - & - & 7,1 & 2,3 & 2,4 & - & 6,6 & 5,7 & 27,0 & 6,9 & 21,5 & 3,8 & 16,0 & 4,1 & 4,6 \\
\hline & 25 a 59 anos & 16,6 & 10,7 & 11,7 & 17,4 & 13,8 & 19,3 & 7,4 & 15,5 & 27,5 & 15,1 & 16,1 & 16,1 & 12,5 & 41,7 & 13,4 & 16,0 \\
\hline & 60 anos ou mais & 27,3 & 19,6 & 35,1 & 37,5 & 11,1 & 28,5 & - & 26,0 & 55,7 & - & 8,2 & 49,7 & 51,1 & 138,3 & 15,9 & 75,8 \\
\hline \multirow{4}{*}{2010} & $<15$ anos & 1,5 & - & - & - & - & 1,9 & - & - & 1,8 & - & 4,8 & 2,0 & 2,8 & - & - & 8,8 \\
\hline & 15 a 24 anos & 6,3 & - & 4,4 & - & 7,6 & 11,1 & - & - & 13,4 & 16,3 & - & 6,0 & 3,9 & - & 16,9 & 4,6 \\
\hline & 25 a 59 anos & 15,2 & 7,4 & 11,3 & 6,3 & 6,4 & 22,0 & 11,4 & 11,9 & 19,8 & 24,7 & 20,1 & 23,2 & 19,1 & 19,8 & 9,1 & 17,1 \\
\hline & 60 anos ou mais & 20,2 & 8,4 & 37,0 & 12,5 & 6,2 & 26,7 & 42,8 & 10,8 & 37,4 & 18,5 & 20,4 & 32,0 & 26,4 & - & 25,2 & 67,7 \\
\hline \multirow{4}{*}{2011} & $<15$ anos & 2,1 & 4,6 & - & 3,0 & - & - & - & 2,7 & - & - & 5,2 & 8,2 & 5,7 & 4,3 & - & - \\
\hline & 15 a 24 anos & 6,4 & - & - & 22,1 & 8,3 & 3,8 & 10,2 & 5,0 & 5,1 & - & 14,1 & 8,9 & 8,1 & - & 4,3 & 9,0 \\
\hline & 25 a 59 anos & 15,3 & 9,1 & 17,0 & 17,9 & 9,5 & 17,6 & 23,2 & 12,3 & 10,2 & 16,1 & 11,4 & 20,5 & 25,2 & 12,6 & 28,0 & 12,7 \\
\hline & 60 anos ou mais & 14,2 & 10,9 & 15,3 & 5,4 & 10,7 & 15,0 & 19,4 & 6,4 & 7,0 & 14,6 & 23,2 & 13,4 & 32,3 & 121,7 & 15,6 & 12,7 \\
\hline \multirow{4}{*}{2012} & $<15$ anos & 2,4 & - & 3,6 & 3,1 & 5,5 & - & - & 4,1 & 1,9 & 2,9 & - & 10,6 & - & - & - & - \\
\hline & 15 a 24 anos & 8,1 & - & 17,3 & 0,0 & 9,1 & 11,9 & - & 6,6 & - & - & 7,1 & 14,7 & 8,4 & 22,1 & 13,2 & 8,9 \\
\hline & 25 a 59 anos & 18,9 & 9,5 & 17,8 & 20,7 & 12,1 & 28,9 & 11,8 & 12,8 & 17,1 & 12,6 & 16,6 & 26,1 & 29,3 & 13,6 & 22,3 & 24,4 \\
\hline & 60 anos ou mais & 12,6 & 16,1 & 13,0 & 33,0 & 2,3 & 8,9 & 17,7 & 8,8 & 5,7 & - & 15,1 & 23,0 & 9,1 & - & 26,7 & 20,4 \\
\hline
\end{tabular}

Nota: CI = coeficiente de incidência; utilizadas as populações de 2004 e 2013 


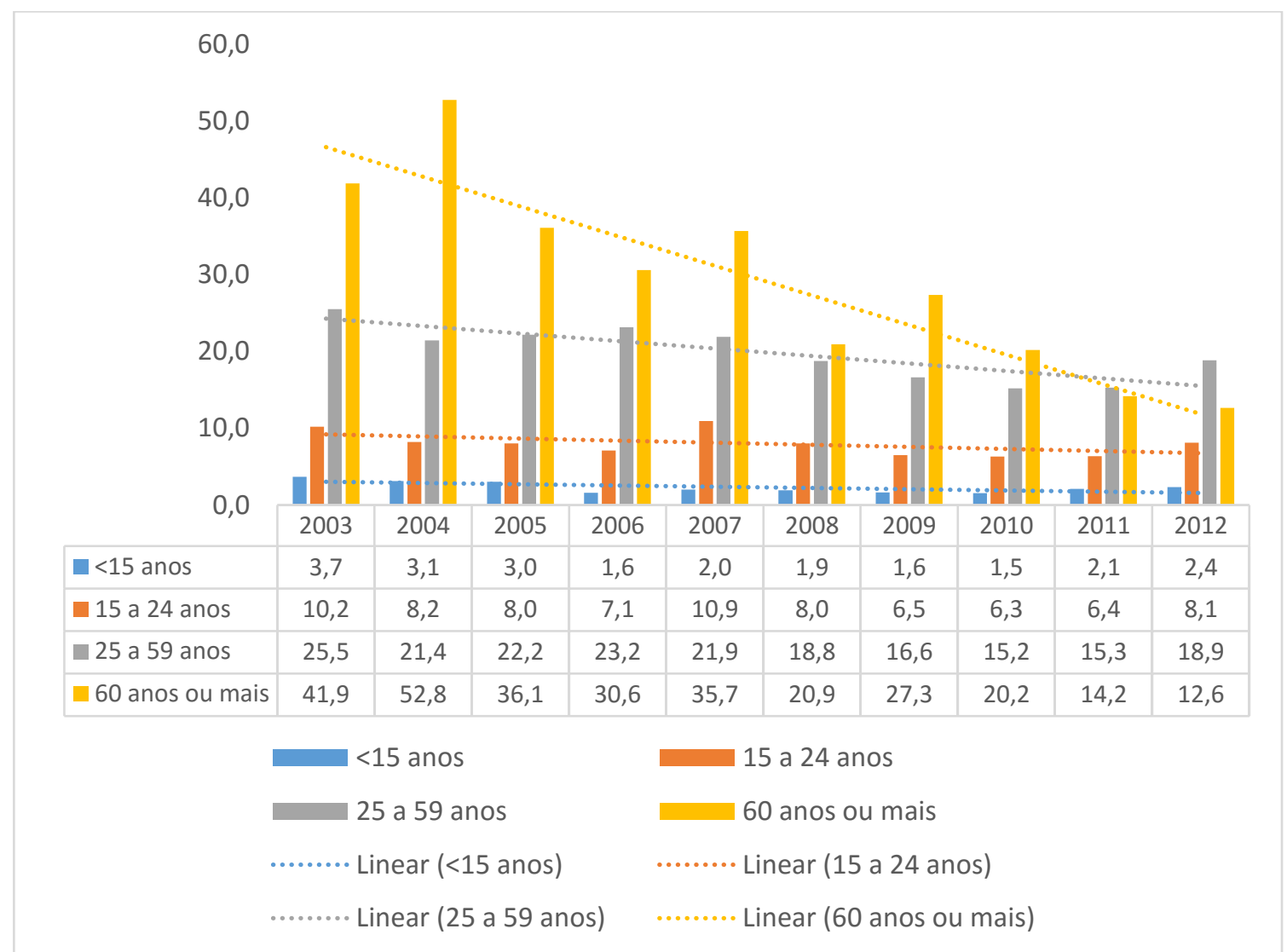

Figura 2. Coeficiente de incidência e linha de tendência de tuberculose segundo faixa etária no Distrito Federal, período de 2003 a 2012.

Na Tabela 4, observa-se que a taxa de cura no DF caiu de 90,2\% (2003) para 81,8\% em 2012. Algumas regionais como a Sul, Brazlândia, Paranoá e São Sebastião chegaram a obter 100\% de cura em 2003, apenas a regional de Sobradinho atingiu essa porcentagem em 2012.

As regionais que obtiveram as melhores taxas médias de cura foram a Sul (92\%), Núcleo Bandeirante (91,0\%), Ceilândia (90,9\%) e Planaltina (90,3\%). O Distrito Federal obteve uma proporção de cura média de $88,6 \%$ no período estudado. 
Tabela 4. Taxa de cura de tuberculose segundo regional e ano de diagnóstico. Distrito Federal, 2003 a 2012.

\begin{tabular}{|c|c|c|c|c|c|c|c|c|c|c|c|}
\hline \multirow{2}{*}{ Regional de Saúde } & \multicolumn{10}{|c|}{ Taxa de cura (\%) } & \multirow{2}{*}{$\begin{array}{c}\text { Taxa } \\
\text { de cura } \\
\text { média }\end{array}$} \\
\hline & 2003 & 2004 & 2005 & 2006 & 2007 & 2008 & 2009 & 2010 & 2011 & 2012 & \\
\hline Distrito Federal & 90,2 & 90,7 & 87,1 & 89,4 & 94,4 & 90,3 & 90,8 & 90,8 & 80,7 & 81,8 & 88,6 \\
\hline Sul & 100,0 & 93,3 & 83,3 & 100,0 & 95,0 & 95,5 & 100,0 & 87,5 & 81,8 & 83,3 & 92,0 \\
\hline Núcleo Bandeirante & 100,0 & 96,0 & 94,7 & 90,0 & 97,0 & 93,3 & 80,0 & 100,0 & 69,2 & 89,5 & 91,0 \\
\hline Guará & 81,0 & 90,9 & 90,0 & 94,7 & 91,3 & 70,6 & 95,2 & 100,0 & 77,3 & 87,5 & 87,9 \\
\hline Norte & 94,3 & 78,3 & 81,5 & 89,5 & 96,7 & 92,0 & 92,0 & 92,9 & 85,0 & 86,4 & 88,8 \\
\hline Ceilândia & 85,5 & 90,2 & 92,2 & 100,0 & 95,2 & 96,4 & 89,8 & 95,4 & 84,8 & 79,7 & 90,9 \\
\hline Brazlândia & 100,0 & 100,0 & 100,0 & 83,3 & 88,9 & 66,7 & 100,0 & 100,0 & 100,0 & 50,0 & 88,9 \\
\hline Taguatinga & 91,5 & 94,3 & 92,5 & 93,8 & 100,0 & 82,4 & 76,3 & 92,0 & 80,6 & 81,1 & 88,4 \\
\hline Samambaia & 91,2 & 100,0 & 81,8 & 77,4 & 95,1 & 100,0 & 100,0 & 89,3 & 69,2 & 70,0 & 87,4 \\
\hline Recanto das Emas & 89,5 & 96,2 & 80,0 & 83,3 & 89,5 & 94,1 & 86,7 & 85,0 & 54,5 & 66,7 & 82,5 \\
\hline Sobradinho & 84,0 & 94,7 & 90,0 & 95,8 & 84,0 & 92,0 & 83,3 & 71,4 & 94,7 & 100,0 & 89,0 \\
\hline Planaltina & 96,8 & 80,6 & 74,1 & 90,3 & 95,8 & 100,0 & 100,0 & 92,3 & 84,6 & 88,9 & 90,3 \\
\hline Paranoá & 66,7 & - & 83,3 & 94,1 & 100,0 & 100,0 & 100,0 & 100,0 & 81,8 & 85,7 & 81,2 \\
\hline São Sebastião & 100,0 & 75,0 & 100,0 & 88,2 & 100,0 & 88,9 & 83,3 & 100,0 & 72,7 & 80,0 & 88,8 \\
\hline Gama & 95,0 & 94,1 & 88,5 & 83,3 & 94,4 & 75,0 & 92,3 & 92,9 & 81,8 & 73,9 & 87,1 \\
\hline Santa Maria & 83,3 & 81,3 & 73,3 & 55,6 & 90,5 & 78,6 & 100,0 & 76,5 & 70,0 & 72,2 & 78,1 \\
\hline
\end{tabular}


Na Tabela 5 nota-se uma associação significativa entre o coeficiente de incidência de TB e todos os indicadores sociais, exceto a taxa de cura que não mostrou associação significativa $(\mathrm{p}=0,128)$. Assim, verificou-se que a medida que aumentou a taxa de fecundidade ( $p<0,001)$, percentual de ocupação do lar $(\mathrm{p}=0,001)$, taxa de violência $(\mathrm{p}<0,001)$, taxa de mortalidade $(p=0,013)$ e proporção de analfabetos $(p=0,001)$, elevou o coeficiente de incidência de tuberculose e, ao contrário, quando aumentou a taxa de envelhecimento $(p>0,001)$, e a renda $(p=0,001)$, diminuiu o coeficiente de TB.

O coeficiente de Spearman apresentou uma associação de forte a moderada $(0,74)$, para o determinante social ocupação do lar. Para os demais indicadores a associação apresentou valores menores que 0,5 , demostrando uma associação mais fraca.

Tabela 5. Correlação entre o coeficiente de incidência, taxa de cura e indicadores de determinantes sociais. Distrito Federal, 2003 a 2012.

\begin{tabular}{|c|c|c|c|c|}
\hline \multirow[t]{2}{*}{ Indicadores } & \multicolumn{2}{|c|}{$\begin{array}{c}\text { Coeficiente de } \\
\text { incidência da TB }\end{array}$} & \multicolumn{2}{|c|}{ Taxa de cura } \\
\hline & Correlação $^{(3)}$ & p-valor & Correlaçãã $^{(3)}$ & p-valor ${ }^{(4)}$ \\
\hline Taxa de cura & 0,125 & 0,128 & - & - \\
\hline Taxa de fecundidade & 0,29 & $<0,001$ & 0,021 & 0,799 \\
\hline Ocupação do lar & 0,74 & 0,001 & - & - \\
\hline Taxa de envelhecimento & $-0,405$ & $<0,001$ & $-0,071$ & 0,387 \\
\hline Violência & 0,391 & $<0,001$ & 0,013 & 0,876 \\
\hline Mortalidade & 0,203 & 0,013 & $-0,079$ & 0,336 \\
\hline Renda $^{(1)}$ & $-0,427$ & 0,001 & $-0,056$ & 0,673 \\
\hline Analfabetos (2) & 0,348 & 0,019 & 0,046 & 0,768 \\
\hline
\end{tabular}

Na Tabela 6, estão apresentados os coeficientes de correlação entre a incidência de tuberculose e os determinantes sociais (cura, mortalidade, violência, envelhecimento e fecundidade) para cada regional do Distrito Federal. Observa-se que as regionais Sul, Núcleo Bandeirante, Guará, Norte, Ceilândia, Samambaia, Recanto das Emas, Planaltina, São Sebastião e Santa Maria não apresentaram associação significativa entre o coeficiente de incidência de tuberculose e todos os indicadores de determinantes sociais. $\mathrm{O}$ indicador de 
mortalidade mostrou-se significativamente associado com o coeficiente de incidência somente com a regional de Sobradinho ( $\mathrm{p}$-valor $=0,043$ ), sendo uma associação positiva com força moderada $(r=0,648)$, ou seja, quanto maior a mortalidade infantil maior é a incidência de tuberculose. O indicador de violência foi estatisticamente significativo nas regionais de Brazlândia (p-valor = 0,011) e Gama (p-valor =0,002), sendo uma associação positiva, isto é, à medida que aumenta o indicador de violência, aumenta também o coeficiente de incidência de tuberculose nestas regionais.

O indicador de envelhecimento apresentou associação significativa com o coeficiente de incidência de tuberculose nas regionais de Taguatinga ( $\mathrm{p}$-valor $=0,030$ ) e Paranoá ( $\mathrm{p}$-valor $=0,047)$; a associação entre estas duas medidas é negativa, ou seja, a medida que aumenta o indicador de envelhecimento, diminui o coeficiente de incidência de tuberculose. A associação entre a fecundidade e o coeficiente de incidência mostrou-se significativamente nas regionais do Paranoá ( $\mathrm{p}$-valor $=0,033)$ e Gama ( $\mathrm{p}$-valor $=0,049)$; nota-se que ambas são associações positivas, indicando que a medida que aumenta a taxa de fecundidade, aumenta o coeficiente de incidência de tuberculose nestas regionais. E, o indicador de cura não mostrou associação significativa com o coeficiente de incidência em nenhuma das regionais de saúde. 
Tabela 6. Correlação entre o coeficiente de incidência com a cura e com indicadores de determinantes sociais por regional de saúde. Distrito Federal, 2003 a 2012

\begin{tabular}{|c|c|c|c|c|c|}
\hline \multirow{2}{*}{ Regional de Saúde } & Cura & Mortalidade & Violência & \multirow{2}{*}{$\begin{array}{l}\text { Envelhecimento } \\
\text { Coef. } \\
\text { Spearmar (p-valor) } \\
\end{array}$} & \multirow{2}{*}{ 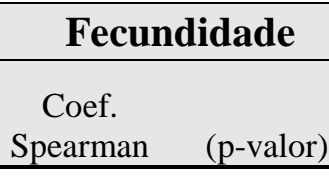 } \\
\hline & $\begin{array}{l}\text { Coef. } \\
\text { Spearman }^{(1)} \quad(p \text {-valor })^{(2)} \\
\end{array}$ & $\begin{array}{l}\text { Coef. } \\
\text { Spearman } \quad \text { (p-valor) }\end{array}$ & $\begin{array}{c}\text { Coef. } \\
\text { Spearman } \\
\end{array}$ & & \\
\hline Sul & $0,182(0,614)$ & $0,091(0,803)$ & $-0,309(0,385)$ & $-0,620(0,056)$ & $0,038(0,917)$ \\
\hline Núcleo Bandeirante & $0,357(0,311)$ & $0,576(0,082)$ & $0,188(0,603)$ & $-0,553(0,097)$ & $0,127(0,727)$ \\
\hline Guará & $0,239(0,506)$ & $-0,455(0,187)$ & $-0,455(0,187)$ & $-0,255(0,476)$ & $0,380(0,279)$ \\
\hline Norte & $0,091(0,803)$ & $0,115(0,751)$ & $-0,006(0,987)$ & $-0,091(0,802)$ & $0,165(0,649)$ \\
\hline Ceilândia & $-0,479(0,162)$ & $0,055(0,881)$ & $-0,358(0,310)$ & $0,055(0,881)$ & $0,272(0,446)$ \\
\hline Brazlândia & $-0,212(0,556)$ & $0,042(0,907)$ & $0,758(0,011)$ & $-0,030(0,934)$ & $0,038(0,917)$ \\
\hline Taguatinga & $0,444(0,199)$ & $0,273(0,446)$ & $0,442(0,200)$ & $-0,681(0,030)$ & $0,539(0,108)$ \\
\hline Samambaia & $0,670(0,048)$ & $-0,236(0,511)$ & $0,394(0,260)$ & $-0,049(0,894)$ & $-0,348(0,324)$ \\
\hline Recanto das Emas & $-0,535(0,111)$ & $0,418(0,229)$ & $-0,370(0,293)$ & $-0,310(0,383)$ & $0,596(0,069)$ \\
\hline Sobradinho & $0,596(0,069)$ & $0,648(0,043)$ & $-0,418(0,229)$ & $-0,371(0,291)$ & $0,336(0,343)$ \\
\hline Planaltina & $0,571(0,085)$ & $-0,006(0,987)$ & $0,576(0,082)$ & $-0,559(0,093)$ & $0,526(0,118)$ \\
\hline Paranoá & $0,200(0,580)$ & $0,273(0,446)$ & $-0,564(0,090)$ & $-0,638(0,047)$ & $0,672(0,033)$ \\
\hline São Sebastião & $-0,188(0,604)$ & $0,297(0,405)$ & $-0,248(0,489)$ & $-0,486(0,154)$ & $-0,564(0,090)$ \\
\hline Gama & $0,399(0,254)$ & $-0,573(0,083)$ & $0,854(0,002)$ & $-0,615(0,059)$ & $0,634(0,049)$ \\
\hline Santa Maria & $0,207(0,567)$ & $0,511(0,132)$ & $-0,012(0,973)$ & $-0,549(0,100)$ & $-0,448(0,194)$ \\
\hline
\end{tabular}


A distância percorrida em metros pelo paciente até a unidade de tratamento de tuberculose variou consideravelmente. A menor distância foi 100 metros $(p=0,092)$ e a maior, 10497 metros $(\mathrm{p}=0,741)$ (Tabela 7). Ao longo dos dez anos, a média percorrida no Distrito Federal foi de 1503 metros.

A técnica de regressão linear não mostrou associação significativa entre a distância percorrida pelo doente e a unidade de tratamento, ou seja, a medida que aumenta a taxa de cura também aumenta a distância percorrida, conforme mostra a Tabela 7. Porém, dois anos mostraram associação significativa, em $2004(\mathrm{p}=0,024)$ e em $2010(\mathrm{p}=0,003)$, que coincide com os dois maiores percentuais de cura para o período estudo, 90,7\% e 90,8\% (tabela 7).

Tabela 7. Correlação entre a distância média percorrida pelo paciente até a unidade de tratamento da tuberculose e o percentual de cura. Distrito Federal, 2003 a 2012.

\begin{tabular}{ccccccc}
\hline $\begin{array}{c}\text { Ano de } \\
\text { diagnóstico }\end{array}$ & $\begin{array}{c}\text { Coeficiente de } \\
\text { Correlação( }^{(\mathbf{1})}\end{array}$ & p-valor & \multicolumn{3}{c}{ Distância em metros } & Taxa de \\
& Mínima & Máxima & Média & cura (\%) \\
\hline 2003 & 0,45 & 0,092 & 100 & 8848 & 2146 & 90,2 \\
2004 & 0,598 & $\mathbf{0 , 0 2 4}$ & 112 & 5884 & 1492 & $\mathbf{9 0 , 7}$ \\
2005 & $-0,118$ & 0,675 & 117 & 5006 & 1265 & 87,1 \\
2006 & 0,434 & 0,106 & 104 & 4852 & 1493 & 89,4 \\
2007 & 0,093 & 0,741 & 133 & 10497 & 1952 & 94,4 \\
2008 & 0,183 & 0,514 & 109 & 4858 & 1505 & 90,3 \\
2009 & 0,076 & 0,789 & 106 & 4847 & 1360 & 90,8 \\
2010 & $-0,706$ & $\mathbf{0 , 0 0 3}$ & 104 & 3927 & 1268 & $\mathbf{9 0 , 8}$ \\
2011 & $-0,083$ & 0,77 & 106 & 3795 & 1278 & 80,7 \\
2012 & 0,054 & 0,85 & 117 & 3618 & 1271 & 81,8 \\
\hline Total & 0,177 & 0,031 & 111 & 5613 & 1503 & 88,6 \\
\hline Notas: ${ }^{(1)}$ Coeficiente de correlação de Spearman \\
${ }^{(2)}$ p-valor = Estimado pelo modelo de regressão linear
\end{tabular}

Verificou-se na Tabela 8 que as menores distâncias percorridas foram na Asa Norte (100 metros), Asa Sul (104 metros), Recanto das Emas (104 metros), Santa Maria (106 metros) e São Sebastião (106 metros). Neste contexto, a maior distância observada foi na Regional de Ceilândia (10497 metros), seguida do Núcleo Bandeirante (5884 metros), Sul (5006 metros) e Brazlândia. 
Tabela 8 - Distância mínima e máxima percorrida pelo paciente até e a unidade de tratamento da tuberculose, por regional de saúde do Distrito Federal, período de 2003 a 2012.

\begin{tabular}{|c|c|c|c|c|c|c|c|c|c|c|c|c|c|c|c|c|c|c|c|c|}
\hline \multirow{2}{*}{ Ano de diagnóstico } & \multicolumn{2}{|c|}{2003} & \multicolumn{2}{|c|}{2004} & \multicolumn{2}{|c|}{2005} & \multicolumn{2}{|c|}{2006} & \multicolumn{2}{|c|}{2007} & \multicolumn{2}{|c|}{2008} & \multicolumn{2}{|c|}{2009} & \multicolumn{2}{|c|}{2010} & \multicolumn{2}{|c|}{2011} & \multicolumn{2}{|c|}{2012} \\
\hline & Mín ${ }^{(1)}$ & $\operatorname{Max}^{(2)}$ & Mín & Max & Mín & Max & Mín & Max & Mín & Max & Mín & Max & Mín & Max & Mín & Max & Mín & $\operatorname{Max}$ & Mín & Max \\
\hline Distrito Federal & 352 & 3940 & 306 & 2678 & 308 & 2222 & 283 & 2704 & 281 & 3623 & 362 & 2648 & 321 & 2400 & 303 & 2234 & 321 & 2236 & 286 & 2256 \\
\hline Norte & 100 & 3885 & 257 & 1288 & 132 & 1970 & 278 & 1363 & 428 & 1731 & 304 & 2132 & 163 & 2314 & 450 & 2283 & 160 & 2141 & 118 & 2073 \\
\hline Sul & 1300 & 8354 & 599 & 5742 & 136 & 5006 & 104 & 4852 & 312 & 4857 & 245 & 4858 & 248 & 4847 & 214 & 3262 & 238 & 3131 & 532 & 3618 \\
\hline Brazlândia & 1000 & 8848 & 187 & 2573 & 1049 & 1790 & 351 & 1943 & 811 & 2447 & 1804 & 2642 & 449 & 1479 & 150 & 1465 & 895 & 1803 & 719 & 1820 \\
\hline Ceilândia & 230 & 3174 & 131 & 1774 & 179 & 3240 & 232 & 3117 & 178 & 10497 & 165 & 1723 & 434 & 3096 & 181 & 1648 & 145 & 1545 & 117 & 2414 \\
\hline Gama & 106 & 2272 & 361 & 1777 & 265 & 1932 & 232 & 1869 & 183 & 1677 & 264 & 1222 & 243 & 949 & 439 & 2310 & 294 & 1266 & 264 & 1277 \\
\hline Guará & 183 & 2956 & 239 & 3612 & 141 & 2830 & 298 & 2808 & 250 & 2801 & 443 & 1654 & 161 & 1759 & 388 & 1966 & 110 & 1130 & 120 & 1075 \\
\hline Núcleo Bandeirante & 140 & 5938 & 261 & 5884 & 158 & 2144 & 214 & 3193 & 183 & 5177 & 204 & 4086 & 187 & 1360 & 439 & 1823 & 205 & 2776 & 225 & 2960 \\
\hline Paranoá & 273 & 1842 & 152 & 900 & 1233 & 1233 & 122 & 1909 & 211 & 1227 & 252 & 2489 & 1208 & 2495 & 145 & 1242 & 640 & 1275 & 332 & 1361 \\
\hline Planaltina & 218 & 2243 & 381 & 1805 & 217 & 3427 & 374 & 2276 & 153 & 5601 & 212 & 2977 & 216 & 3074 & 104 & 3927 & 208 & 2526 & 165 & 2233 \\
\hline Recanto das Emas & 301 & 2991 & 391 & 2655 & 270 & 2542 & 535 & 2486 & 139 & 3711 & 338 & 2153 & 289 & 1325 & 294 & 2438 & 671 & 2213 & 413 & 2509 \\
\hline Samambaia & 140 & 1928 & 294 & 2680 & 160 & 1676 & 232 & 2562 & 220 & 2457 & 302 & 2461 & 314 & 2384 & 248 & 2365 & 273 & 2462 & 337 & 2477 \\
\hline Santa Maria & 535 & 5365 & 187 & 1771 & 126 & 1743 & 498 & 2330 & 133 & 1790 & 173 & 1841 & 281 & 1431 & 183 & 2187 & 106 & 1602 & 135 & 1662 \\
\hline São Sebastião & 490 & 2466 & 731 & 1194 & 117 & 534 & 352 & 3110 & 664 & 2859 & 492 & 1891 & 106 & 1833 & 691 & 884 & 332 & 2164 & 436 & 2341 \\
\hline Sobradinho & 107 & 2079 & 310 & 2441 & 165 & 1456 & 233 & 2847 & 187 & 3592 & 109 & 3998 & 394 & 3767 & 231 & 2699 & 263 & 3708 & 182 & 2844 \\
\hline Taguatinga & 152 & 4755 & 112 & 4067 & 272 & 1812 & 188 & 3898 & 161 & 3927 & 126 & 3595 & 114 & 3887 & 383 & 3004 & 272 & 3795 & 192 & 3181 \\
\hline
\end{tabular}


A Figura 3 mostra o mapa do DF em 2003, suas regionais de saúde e a intensidade dos casos novos de tuberculose, estimados pelo Inverso da Distância Ponderada (IDW). As localidades que apresentaram maior proximidade (intensidade) entre os pacientes e as unidades de tratamento dos casos de TB foram Santa Maria (7,5 a 9,4), Núcleo Bandeirante (7,5 a 13,9), Samambaia (6,5 a 9,4), Sobradinho (7,5 a 9,4), Planaltina (7,5 a 13,9), Recanto das Emas $(6,5$ a 13,9$)$ e Guará de $(6,5$ a 7,4$)$.

Na comparação da TB entre 2003 e 2012 (Figuras 3 e 4), duas regionais mostraram maior proximidade (intensidade) dos doentes de TB em 2012, sendo uma delas Paranoá (até 6,4), em 2003, até 13,9 em 2012; bem como, São Sebastião 6,4 casos próximos no início da observação (2003) e 13,9 em 2012. A distribuição espacial da TB foi semelhante nas demais regionais de saúde nos anos de 2003 e 2012. 


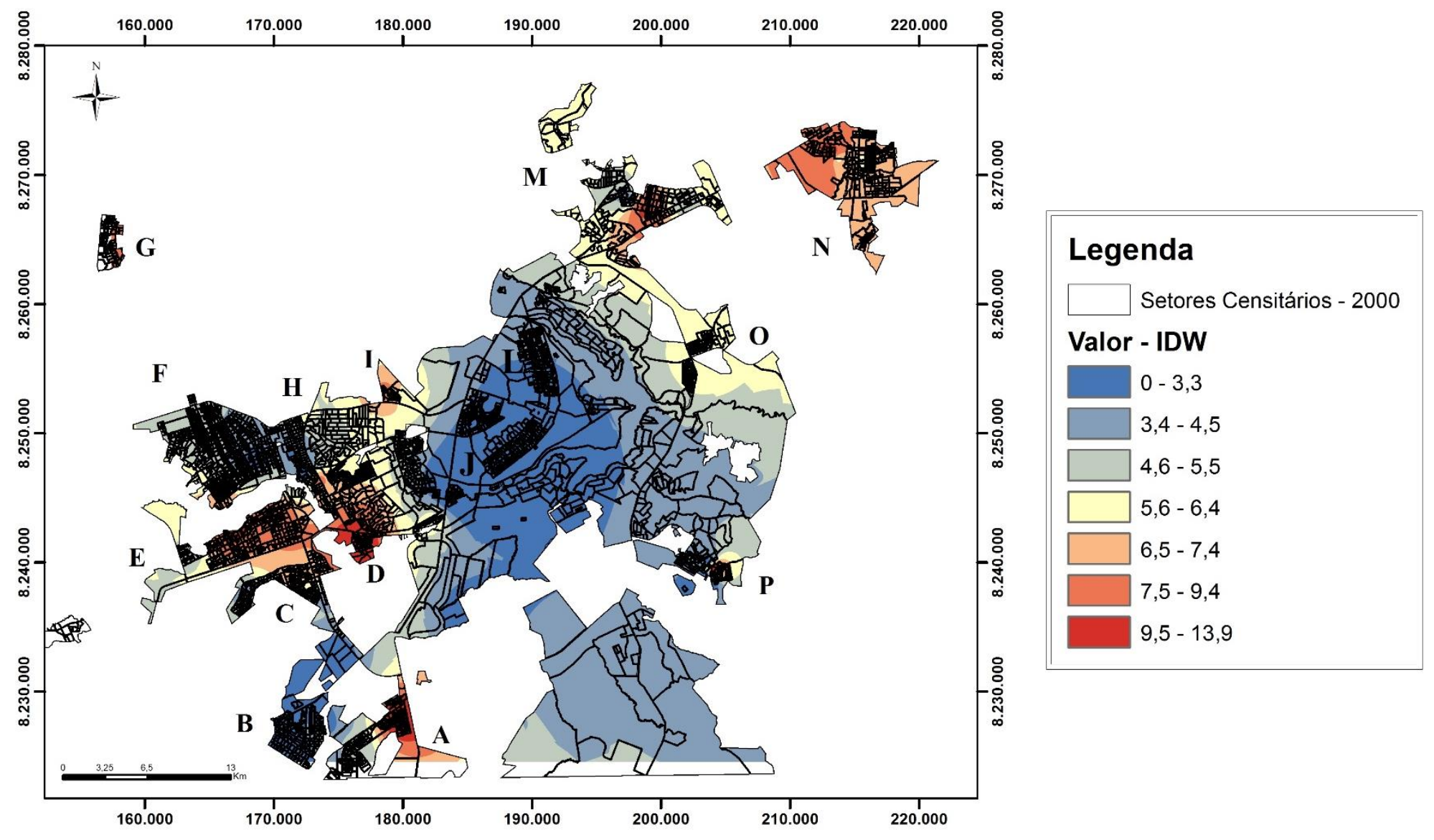

$\mathrm{A}=$ Santa Maria; $\mathrm{B}=$ Gama; $\mathrm{C}=$ Recanto das Emas; $\mathrm{D}=$ Núcleo Bandeirante; $\mathrm{E}=$ Samambaia; $\mathrm{F}=$ Ceilândia; $\mathrm{G}=$ Brazlândia; H=Taguatinga; $\mathrm{I}=$ Guará; J=Sul; L=Norte; M=Sobradinho; N=Planaltina; $\mathrm{O}=$ Paranoá; $\mathrm{P}=$ São Sebastião

Figura 3: Mapa do IDW dos casos de tuberculose por Regional de Saúde do Distrito Federal - 2003. 


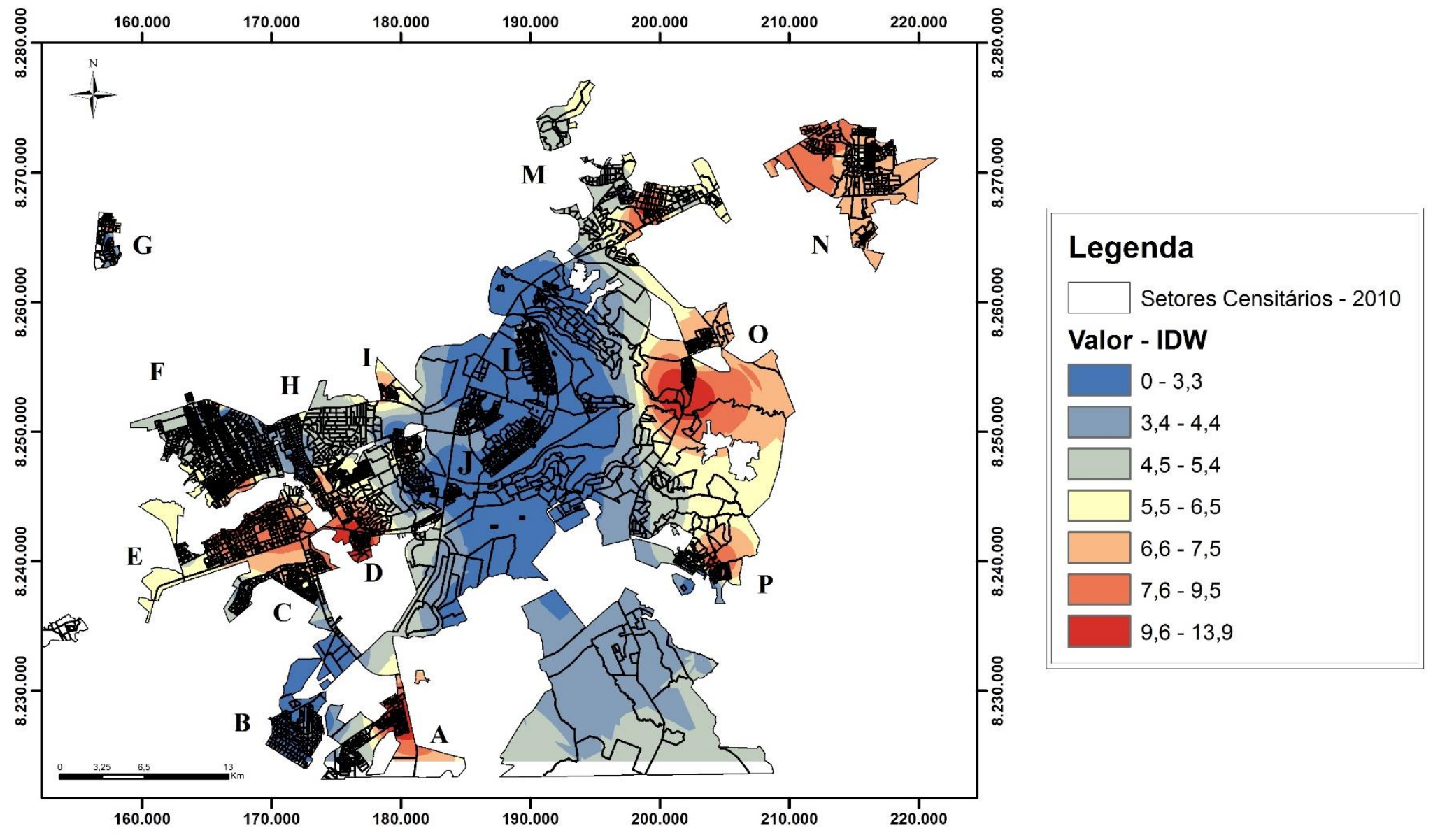

A=Santa Maria; B=Gama; C=Recanto das Emas; D=Núcleo Bandeirante; E=Samambaia; F=Ceilândia; G=Brazlândia; H=Taguatinga; I=Guará; J=Sul; $\mathrm{L}=$ Norte; $\mathrm{M}=$ Sobradinho; $\mathrm{N}=$ Planaltina; $\mathrm{O}=$ Paranoá; $\mathrm{P}=$ São Sebastião

Figura 4: Mapa do IDW dos casos de tuberculose por regional de saúde do DF - 2012. 


\section{DISCUSSÃO}

O Distrito Federal apresentou menos de um terço da incidência de TB em comparação com o Brasil em 2014 (BRASIL, 2015), ou seja, foi 36,1\% menor e isso representou um coeficiente médio de incidência de TB, abaixo de $63 \%$ no período nessa comparação com o país. A incidência da tuberculose no DF se assemelha a de países como Hungria, Espanha e Japão (SANDGREN et al., 2012; WHO, 2015). No entanto, apesar do DF apresentar baixa incidência de TB, não existiu uma distribuição uniforme da carga por regional ao longo do tempo, ao contrário, ela se concentrou em algumas áreas, elevou-se em outra e houve migração TB de umas regiões para outras no tempo, além de redução da cura no período, agregado a um crescimento desordenado na área urbana de 2003 a 2012.

Considerando a análise dos dados de incidência de tuberculose por regional de saúde do DF, a de maior carga da TB mostrou quase metade da média nacional como no Paranoá (22,5 casos/100.000 habitantes) associado a limitações sociais (BRASIL, 2016). O risco de adoecer de TB na regional Paranoá foi duas vezes maior do que a regional Norte. Cabe esclarecer que a regional de saúde do Paranoá conta com uma Unidade de Saúde para a totalidade da população (42.427 habitantes) de seu território, e que provavelmente a acessibilidade se encontra dificultada, fazendo com que o suspeito de tuberculose tenha que ir a busca de serviços assistenciais distante de sua residência (DISTRITO FEDERAL, 2012b). Outra questão, que deve ser abordada é o custo social para o usuário, ele terá que arcar com os valores dos passes de ônibus, com a perda de tempo, e as demais dificuldades do deslocamento, o que de certa forma pode afastar a possibilidade de acesso ao diagnóstico precoce.

Os homens foram os mais acometidos pela TB no Distrito Federal. Nessa casuística, em relação ao sexo, o risco de adoecer de tuberculose foi maior no sexo masculino do que o feminino, embora a distribuição populacional por sexo no Distrito Federal mostrou que 52,5\% é constituída por mulheres (DISTRITO FEDERAL, 2012a). A tuberculose está mais presente em homens, provavelmente, pela maior exposição ao bacilo da TB, associado a fatores ou situações de risco, como o uso de álcool, fumo (NARASIMHAN, 2013), e menor acesso dos homens aos serviços de saúde (BRASIL, 2008), contribuindo para o retardar o diagnóstico precoce da TB.

Dados da Organização Mundial de Saúde mostraram que o alcoolismo representa um problema de Saúde Pública, provocando 7,6\% de mortes nos homens e 4\%, mulheres (WHO, 
2014). Homens e mulheres consomem bebidas alcóolicas em frequências diferentes, eles iniciam precocemente o consumo de álcool, tendem a ingerir maior quantitativo, o que pode levar a ocorrência de mais danos à saúde do que nas mulheres (BRASIL, 2008). Uma pesquisa de caso-controle no Ceará verificou que dentre cinco fatores de risco analisados no adoecimento por TB, o alcoolismo e o tabagismo estavam associados ao desenvolvimento da TBMR adquirida (BARROSO, et al., 2003), mostrando a associação da tuberculose x álcool x TBMR.

Considerando outra questão relacionada a vulnerabilidade das pessoas que adoecem por TB, é o uso de tabaco, muito comum na população de baixa renda (SINGH et al., 2013). Um estudo proposto por Davies (2005) mostrou que os homens assumiram o hábito de fumar com a $1^{\text {a }}$ Guerra Mundial. Pesquisa em Osaka, Japão, apontou que nos pacientes bacilíferos a prevalência de fumantes com tuberculose foi significativamente maior e apresentaram mais lesões cavitárias no pulmão (MATSUMOTO, et al., 2012). Na cidade de Pequim, China, um estudo de caso-controle, analisando a relação entre o fumo e o risco de mortalidade por TB estimou que o tabagismo esteve presente em 22,5\% dos homens e 6,6\% de mulheres, sendo um fator que contribuiu para a maioria das mortes em homens (BONACCI et al., 2013), ou seja, os tabagistas morrem mais, a maioria é homem, apresentam lesões maiores e particularmente, quanto maior o consumo de cigarro, mais afetados pela TB. Enfim, existem evidências da associação entre tuberculose $\mathrm{x}$ tabagismo e o risco de infecção de TB, e provavelmente é o que se observa no DF.

Adicionalmente, estudos comparativos entre homens e mulheres têm assinalado que homens são mais vulneráveis às doenças, especialmente em relação às enfermidades graves e crônicas e morrem mais prematuramente do que as mulheres (COURTENAY, 2000; NARDI et al, 2007). Isso pode estar relacionado ao fato dos homens não buscarem, como as mulheres, o atendimento à saúde (FIGUEIREDO, 2005), principalmente quando o tratamento do agravo for de longa duração como no caso da tuberculose (BRASIL, 2008). Tratamentos longos exigem, por parte do doente, uma grande dedicação e esforço para o seguimento da enfermidade e, muitas vezes, significa mudar seus hábitos de vida, o que pode dificultar no sucesso do tratamento de doenças crônicas (BRASIL, 2008). Outro aspecto importante da não-adesão por parte dos homens, às medidas de atenção integral, decorre das variáveis culturais. Isso significa uma fragilidade masculina que não reconhece os aspectos de adoecimento associado às condições biológicas, rejeitando a possibilidade de adoecer e, consequentemente, não acessam com frequência os serviços de saúde (GOMES, 2003; DE KEIJZER, 2003). 
Uma questão levantada pelos homens pela não procura dos serviços de saúde está ligada à condição de provedor da casa. Eles alegam que os horários dos serviços coincidem com a sua jornada de trabalho e também reclamam da demora do atendimento por parte dos serviços, podendo levar a uma perda do dia de trabalho (BRASIL, 2008). Enfim, os homens no Distrito Federal são os que mais adoeceram por tuberculose e, de acordo com a literatura, este fato está relacionado com álcool e tabaco.

Nesse estudo, a faixa etária mais acometida pela tuberculose nos anos de 2003 a 2010 foram os idosos. Atribui-se ao envelhecimento a diminuição da imunidade celular, onde o corpo sofre várias modificações ao longo dos anos em função da idade, e este aspecto vai favorecer a uma maior suscestibilidade às agressões internas e externas, reduzindo a capacidade defensiva do organismo e a resistência do sistema respiratório, e assim promover o aparecimento de várias doenças, dentre elas a tuberculose (SCHEREINER, 1993, CHAIMOWICZ. 2001; RAJAGOPALAN, 2016). Daí, a observação de uma maior prevalência e pior prognóstico da tuberculose nas pessoas idosas (ROWIŃSKA-ZAKRZEWSKA et al., 2016).

Outro aspecto importante que contribui para um maior adoecimento de tuberculose nessa faixa etária é a associação dessa enfermidade com outras patologias crônicas como a diabetes, doenças cardiovasculares e pulmonares, que são comuns entre os maiores de 60 anos de idade (MACIEL et al, 2010). Em uma revisão sistemática realizada por Uyemura, Castle e Makinodan (2002) e Storla et al., (2008) mostrou que ser idoso é um fator de risco para a doença tuberculosa, especialmente pelo atraso no diagnóstico e no seguimento do tratamento. $\mathrm{Na}$ Ethiopia, um estudo foi desenvolvido por Yimer, Bjune e Alene (2005), sendo que foi observado que pessoas de mais idade são mais dependentes de outras pessoas, seja pela dificuldade de se dirigirem ao serviço de saúde ou devido à dependência na identificação do caso de TB pelo cuidador, o que dificulta o diagnóstico e o tratamento dessas pessoas, e pode levar a um aumento do risco de adoecimento entre os maiores de 60 anos.

Cabe assinalar, que desde 1999, as taxas de notificação de TB no Japão têm sido consistentemente maior entre os pacientes com idades entre 85 anos ou mais velhos do que entre aqueles com idade entre 65 a 84 anos. A proporção de doentes bacteriologicamente positivos de tuberculose na população geral de pacientes com tuberculose pulmonar foi maior entre aqueles com 65 anos ou mais do que entre aqueles com idade entre 15 a 64 anos. Dos doentes com TB e idade de 65 anos ou mais, notificadas em 2013, 31,4\% morreram dentro de um ano após o início do tratamento da TB; destes pacientes, 18,8\% morreu no prazo de três 
meses. A proporção de mortes no prazo de três meses após o início do tratamento da TB aumentou substancialmente com a idade, de 8,8\% daqueles com idade entre 65 a 69 anos para 35,6\% das pessoas com 90 anos ou mais (TUBERCULOSIS SURVEILLANCE CENTER, 2016). Do mesmo modo ocorreu no Distrito Federal, onde o percentual de TB em idosos teve forte influência nos indicadores da enfermidade.

Outra questão importante é a sintomatologia da tuberculose que se apresenta no idoso, os sintomas por eles apresentados são atípicos, dada a dificuldades de interpretação do teste tuberculínico, achados radiológicos incomuns, e coexistem doenças ou diagnósticos alternativos frequentes, o que muitas vezes dificultam a identificação de TB antes da autópsia e contribuem para as altas taxas de mortalidade (CHAIMOWICZ, 2001; OLIVEIRA et al., 2013). Por sua vez, o intervalo entre as queixas iniciais e o diagnóstico da TB é maior em pessoas idosas e o resultado, em geral, mais grave (CHAIMOWICZ, 2001), além disso, requerem mais internações (OLIVEIRA, et al., 2013). A forma pulmonar é a mais presente em idosos (TUBERCULOSIS SURVEILLANCE CENTER, 2016).

As características clínicas da TB em adultos idosos por ser atípica podem ser confundidas com doença relacionada à idade. Por isso, o diagnóstico e tratamento de TB no idoso pode ser difícil e o tratamento associado às reações adversas aos medicamentos (RAJAGOPALAN, 2016). Por sua vez, estudo na Espanha entre os casos de tuberculose notificados no período de 2007 a 2012 em pessoas com idade acima de 65 anos mostraram também maior incidência de tuberculose extrapulmonar, apesar de uma tendência de queda dessa forma de TB em todas as faixas etárias (CULQUI-LÉVANO, RODRIGUEZ-VALÍN, DONADO-CAMPOS, 2016).

Adicionalmente, pessoas de mais idade tem dificuldade em acessar os serviços de saúde (YIMER; BJUNE; ALENE, 2005), por questões de interpretação e leitura da situação de saúde que ocorre consigo. Além disso, como tomam diferentes tipos de medicação, inclusive para outras enfermidades, existe uma tendência de relacionarem os sinais e sintomas de tuberculose as reações aos usos dos fármacos (CHAIMOWICZ, 2001). Por fim, o retardo no diagnóstico da TB pode envolver o sistema de saúde, dentre eles a dificuldade de acesso; acolhimento inadequado do doente; baixa prioridade na procura de sintomáticos respiratórios (SR) e de contatos intradomiciliares; baixo nível de suspeição diagnóstica de TB, correspondendo ao aumento do período entre a primeira visita ao serviço de saúde e o início do tratamento antituberculose (OLIVEIRA et al., 2013). Tais situações também favorecem e afastam o 
diagnóstico e o tratamento precoce da tuberculose, sendo que a participação dessas pessoas em outras atividades precisa ser considerada pelos serviços de saúde (OLIVEIRA et al., 2013).

Em relação ainda ao idoso, outro aspecto importante é a locomoção que na maioria das vezes se encontra comprometida em pacientes com tuberculose. Deve-se esclarecer que no Distrito Federal as distâncias entre as cidades são espacialmente grandes, e dentro do próprio território, denotando a importância deste aspecto na assistência ao idoso com TB. Os dados encontrados neste estudo revelaram que a média da distância percorrida pelo paciente entre a Unidade de Saúde e o local de residência no Distrito Federal foi de 1.503 metros. Souza et al. (2015), ao analisar a acessibilidade dos doentes de TB no Nordeste do Brasil, considerou acesso quando a distância percorrida de casa ao serviço de saúde for maior que 800 metros.

Assim apesar das ações de diagnóstico e controle da TB terem sido descentralizadas para a atenção básica no Distrito Federal, ela se encontra limitada em termos de quantitativo de unidades de saúde, para que sejam viabilizadas a assistência ao paciente com tuberculose, inclusive com disposição efetiva e participação dos profissionais envolvidos. É preciso que os profissionais que atuam nos serviços da atenção básica sejam qualificados para exercer seu papel, pois a falta de conhecimento por parte destes relaciona-se a falhas na detecção precoce dos sintomáticos respiratórios bem como na definição do diagnóstico (OLIVEIRA et al., 2013), inclusive nos idosos. Deve ser reforçado aqui o acesso dos suspeitos e doentes de tuberculose na Estratégia da Saúde da Família, como porta de entrada à assistência aos doentes de TB (BRASIL, 2011a).

O maior risco de adquirir a enfermidade nos idosos, em 2003, foi em São Sebastião seguido de Santa Maria e Sobradinho, que apresentou duas vezes mais em pessoas maiores de 60 anos de vida quando comparado ao da população geral do Distrito Federal (DISTRITO FEDERAL, 2004).

Em 2010, o grupo de idosos apresentou o maior risco de adoecimento de tuberculose na população em geral e a regional mais afetada foi Brazlândia, que está entre as regionais mais antigas do DF, seu histórico vem de antes da criação de Brasília, onde já existia como municípios do Estado de Goiás. (DISTRITO FEDERAL, 2012a).

Posteriormente, observou-se que houve uma modificação no perfil do doente de tuberculose, particularmente entre 2011 e 2012, onde a doença se concentrou nos grupos etários de adultos jovens e adultos. Por um lado, deve-se a menor proporção de idosos na população 
em geral e a maior prevalência de infecção neste grupo etário. Por outro lado, esta situação é resultado da maior proporção de jovens nos países em desenvolvimento com maior risco anual de infecção, como o Distrito Federal, onde apenas $12,77 \%$ da população vive para além da idade de 60 anos. Portanto, fatores demográficos (crescimento demográfico e envelhecimento) devem ser modificados com o impacto de fatores epidemiológicos (epidemia de HIV, programas de intervenção) (CHAIMOWICZ, 2001).

Cabe ressaltar a enorme implicação social e econômica da tuberculose acometer a população ativa, pois, ao atingir esse segmento social afeta do ponto de vista da previdência social/aposentadoria precoce, pelas sequelas e morte advindas da TB. O aumento de adoecimento para o grupo etário que é responsável pela força de trabalho foi relatado pela literatura e em situação epidemiológica similar à do DF, como na Espanha (63,6\%) e Hungria $(72,8 \%)$ (WHO, 2015), com concentração da TB em menores de 60 anos. (TOURAY et al., 2010; SANDGREN et al., 2012; WHO, 2015).

Em 2011 e 2012, as regionais de saúde que apresentaram um maior risco de adoecimento por tuberculose na população de 25 e 59 anos foram a de Paranoá, Gama, Planaltina e Ceilândia. Segundo os dados do PDAD (2011), as regiões apresentam características similares, com predomínio da população jovem onde mais de $40 \%$ da população está entre faixa etária de 25 a 59 anos (DISTRITO FEDERAL, 2011).

Sobretudo, a mudança do perfil epidemiológico do idoso para a população adulta jovem e adulta pode estar ligada à migração de pessoas para grandes núcleos urbanos como o Distrito Federal, onde $51,9 \%$ dos seus residentes são migrantes e $48,1 \%$, nativos (DISTRITO FEDERAL, 2012). Desde a criação de Brasília, em 1960, o grande objetivo do então presidente Juscelino Kubitschek era transferir a capital do Brasil do Rio de Janeiro para o Distrito Federal, dada a localização da região Centro-Oeste se encontrar numa área pouco desenvolvida, e, ao contrário, estimular o desenvolvimento regional, ser polo de integração nacional e sede da administração nacional (CAIADO, 2005). Neste sentido, com a construção da capital, houve uma migração intensa de trabalhadores, oriundos do nordeste $(51,0 \%)$ e sudoeste $(27,6 \%)$ do país (DISTRITO FEDERAL, 2012), que são locais de alta carga de TB (BRASIL, 2015), pela grande oferta de trabalho, sendo que a maioria de adultos se inseriu na construção civil. Fica evidente, então, que essa população migrante da época da construção, após 40 anos, ficou idosa e parte dela desenvolveu a tuberculose no Distrito Federal. 
Adicionalmente, no plano urbanístico da nova capital estava previsto a criação do Plano Piloto (sede do governo) e cidades satélites como núcleo periférico ao Plano Piloto, conforme necessidade de fixação da população (QUEIROZ, 2010). No entanto, com o início das obras, ocorreram diversas invasões de terrenos que não estavam previstas no plano original, com isso, houve a necessidade de criação de novos núcleos habitacionais paralelamente a cidade de Brasília. Primeiramente, foi criado o Núcleo Bandeirante, em 1956, para abrigar os trabalhadores que vieram construir Brasília. Secundariamente, em 1957, surgiu o Paranoá para receber os que iriam construir a barragem do Lago Paranoá. Por último, várias outras áreas foram surgindo no DF e, a partir de 1964, com o intuito de facilitar a administração desses locais, o Distrito Federal foi dividido em regiões administrativas (DISTRITO FEDERAL, 2012). Desde então, o Distrito Federal vem criando novas áreas e espaços urbanos e hoje se encontra como o $5^{\circ}$ maior núcleo populacional do país, considerando os maiores municípios do Brasil (BRASIL, 2016). Entretanto, o plano de Saúde de Bandeira de Melo previa um modelo assistencial para 500 mil pessoas no ano de 2000 (MELO, 1959; GÖTTEMS, 2009); porém, o Distrito Federal apresentou uma população quatro vezes maior do que o esperado para esse ano (BRASIL, 2016b). Enfim, o modelo assistencial proposto foi insuficiente para abrigar seus usuários, ele precisa ser resolutivo e sustentável, incluindo novas unidades de saúde capazes de atender a explosão demográfica que o Distrito Federal vem enfrentando ao longo da sua trajetória (GÖTTEMS, 2009). Isso corrobora com o verificado no estudo, que as unidades de saúde se mantiveram, quantitativamente, semelhantes durante os dez anos analisados.

Entretanto, como centro urbano de grandes potencialidades de emprego e renda (DISTRITO FEDERAL, 2012), o Distrito Federal chama a atenção de migrantes desde a sua construção, sendo que essa mesclagem de migrantes adultos e jovens nativos começa a fazer parte de novo cenário demográfico do DF, implicando em impacto nos dados demográficos e consequentemente epidemiológicos da TB. É tanto, que os achados nesse estudo mostraram, nos dois últimos anos, evidente mudança do perfil epidemiológico da tuberculose do idoso que migrou para a população adulta jovem e adulta. Cabe esclarecer que o mercado de trabalho do Distrito Federal é eminentemente público, que requer qualificação para se estabelecer no emprego público, e parte desses migrantes apresentam baixa escolaridade e se estabeleceu nas áreas de maior vulnerabilidade social, favorecendo provavelmente o adoecimento por tuberculose.

Na última década, a cidade do Paranoá recebeu parte dos migrantes do Distrito Federal, sendo que a maioria se concentrou no Itapuã, que pertence a regional do Paranoá, bem como 
no SCIA (Estrutural) ligada à regional do Guará e em São Sebastião. (DISTRITO FEDERAL, 2013). A Estrutural e o Itapoã estão entre as regiões de menor poder aquisitivo do DF com renda média de 2,32 SM a SCIA-Estrutural e 2,49 SM no Itapoã. São populações jovens, sendo mais de $30 \%$ crianças, quando desagregada a naturalidade, prevalece a população oriunda da Nordeste, na SCIA - Estrutural com 69,38\% e Itapoã 67,79\% vivendo em condições favoráveis ao adoecimento (DISTRITO FEDERAL, 2011).

Cabe esclarecer que entre os principais motivos da migração para o Distrito Federal, destacam-se o acompanhamento de familiares e a procura de trabalho, sendo que o item acompanhar parentes refere-se, principalmente, aos filhos que chegaram na companhia dos pais (DISTRITO FEDERAL, 2013). Assinala-se que a condição social desses migrantes sofre influência, particularmente, da economia, da origem e da localização geográfica do migrante (GILBERT et al., 2009; PLOUBIDIS et al., 2012). Desse modo, as condições de saúde se encontram relacionadas à origem destas pessoas que migram e, em geral, também são oriundas de áreas de alta carga de tuberculose, com posterior adoecimento dessa enfermidade no Distrito Federal.

Quanto à análise espacial de casos novos de TB ao longo dos 10 anos do estudo, observou-se que houve migração da intensidade dos casos da enfermidade para dois novos núcleos populacionais, além dos casos de TB se mostrarem mais próximos no Paranoá e São Sebastião, com significado estatístico. No Paranoá de 2003 a 2012, a proximidade dos doentes de TB saltou de um IDW=6,4 para 13,9 pacientes convivendo próximos. Cabe esclarecer que a regional Paranoá incluiu Itapuã, cujo novo assentamento mostrou um crescimento populacional de 21,9\% no período; além disso, a regional apresenta uma população com menos de 8 anos de estudo (53,52\%), renda de 1,6 SM (GDF, 2012). Da mesma forma São Sebastião, que na análise espacial mostrou uma intensidade dos casos de TB de até IDW=6,4 doentes em 2003, para IDW=13,9 casos em 2012. São Sebastião teve sua população incrementada em 17,0\%, e, posteriormente, parte das invasões de áreas públicas do DF foiremovida para esse local. Cerca de 40,4\% da sua população tem menos de oito anos de estudo e renda de 1.12 SM (GDF, 2014), ou seja, ambas regionais com limitações sociais. A maioria dos moradores dessas regionais possui casas próprias, em terrenos não legalizados com até dois dormitórios, cinco cômodos (49,2\%), numa área construída de 61 a $90 \mathrm{~m}^{2}$ (38,6\%) e em média residem 4,0 pessoas por domicílio, superior a média do DF que é de 3,3 pessoas/domicilio (Distrito Federal, 2014). 
Diversos estudos mostram a determinação social associada à produção da TB na população, tais como o da Noruega (STORLA; YIMER; BJUNE, 2008) que assinalou estreita relação da TB e as desigualdades sociais, com maior acometimento de pacientes em área rual, baixo acesso às unidades de tratamento (barreiras geográficas ou psicossociais) e em grupos de riscos, como idosos e pobres. Os estudos também revelaram forte associação da TB com imigrantes (CRESWELL et al; 2011; LÖNNROTH et al., 2014), baixo nível educacional (TOLLEFSON et al., 2013), consequentemente, pouca compreensão sobre a TB, o autotratamento e estigma (FUADY, PAKASI, MANSYUR, 2014). Estes ambientes pequenos, mal ventilados, sem penetração de luz solar e com maior agrupamento de pessoas favorece a transmissão de TB, como descrito no sul da Holanda (DE VRIES et al., 2010) e em Buenos Aires (HERRERO et a., 2015), o que permite uma compreensão de um contexto de TB, ligada à pobreza e miséria como a encontrada no DF.

Observou-se uma queda na cura da TB no DF durante o período analisado. É possível que as comorbidades como a diabetes mellitus, pessoas vivendo com HIV/AIDS, doenças mentais, bem como a questão de estilo de vida, devido ao abuso de álcool, tabaco e outras drogas (ZUMLA et al., 2012), problemas dos serviços de saúde, como falhas no uso da estratégia do Tratamento Diretamente Observado e na oferta de incentivos sociais (BRASIL, 2011b) devem ter sido envolvidos na queda da adesão do tratamento de TB no DF (DISTRITO FEDERAL, 2014). Estudos europeus mostraram que as comorbidades colocam as pessoas em maior risco de desenvolver TB, especialmente em pobres (UYEMURA; CASTLE; MAKINODAN, 2002). Além disso, são várias as dificuldades na condução do tratamento da TB em portadores de comorbidades, portanto, isso pode ter tido reflexo na cura (BRASIL, 2015). Além disso, a distância percorrida pelo doente de tuberculose à unidade de saúde requeria um custo financeiro e, como existe a recomandação de o paciente tomar o medicamento diariamente sob observação (BRASIL, 2011), provavelmente, essa estratégia não foi viabilizada, contribuindo para um desfecho desfavorável do tratamento em áreas menos abastadas do DF.

A acessibilidade dos serviços de saúde é imprecindível para o atendimento, tratamento e acompanhamento de qualquer agravo pelo serviço de saúde (STARFIELD, 2002), não diferentemente para a tuberculose, cujo tratamento é de 6 meses (BRASIL, 2011a). Neste sentido, no presente estudo, apesar de não ter mostrado a associação da distância com a cura, este aspecto pode ter sido um fator que dificultou a acessibilidade do paciente ao tratamento da tuberculose. A forma de deslocamento utilizada pelo indivíduo é fator que facilita ou dificulta 
o seu acesso ao serviço de saúde, sendo ele a primeira etapa a ser vencida pelo paciente que sai de casa em busca de atendimento para atender as suas necessidades físicas e psicológicas (RAMOS; LIMA, 2003).

Outra questão do acesso diz respeito aos contatos dos doentes de tuberculose que necessitam que identifique a infecção latente de tuberculose ou a doença ativa, como se encontra recomendado pelo Programa Nacional de Controle da Tuberculose (BRASIL, 2011a). Nestes casos, se o acesso não for facilitado aos contatos de portadores de TB, fica mantida a transmissão da doença na comunidade (BRASIL, 2011a). Daí a questão da distância, da falta de recursos da comunidade para tal avaliação, pode ter afetado de alguma forma a cura em algumas regionais de saúde. Um estudo sobre acessibilidade nos EUA mostrou que a desigualdade no acesso aos cuidados de saúde leva a disparidades nos resultados de saúde, incluindo a mortalidade e as complicações de doenças (WANG, 2012).

A distância média percorrida pelo paciente entre a sua residência e a unidade para tratamento de TB no DF foi de 1.500 metros. Portanto, é distante, e considera-se serviço acessível quando o paciente percorre até 800 metros para realizar o acompanhamento do caso (STARFIELD, 2002; HERRERO et al., 2015; SOUZA et al., 2015). Nesta casuística, não houve correlação entre a distância percorrida pelo paciente e a cura. O DF em 2003 referiu 88 unidades de saúde, em 2012, 94 unidades para atender TB; isto é, em dez anos houve um aumento de $6 \%$ e um crescimento populacional do DF de 19,7\%, ou seja, o programa de TB além de distante dos doentes, não acompanhou a demanda populacional, dificultando provavelmente o acesso. Essa pode ser uma das justificativas para o resultado negativo de cura da TB em algumas regionais no período (Recanto das Emas, 82,5\% e Santa Maria, 78,1\%), ambas as regionais sem ampliação de serviço de TB nos últimos 10 anos. A OMS recomenda sobretudo cura acima de 85,0\% (WHO, 2015) e para a acessibilidade ao serviço de TB essa ausência de ponto assistencial remete à falta de atenção à saúde ao paciente, daí os sujeitos não obtêm atendimento ou adiam o cuidado (STARFIELD, 2002), abandonam o tratamento e mantêm a transmissão da TB. Embora, na análise dos dados da pesquisa, a cura não tenha mostrado correlação significativa com a distância, verificou-se que o paciente percorreu uma distância maior do que o estimado pela literatura para obter um atendimento no setor saúde, e, isso possivelmente pode estar dificultando o acesso do enfermo ao serviço de saúde e refletindo na cura da TB, que sofreu uma redução nos últimos anos analisados. 
A literatura é vasta sobre o tema, e assinala que as condições de vida, habitação, trabalho, renda, educação e acesso aos serviços públicos são barreiras aos cuidados de saúde e que o conhecimento sobre a distribuição da doença de acordo com as características da população permite o desenvolvimento de estratégias de intervenção pelos programas de tuberculose locais, que deve ir além da questão operacional, mas deve considerar aspectos culturais, dados epidemiológicos (CASTRO et al., 2016), comportamentais e de estilo de vida.

Também, em pesquisa com distribuição espaciais e correlatos sociais e econômicos da tuberculose no Brasil, entre 2002 e 2009, utilizando dados de notificação de tuberculose por município, houve registro de taxas muito fortemente autocorrelacionadas ao espaço, sendo mais elevadas em áreas urbanas na costa leste e oeste do país. As análises de regressão ecológica não-espacial encontraram taxas mais altas associadas com a urbanização, densidade populacional, más condições econômicas, aglomeração familiar, em população não-branca e onde os indicadores de saúde eram piores. Apesar de um modelo estatístico utilizado, o efeito da pobreza apareceu parcialmente confundido por urbanicidade, raça e autocorrelação espacial, e parcialmente mediado pela aglomeração domiciliar. A análise destaca múltiplas relações entre os fatores socioeconômicos e a tuberculose no Brasil, e a importância de levar em consideração os fatores espaciais na análise dos determinantes socioeconômicos da tuberculose (HARLING; CASTRO, 2014).

Estudo realizado na Etiópia, com determinantes sociais em coinfectados (TB/HIV) e mortalidade, mostrou que 20,2\% dos pacientes morreram durante o período de estudo, e a análise de regressão logística mostrou que os fatores significativamente associados à mortalidade na co-infecção TB/HIV eram: ser trabalhador do sexo, acamados funcionalmente e residente em área rural. Ou seja, os determinantes sociais, incluindo o tipo de ocupação, gravidade da doença e residentes em área rural tiveram um desfecho ruim e ligado à doença de pobre. Enfim, os resultados deste estudo mostram o papel que os determinantes sociais desempenham em influenciar a mortalidade devido à coinfecção TB/HIV (GESESEW et al., 2016).

Os dados demonstraram que em nenhuma regional de saúde do DF a carga da TB mostrou-se elevada e ou próxima à média nacional, mas quase metade da nacional (BRASIL, 2016) e associada a limitações sociais. Observa-se, entretanto, que há grandes desigualdades internas no DF quando comparados os resultados entre as regionais de saúde. O risco de adoecer de TB na regional Paranoá foi duas vezes maior do que a Norte. Os homens foram os mais 
acometidos pela TB no DF, semelhante a diferentes estudos nacional e internacional, por exemplo, entre eles o de Goiás (BRASIL, 2014b) e Iran (YAZDANI-CHARATI et al., 2014). A enfermidade afetou mais a população entre 25 e 59 anos $(69,2 \%)$, que é responsável pela força de trabalho, da mesma forma que a observada na literatura e em situação epidemiológica similar a do DF, como na Espanha (63,6\%) e Hungria (72,8\%) (WHO, 2015), com concentração da TB em menores de 60 anos. (TOURAY et al., 2010; SANDGREN et al., 2012; WHO, 2015). Como a maior carga da TB no DF foi em locais mais pobres, provavelmente, a justificativa da TB não acometer mais idosos é de que eles vivem menos, resultando em menor incidência de TB nesse grupo; corroborado também pela representação dos mais velhos naquelas regiões, que são 9,7\% da população geral (DISTRITO FEDERAL, 2012a). 


\section{CONCLUSÃO}

Após análise dos dados, foi possível verificar que, em áreas de baixa incidência da tuberculose como o Distrito Federal, os casos dessa enfermidade estão centrados em bolsões de pessoas vulneráveis. Foram analisados 3.282 casos novos de TB registrados no SINAN do Distrito Federal em 10 anos de observação e houve uma redução de 2,2\% da incidência de TB no DF entre 2003 e 2012.

Houve predomínio da tuberculose no sexo masculino no período de análise, com maior incidência de TB em 2003. O sexo feminino mostrou um coeficiente de incidência com variação significativa ao longo dos dez anos, porém com tendência a decréscimo.

A região de saúde de São Sebastião apresentou maior incidência de TB, sendo que o número de casos do sexo masculino foi nove vezes maior quando comparado às mulheres. Houve variações significativas em relação ao número de casos de tuberculose por sexo entre as regionais de saúde do Distrito Federal (Sul, Taguatinga, Sobradinho, Planaltina, Santa Maria).

Considerando o grupo etário, as maiores incidências de casos de TB foram encontradas entre os idosos (60 anos ou mais) nos oito primeiros anos (2003 a 2010), passando a ser maior em adultos (25 a 59) a partir de 2011. Ressalta-se também que entre as regionais de saúde, observou-se padrões distintos de coeficientes de incidência por faixas etárias, oscilando entre os adultos de 25 a 59 anos e os idosos, como observado no conjunto dos dados do período.

$\mathrm{Na}$ análise do coeficiente médio de incidência, a regional de saúde do Paranoá apresentou o maior CMI e a Norte o menor coeficiente. Em todo o período de estudo, foi observado que a regional de saúde do Guará teve a menor incidência de TB, excluindo a Estrutural. Houve também redução na incidência de TB no DF na regional de saúde da Asa Norte, Taguatinga e Samambaia no decorrer dos 10 anos de análise. No Núcleo Bandeirante, observou-se um aumento anual da incidência de tuberculose de 5,5\%. Não foram observadas diferenças significativas nas incidências de TB nas regionais do Guará, Brazlândia, Planaltina, São Sebastião e Paranoá. As regionais de Santa Maria, Núcleo Bandeirante, Samambaia, Sobradinho, Planaltina, Recanto das Emas, Guará e Paranoá obtiveram os maiores CMI de TB, durante o período analisado, mostrando que estas áreas têm um risco maior de ocorrer o adoecimento por TB. 
Durante o período do estudo analisado, o coeficiente de incidência de tuberculose apresentou decréscimo de 2003 a 2006, aumento em 2007, redução subsequente de 2007 a 2011 , seguida de crescente em 2012.

A taxa de cura no DF diminuiu de 2003 (90,2\%) para 2012 (81,8\%). Algumas regionais, como a Sul, Brazlândia, Paranoá e São Sebastião chegaram a obter 100\% de cura em 2003, porém, apenas a regional de saúde de Sobradinho atingiu esse percentual em 2012.

As regionais que obtiveram as melhores taxas médias de cura foram a Sul, Núcleo Bandeirante, Ceilândia e Planaltina. A proporção de cura média no DF, no período estudado, foi $88,6 \%$.

Houve associação significativa entre o coeficiente de incidência de TB e todos os indicadores sociais, exceto a taxa de cura. Ou seja, a medida em que se eleva a taxa de fecundidade, o percentual de pessoas com ocupação do lar, a taxa de violência, a taxa de mortalidade e a proporção de analfabetos, o coeficiente de incidência de tuberculose aumenta e, ao contrário, quando eleva-se a taxa de envelhecimento e a renda, o coeficiente de TB diminui.

Houve significativa associação dos indicadores de determinantes sociais com o coeficiente de incidência da TB em diferentes regionais como: mortalidade em Sobradinho, violência em Brazlândia e Gama, envelhecimento em Taguatinga e Paranoá e fecundidade no Paranoá e Gama. O indicador de cura não mostrou associação significativa com o coeficiente de incidência em nenhuma regional de saúde.

Em relação ao acesso aos serviços de saúde, a distância percorrida em metros pelo paciente entre a sua residência e a unidade de tratamento de tuberculose variou consideravelmente. A menor distância percorrida pelo paciente de tuberculose foi de 100 metros e a maior, 10.497 metros. A medida em que aumentou a taxa de cura, também se ampliou a distância percorrida. As localidades que apresentaram maior proximidade (intensidade) entre os pacientes e as unidades de tratamento dos casos de TB foram Santa Maria, Núcleo Bandeirante, Samambaia, Sobradinho, Planaltina, Recanto das Emas e Guará.

O inverso da distância ponderada foi identificado com mais intensidade (proximidade dos casos de TB) nas regionais de saúde de Santa Maria, Núcleo Bandeirante, Samambaia, Sobradinho, Planaltina, Recanto das Emas e Guará. Na comparação da TB entre 2003 e 2012, duas regionais mostraram maior proximidade (intensidade) dos doentes de tuberculose em 
2012, as regionais de saúde do Paranoá e São Sebastião. A distribuição espacial da TB foi semelhante nas demais regionais no período analisado.

Como limitações do estudo estão o uso de bases secundárias do SINAN-TB, uma vez que as informações, por vezes, podem ser inconsistentes devido a registros incompletos e/ou em branco e também à ausência de dados demográficos e sociais anuais, o que levou a calcular estimativas, podendo não inferir na realidade local.

Novas pesquisas devem explorar o planejamento de ações junto à Estratégia Saúde da Família, uma vez que a atenção básica seria a porta de entrada mais solidária e justa destas pessoas ao sistema de saúde. Também seria necessário estudar em cada território como cada determinante social é capaz de implicar em maior adoecimento ou não da doença tuberculosa, analisar espacialmente a distribuição da tuberculose nas regionais de saúde mais afetadas, associando as informações geográficas aos fatores sociais. Do mesmo modo, deve-se verificar se os incentivos sociais estatais estão sendo acessados por estas pessoas com tuberculose, uma vez que a doença está ligada à pobreza e miséria.

Além disso, os resultados do estudo podem subsidiar gestores na criação de estratégias de atuação nas áreas de risco, com concentração de esforços para reduzir sofrimento das pessoas afetadas e custos financeiros, otimizar recursos humanos, laboratoriais para o diagnóstico e tratamento da TB, além de apoio logístico para alcançar mais rapidamente a pré-eliminação da TB no Distrito Federal.

Enfim, as estruturas de intervenção que abordam tuberculose e as outras comorbidades associadas incluindo a infecção HIV, diabetes e a mortalidade por essa causa não devem incidir apenas sobre as intervenções médicas da doença, mas devem também integrar e melhorar os determinantes sociais das populações afetadas. 


\section{REFERÊNCIAS}

ACOSTA, L. M. W.; BASSANESI, S. L. O paradoxo de Porto Alegre: os determinantes sociais e a incidência da tuberculose. Revista brasileira de epidemiologia, São Paulo, v. 17, n. 2, p. 88-101, 2014.

ALI, M. Treating tuberculosis as a social disease. The Lancet, v. 383, n. 9936, p. 2195, 2014.

ALMEIDA, C. S. et al. Avaliação de novos antígenos de Mtb para vacinação e imunodiagnóstico precoce da TB. Principia: Caminhos da iniciação científica, v. 10, p. 97$106,2005$.

ALVES, R. S. et al. Abandono do tratamento da tuberculose e integralidade da atenção na estratégia saúde da família. Texto \& Contexto-Enfermagem, v. 21, n. 3, p. 650-657, 2012. Disponível em <http://www.scielo.br/scielo.php?script=sci_arttext\&pid=S0104$07072012000300021 \& \operatorname{lng}=$ pt\&nrm=iso > . Acesso em: 18 abr. 2015.

APARICIO, C.; BITENCOURT, M. D. Modelagem espacial de zonas de risco da leishmaniose tegumentar americana. Rev. Saúde Pública, São Paulo, v. 38, n. 4, p 511-516, ago. 2004.

AYRES, J. R. C. M. Sujeito, intersubjetividade e práticas de saúde. Ciência e saúde coletiva, v. 6, n. 1, p. 63-72, 2001.

AZHAR, G. S. et al. DOTS for TB relapse in India: A systematic review. Lung India, v. 29, n. 2, p. 147, 2012.

BARCELLOS, C.; BASTOS, F. I. Geoprocessamento, ambiente e saúde: uma união possível?. Cad. Saúde Pública, Rio de Janeiro, v. 12, n. 3, p.389-397, jul/set. 1996.

BARROSO, E. C. et al. Fatores de risco para tuberculose multirresistente adquirida. J Pneumol, v. 29, n. 2, p. 89-97, 2003.

BONACCI, R. A. et al. Impact of cigarette smoking on rates and clinical prognosis of pulmonary tuberculosis in Southern Mexico. Journal of Infection, v. 66, n. 4, p. 303-312, 2013.

BRASIL. Instituto Brasileiro de Geografia e Estatística. Geociências. 2016. Disponível em:<http://downloads.ibge.gov.br/downloads_geociencias.htm>. Acesso: 10 abr. 2016.

Ministério da Saúde. Departamento de Informática do SUS / DATASUS.

Departamento de Estatística do SUS / TABNET. Período 2003 a 2012. Casos novos

tuberculose (todas formas) Distrito Federal. Brasília: Editora do Ministério da Saúde; 2015. Disponível em: http://tabnet.datasus.gov.br/cgi/tabcgi.exe?idb2012/d0202.def. Acesso em 20 jul 2016.

Ministério da Saúde. Secretaria de Vigilância em Saúde. Boletim Epidemiológico. v. 46, n. 9, 2015. Disponível em: <http://u.saude.gov.br/images/pdf/2015/marco/25/Boletimtuberculose-2015.pdf> Acesso em: 04 jul. 2015. 
Ministério da Saúde. Secretaria de Vigilância em Saúde. Departamento de Vigilância das Doenças Transmissíveis. Técnicas de aplicação e leitura da prova tuberculínica / Ministério da Saúde, Secretaria de Vigilância em Saúde, Departamento de Vigilância das Doenças Transmissíveis. - Brasília: Ministério da Saúde, 2014a.

Ministério da Saúde. Secretaria de Vigilância em Saúde. Boletim Epidemiológico. O controle da tuberculose no Brasil: avanços, inovações e desafios. v. 44, n. 2. Brasil, 2014 b.

Ministério da Saúde. Secretaria de Vigilância em Saúde. Departamento de Vigilância Epidemiológica. Manual de recomendações para o controle da tuberculose no Brasil. Brasília: Ministério da Saúde, 2011a.

Ministério da Saúde. Secretaria de Vigilância em Saúde. Departamento de Vigilância Epidemiológica. Tratamento diretamente observado (TDO) da tuberculose na atenção básica: protocolo de enfermagem. Brasília: Ministério da Saúde, 2011 b.

Ministério do Desenvolvimento Social e Combate à Fome. Política Nacional do Idoso: Lei n⿳0 8.842, de janeiro de 1994. ed. 1, Brasília, 2010.

Ministério da Saúde. Secretaria de Atenção à Saúde. Departamento de Ações Programáticas e Estratégicas. Política Nacional de Atenção Integral à Saúde do Homem: princípios e diretrizes / Ministério da Saúde, Secretaria de Atenção à Saúde, Departamento de Ações Programáticas e Estratégicas - Brasília: Ministério da Saúde, 2008.

. Ministério da Saúde. Secretaria de Vigilância em Saúde. Fundação Oswaldo Cruz. Introdução à Estatística Espacial para a Saúde Pública / Ministério da Saúde, Fundação Oswaldo Cruz; Simone M. Santos, Wayner V. Souza, organizadores. - Brasília: Ministério da Saúde, 2007.

Ministério da Saúde. Secretaria Executiva. Departamento de Apoio à

Descentralização. Coordenação-Geral de Apoio à Gestão Descentralizada. Diretrizes operacionais dos Pactos pela Vida, em Defesa do SUS e de Gestão. Ed. MS - OS, 2006. Disponível em: <http://conselho.saude.gov.br/webpacto/volumes/01.pdf>. Acesso em: 15 abr. 2015.

Ministério da Saúde. Secretaria de Vigilância em Saúde. Guia de vigilância epidemiológica. Brasília: Ministério da Saúde, 2005.

BURRILL, J. et al. Tuberculosis: A Radiologic Review. Radiographics, v. 27, n. 5, p. 12551273, 2007.

BURROUGH, P. A.; MCDONNELL, R. A. Principles of geographical information systems. London: Oxford, 1998.

BUSS. P. M.; PELLEGRINI-FILHO, A. A Saúde e seus Determinantes Sociais. Physis: Revista de Saúde Coletiva, Rio de Janeiro, v. 17, n. 1, p.77-93, 2007.

BUSSAB, W. O.; MORETTIN, P. A. Estatística Básica. 8. ed. São Paulo: Saraiva, 2013.

CAIADO, M. C. S. Estruturação intra-urbana na região do Distrito Federal e entorno: a mobilidade e a segregação socioespacial da população. Revista Brasileira de Estudos de População, São Paulo, v. 22, n. 1, p. 55-88, 2005. 
CÂMARA, G.; DAVIS, C.; MONTEIRO, A. M.V. Introdução à ciência da geoinformação. São José dos Campus, INPE, 2001.

CAMARGO, C. G. E.; DRUCK, S.; CÂMARA, G. Análise de Superfícies por Geoestatística Linear. Análise espacial de dados geográficos. Brasília: EMBRAPA, p. 79-122, 2004.

CAMPINAS, L. L. S. L.; ALMEIDA, M. M. M. B. Agentes Comunitários de Saúde e o acolhimento aos doentes com tuberculose no Programa Saúde da Família. Boletim de pneumologia sanitária, Rio de Janeiro, v. 12, n. 3, p. 145-154, 2004.

CARVALHO, A. L. B. de et al. A gestão do SUS e as práticas de monitoramento e avaliação: possibilidades e desafios para a construção de uma agenda estratégica. Ciência \& saúde coletiva, Rio de Janeiro, v. 17, n. 4, p. 901-911, 2012.

CASTRO, D. B. et al. The Socioeconomic Factors and the Indigenous Component of Tuberculosis in Amazonas. PloS one, v. 11, n. 6, p. e0158574, 2016.

CHAIMOWICZ, F. Transição etária da incidência e mortalidade por tuberculose no Brasil. Revista de Saúde Pública, São Paulo, v. 35, p. 81-87, 2001.

CHAN, J.; FLYNN, J. The immunological aspects of latency in tuberculosis. Clinical Immunology, v. 110, n. 1, p. 2-12, 2004.

CHIESA, A, M.; WESTPHAL, M. F.; KASHIWAGI, N. M. Geoprocessamento e a promoção da saúde: desigualdades sociais e ambientais em São Paulo. Revista de Saúde Pública, São Paulo, v. 36, n. 5, p.559-567, out. 2002.

COLDITZ, G. A. et al. The Efficacy of Bacillus Calmette-Guérin Vaccination of Newborns and Infants in the Prevention of Tuberculosis: Meta-Analyses of the Published Literature. Pediatrics, v. 96, n. 1, p. 29-35, 1995.

COMMISSION ON SOCIAL DETERMINANTS OF HEALTH (CSDH). A conceptual framework for action on the social determinants of health, 2007. Disponível:

<em:http://www.who.int/social_determinants/resources/csdh_framework_action_05_07.pdf>. Acesso em: 22 Ago 2010.

COURTENAY, W.H. Constructions of masculinity and their influence on men's welleing: a theory of gender and health. Social Science \& Medicine, v. 50, p. 1385-1401, 2000.

CRESWELL, J. et al. Tuberculosis and noncommunicable diseases: neglected links and missed opportunities. European Respiratory Journal, v. 37, n. 5, p. 1269-1282, 2011.

CULQUI-LÉVANO, D. R.; RODRIGUEZ-VALÍN, E.; DE MATA DONADO-CAMPOS, J. Analysis of extrapulmonary tuberculosis in Spain: 2007-2012 National Study. Enfermedades Infecciosas y Microbiología Clínica, 2016.

CUNHA, T. N.; QUINTANILHA, J. A.; SILVA, N. N. Amostra mestra e geoprocessamento: tecnologias para inquéritos domiciliares. Revista de Saúde Pública, São Paulo, v. 37, n. 4, p. 494-502, 2003.

CZERESNIA, D.; DE FREITAS, C. M. Promoção da saúde: conceitos, reflexões, tendência. SciELO-Editora Fiocruz, 2009 
DALCOLMO, M. P.; ANDRADE, M. K. N.; PICON, P. D. Tuberculose multirresistente no Brasil: histórico e medidas de controle. Revista de Saúde Pública, v. 41, p. 34-42, 2007. Disponível em: <http://www.scielo.br/scielo.php?script=sci_arttext\&pid=S003489102007000800006\&lng=pt\&nrm=iso > . Acesso em: 01 abr. 2015. (

DALEY, C. L.; GOTWAY, M. B.; JASMER, R. M. Radiographic manifestations of tuberculosis. A primer for clinicians. $2^{\mathrm{a}}$ ed. San Francisco: Curry International Tuberculosis Center, 2011.

DAVIES, P. D. O. Risk factors for tuberculosis. Monaldi archives for chest disease, v. 63, n. $1,2005$.

DE CARVALHO, J. A. M.; RODRÍGUEZ-WONG, L. L. The changing age distribution of the Brazilian population in the first half of the 21st century. Cadernos de saúde pública, v. 24, n. 3, p. 597-605, 2008.

DE KEIJZER, B. Hasta donde El cuerpo aguante: gênero cuerpo y salud masculina. La salud como derecho ciudadano: perspectivas y propuestas desde América Latina. Lima, Perú: Foro Internacional en Ciencias Sociales y Salud, p. 137-152, 2003.

DE VRIES, G. et al. Epidemiology of tuberculosis in big cities of the European Union and European Economic Area countries. Euro Surveill, v. 19, n. 9, 2014.

DE VRIES, G. et al. Factors associated with the high tuberculosis case rate in an urban area. The International Journal of Tuberculosis and Lung Disease, v. 14, n. 7, p. 859-865, 2010.

DIAS, M. C. F. S. et al. Distribuição espacial da hanseníase no município de Mossoró/RN, utilizando o Sistema de Informação Geográfica - SIG. An. Bras. Dermatol, v. 80, n. Supl 3, p. S289-94, 2010.

DIEL, R. et al. Old ideas to innovate tuberculosis control: preventive treatment to achieve elimination. European Respiratory Journal, v. 42, n. 3, p. 785-801, 2013.

DINIZ, D.; GUILHEM, D. Bioética feminista: o resgate político do conceito de vulnerabilidade. Revista Bioética, v. 7, n. 2, 2009.

DISTRITO FEDERAL. Governo do Distrito Federal. Diretoria de Vigilância Epidemiológica. Gerência de Doenças Crônicas e Outros Agravos Transmissíveis (GDECAT). Tuberculose DF: Boletim Informativo. Brasília: GDF, 2015a.

Governo do Distrito Federal. Companhia de Planejamento do Distrito Federal - CODEPLAN. Distrito Federal. 2015. Disponível em: http:<//http://www.codeplan.df.gov.br/>. Acesso em: 16 set. 2015 b.

Governo do Distrito Federal. Secretaria de Estado de Planejamento, Orçamento e Gestão. Companhia de Planejamento do Distrito Federal - Codeplan. Pesquisa Distrital por Amostra de Domicílios - Distrito Federal - PDAD/DF 2013. Brasília: Codeplan, 2014.

Governo do Distrito Federal. Secretaria de Estado de Planejamento, Orçamento e Gestão. Companhia de Planejamento do Distrito Federal - Codeplan. Pesquisa 
Distrital por Amostra de Domicílios - Distrito Federal - PDAD/DF 2011. Brasília: Codeplan, 2012.a

Governo do Distrito Federal. Secretaria de Estado de Saúde do Distrito Federal. Subsecretaria de Vigilância à Saúde - SVS. Diretoria de Vigilância Epidemiológica. População de pessoas residentes do DF, de acordo com a faixa etária, o bairro de residência e a unidade de atendimento - 2012. Brasília, GDF, 2012.b

Governo do Distrito Federal. Secretaria de Estado de Saúde do Distrito Federal. Subsecretaria de Vigilância à Saúde - SVS. Diretoria de Vigilância Epidemiológica. População de pessoas residentes do DF, de acordo com a faixa etária, o bairro de residência e a unidade de atendimento - 2003. Brasília, GDF, 2003.

DUARTE, E. C. et al. Epidemologia das desigualdades em saúde no Brasil: um estudo exploratório. Brasília: Organização Pan-Americana da Saúde, 2002.

FARGA, V., CAMINERO, J. A. Tuberculosis. Buenos Aires: Mediterraneo. 2011.

FERREIRA, A. A. A. et al. Os fatores associados à tuberculose pulmonar e a baciloscopia: uma contribuição ao diagnóstico nos serviços de saúde pública. Revista brasileira de epidemiologia, v. 8, n. 2, p. 142-149, 2005.

FIGUEIREDO, W. Assistência à saúde dos homens: um desafio para os serviços de atenção primária. Ciência \& Saúde Coletiva, v. 10, n. 1, p. 105-109, 2005.

FORD, N. et al. TB as a cause of hospitalization and in-hospital mortality among people living with HIV worldwide: a systematic review and meta-analysis. Journal of the International AIDS Society, v. 19, n. 1, 2016.

FUADY, A.; PAKASI, T. A.; MANSYUR, M. The social determinants of knowledge and perception on pulmonary tuberculosis among females in Jakarta, Indonesia. Medical Journal of Indonesia, v. 23, n. 2, p. 99, 2014.

GARNELO, L.; BRANDAO, L. C.; LEVINO, A. Dimensões e potencialidades dos sistemas de informação geográfica na saúde indígena. Revista de Saúde Pública, v. 39, n. 4, p. 634640, 2005.

GESESEW, H. et al. The role of social determinants on tuberculosis/HIV co-infection mortality in southwest Ethiopia: a retrospective cohort study. BMC research notes, v. 9, n. 1, p. 1, 2016.

GILBERT, R. L. et al. The impact of immigration on tuberculosis rates in the United Kingdom compared with other European countries. The international journal of tuberculosis and lung disease, v. 13, n. 5, p. 645-651, 2009.

GOMES, R. et al. Sexualidade masculina e saúde do homem: proposta para uma discussão. Ciência \& Saúde Coletiva, v. 8, n. 3, p. 825-829, 2003.

GÖTTEMS, L.B.D. et al. Trajetória da política de atenção básica à saúde no Distrito Federal, Brasil (1960 a 2007): análise a partir do marco teórico do neo-institucionalismo histórico. Cadernos de Saúde Pública, v. 25, n. 6, p. 1409-1419, 2009. 
GUILHEM, D.; AZEVEDO, A. F. Bioética e gênero: moralidades e vulnerabilidade feminina no contexto da Aids. Revista Bioética, v. 16, n. 2, 2009.

GUPTA, A. et al. Early mortality in adults initiating antiretroviral therapy (ART) in low-and middle-income countries (LMIC): a systematic review and meta-analysis. PloS one, v. 6, n. 12, p. e28691, 2011.

HARGREAVES, J. R. et al. The social determinants of tuberculosis: from evidence to action. American journal of public health, v. 101, n. 4, p. 654-662, 2011.

HARLING, G.; CASTRO, M. C. A spatial analysis of social and economic determinants of tuberculosis in Brazil. Health \& place, v. 25, p. 56-67, 2014.

HERRERO, M. B. et al. Social determinants of nonadherence to tuberculosis treatment in Buenos Aires, Argentina. Cadernos de saúde pública, v. 31, n. 9, p. 1983-1994, 2015.

HOSFORD, J.D. et al. Hepatotoxicity from antituberculous therapy in the elderly: a systematic review. Tuberculosis, v. 95, n. 2, p. 112-122, 2015.

INSTITUTO DE PESQUISA ECONÔMICA APLICADA (IPEA). Governança Metropolitana no Brasil. Brasília: Codeplan, 2013.

JEON, C. Y.; MURRAY, M. B. Diabetes mellitus increases the risk of active tuberculosis: a systematic review of 13 observational studies. PLoS Med, v. 5, n. 7, p. e152, 2008.

JIANG, J. et al. Smoking and risk of death due to pulmonary tuberculosis: a case-control comparison in 103 population centers in China. The International Journal of Tuberculosis and Lung Disease, v. 13, n. 12, p. 1530-1535, 2009.

KAWATSU, L.; ISHIKAWA, N. Socio-economic factors that influence tuberculosis death among the youth and middle-aged population: a systematic review. Kekkaku, v. 89, p. 547$54,2014$.

KRITSKI, A. L.; CONDE, M. B.; SOUZA, G. R. M. de. Tuberculose: do ambulatório à enfermaria. São Paulo, SP: Atheneu, 2005. 259 p. ISBN 8573797673

LAM, C. et al. Prevalence of tobacco smoking in adults with tuberculosis in South Africa [Short communication]. The International Journal of Tuberculosis and Lung Disease, v. 17, n. 10, p. 1354-1357, 2013.

LÖNNROTH, K. et al. Drivers of tuberculosis epidemics: the role of risk factors and social determinants. Social science \& medicine, v. 68, n. 12, p. 2240-2246, 2009.

LÖNNROTH, K. et al. Beyond UHC: monitoring health and social protection coverage in the context of tuberculosis care and prevention. PLoS Med, v. 11, n. 9, p. e1001693, 2014.

LÖNNROTH, K. et al. Towards tuberculosis elimination: an action framework for lowincidence countries. European Respiratory Journal, v. 45, n. 4, p. 928-952, 2015.

LOPES, A. C. Tratado de clínica médica. 3. ed. São Paulo, SP: Roca, 2015. 3 v. 
MACHADO, P. C. et al. Comparação do teste tuberculínico e do ensaio de liberação de interferon-gama para diagnóstico de tuberculose latente em agentes comunitários de saúde do Sul do Brasil, Rio Grande do Sul, 2012. Epidemiologia e Serviços de Saúde, v. 23, n. 4, p. 675-681, 2014. Disponível em: <http://www.scielosp.org/pdf/ress/v23n4/2237-9622-ress-2304-00675.pdf>. Acesso em: 23 mar. 2016.

MACIEL, E. L. N. et al. Delay in diagnosis of pulmonary tuberculosis at a primary health clinic in Vitoria, Brazil. The International journal of tuberculosis and lung diseases. v.14, n. 11, p. 1403-1410, 2010.

MARCOLINO, A. B. L. et al. Avaliação do acesso às ações de controle da tuberculose no contexto das equipes de saúde da família de Bayeux-PB. Revista Brasileira de

Epidemiologia, v. 12, n. 2, p. 144-157, 2009. Disponível em: < http://www.scielo.br/scielo.php?script=sci_arttext\&pid=S1415-790X2009000200005> Acesso em: 08 abr. 2015.

MATSUMOTO, K. et al. The association between smoking and sputum smear-positive pulmonary tuberculosis in Osaka City. Kekkaku: Tuberculosis, v. 87, n. 8, p. 541-547, 2012.

MEDRONHO, R. A. Epidemiologia. 2. ed. São Paulo: Atheneu, 2011. 685 p.

MELO, H. B. Plano Geral da Rede Médico-Hospitalar de Brasília. Revista do Serviço de Saúde Pública, v. 11, n. 1, 1959.

MERHY, E. E. Em busca da qualidade dos serviços de saúde: os serviços de porta aberta para a saúde e o modelo tecno-assistencial em defesa da vida. In: Saúde em Debate. Serie Didática. Hucitec, 1994. p. 117-60.

MILLET, J-P. et al. Factors that influence current tuberculosis epidemiology. European Spine Journal, v. 22, n. 4, p. 539-548, 2013.

MONROE, A. A. et al. Envolvimento de equipes da atenção básica à saúde no controle da tuberculose. Revista da escola de enfermagem da USP, v. 42, n. 2, p. 262-7, 2008.

Disponível em: < http://www.scielo.br/pdf/reeusp/v42n2/v42n2a7> Acesso em: 10 abr. 2015.

MONTEIRO, T. M. R; FIGUEIREDO, S. H.; DE ARAÚJO ASSISVI, M. M. Dificuldades de acesso a serviços de saúde para diagnóstico de tuberculose em municípios do Brasil. Revista de Saúde Pública, v. 43, n. 3, p. 389-97, 2009. Disponível em: <

http://www.scielo.br/scielo.php?pid=S0034-

89102009000300001\&script=sci_abstract\&tlng=pt> Acesso em: 10 abr. 2015

MOREIRA, M. A. C. et al. Avaliação da notificação no Distrito Federal de casos de tuberculose residentes em dez municípios goianos do entorno e análise da incidência de tuberculose nestas localidades. Jornal Brasileiro de Pneumologia, v. 33, n. 3, p. 301-310, 2007.

MOUTINHO, I. L. D. Tuberculose: aspectos imunológicos na infecção e na doença. 2011. Disponível em: < http://rmmg.org/artigo/detalhes/289>. Acessado em: 28 mar. 2016.

MUSSI, T.V.F.; TRALDI, M.C.; TALARICO, J.N.S. Knowledge as a factor in vulnerability to tuberculosis among nursing students and professionals. Revista da Escola de

Enfermagem da USP, v. 46, n. 3, p. 696-703, 2012. 
NARASIMHAN, Padmanesan et al. Risk factors for tuberculosis. Pulmonary medicine, v. 2013, 2013.

NARDI, A.; GLINA. S.; FAVORITO, L.A. Primeiro Estudo Epidemiológico sobre Câncer de Pênis no Brasil, International Braz J Urol, v. 33, p. 1-7, 2007.

NASRI, F. O envelhecimento populacional no Brasil. Einstein, v. 6, n. Supl 1, p. S4-S6, 2008.

NEVES, M. C. et al. Análise exploratória espacial de dados sócio-econômicos de São Paulo. GISBrasil2000, 2000. Disponível em:

http://www.dpi.inpe.br/gilberto/papers/marcos_gisbrasil2000.pdf. Acesso em 13 mai 2016

NORTH, R. J.; JUNG, Y. J. Immunity to tuberculosis. Annual Review of Immunology. v. 22, n. 1, p. 599-623, 2004.

OLIVEIRA, A. A. V. et al. Diagnóstico da tuberculose em pessoas idosas: barreiras de acesso relacionadas aos serviços de saúde. Revista da Escola de Enfermagem da USP, v. 47, n. 1, p. 145-151, 2013

PAI, M; RILEY, Lee W.; COLFORD, J. M. Interferon- $\gamma$ assays in the immunodiagnosis of tuberculosis: a systematic review. The Lancet infectious diseases, v. 4, n. 12, p. 761-776, 2004.

PEDNEKAR, M. S.; GUPTA, P. C. Prospective study of smoking and tuberculosis in India. Preventive Medicine, v. 44, n. 6, p. 496-498, 2007.

PEREIRA, M. G. Epidemiologia: teoria e prática. Rio de Janeiro, RJ: GEN: Guanabara Koogan, 2013.

PLOUBIDIS, G. B. et al. Social determinants of tuberculosis in Europe: a prospective ecological study. European Respiratory Journal, v. 40, n. 4, p. 925-930, 2012.

QUEIROZ, E.P. de. A migração intrametropolitana no Distrito Federal e Entorno: o consequente fluxo pendular eo uso dos equipamentos urbanos de saúde e educação. XV Encontro Nacional de Estudos Populacionais: 18-22 September 2006; Caxambú/MG, 2010.

RAJAGOPALAN, S. Tuberculosis in Older Adults. Clinics in Geriatric Medicine, v. 32, n. 3, p. 479-491. 2016.

RAMOS, D. D.; LIMA, M. A. D. S. Acesso e acolhimento aos usuários em uma unidade de saúde de Porto Alegre, Rio Grande do Sul, Brasil Health care access and receptivity to users in a unit in Porto Alegre, Rio Grande do Sul, Brazil. Cad. saúde pública, v. 19, n. 1, p. 27 34, 2003.

RANDREMANANA, R. V. et al. Spatial clustering of pulmonary tuberculosis and impact of the care factors in Antananarivo City. Tropical Medicine \& International Health, v. 14, n. 4, p. 429-437, 2009. 
REEVES, A. et al. Social protection and tuberculosis control in 21 European countries, 19952012: a cross-national statistical modelling analysis. The Lancet Infectious Diseases, v. 14, n. 11, p. 1105-1112, 2014.

RODRIGUES, J. et al. Aplicação dos testes IGRA na detecção de tuberculose latente: o geral e o particular. 2013.

ROUILLON, A.; PERDRIZET, S.; PARROT, R. Transmission of tubercle bacilli: the effects of chemotherapy. Tubercle, v. 57, p. 275-299. 1976

ROWIŃSKA-ZAKRZEWSKA, E. et al., What factors may influence epidemiological situation of tuberculosis in Poland and in the world?. Pneumonol Alergol Pol, v. 84, p. 126133. 2016.

SALGAME, P. Host innate and Th1 responses and the bacterial factors that control Mycobacterium tuberculosis infection. Current opinion in immunology, v. 17, n. 4, p. 374$380,2005$.

SÁNCHEZ, A. I. M.; BERTOLOZZI, M. R. Pode o conceito de vulnerabilidade apoiar a construção do conhecimento em Saúde Coletiva. Ciência \& Saúde Coletiva, v. 12, n. 2, p. 319-324, 2007.

SANCHINI, A. et al. Laboratory diagnosis of pediatric tuberculosis in the European Union/European Economic Area: analysis of routine laboratory data, 2007 to 2011. Euro Surveill, v. 19, 2014.

SANDGREN, A. et al. Complete republication: Epidemiology of tuberculosis in the EU/EEA in 2010 - Monitoring the progress towards tuberculosis elimination. European Journal of Microbiology and Immunology, v. 2, n. 4, p. 292-296, 2012.

SANTOS, J. Resposta brasileira ao controle da tuberculose. Revista de Saúde Pública, v. 41, n. suppl. 1, p. 89-93, 2007. Disponível em:

<http://www.scielo.br/scielo.php?script=sci_arttext\&pid=S003489102007000800012\&lng=en\&nrm=iso>. Acesso em 18 abr. 2015.

SÁ-SILVA, J. R.; DE ALMEIDA, C. D.; GUINDANI, J. F. Pesquisa documental: pistas teóricas e metodológicas. Revista Brasileira de História \& Ciências Sociais, v. 1, n. 1, 2015.

SCATENA, L. M. et al. Dificuldades de acesso a serviços de saúde para diagnóstico de tuberculose em municípios do Brasil. Revista de Saúde Pública, São Paulo, v. 43, n. 3, p. 389-397, jun. 2009. Disponível em: < http://www.scielo.br/scielo.php?pid=S003489102009000300001\&script=sci_abstract\&tlng=pt> Acesso em: 10 abr. 2015.

SCHEREINER R, D. et al. Pulmonary disease in the elderly patient. 1993:p.67-78.

SCHUMANN, L. A.; MOURA, L. B. A. Índices sintéticos de vulnerabilidade: uma revisão integrativa de literatura. Ciência \& Saúde Coletiva, v. 20, n. 7, p. 2105-2120, 2015.

SILVA, A. R.; SOUSA, A. I.; SANT'ANNA, C. C. Care practices employed in the treatment of children and adolescents with latent tuberculosis infection. Epidemiologia e Serviços de Saúde, v. 23, n. 3, p. 547-552, 2014. 
SINGH, Pramil N. et al. Cigarette smoking and tuberculosis in Cambodia: findings from a national sample. Tobacco induced diseases, v. 11, n. 1, p. 1, 2013.

SKABA, D. A. et al. Geoprocessamento dos dados da saúde: o tratamento dos endereços. Cad. Saúde Pública, v. 20, n. 6, p. 1753-1756, 2004.

SOUZA, M. S. P. L. et al. Fatores associados ao acesso geográfico aos serviços de saúde por pessoas com tuberculose em três capitais do Nordeste brasileiro. Cadernos de Saúde

Pública, v. 31, n. 1, p. 111-120, 2015. Disponível em:

$<$ http://www.scielosp.org/scielo.php?script=sci_arttext\&pid=S0102-

311X2015000100111\&lng=en\&nrm=iso>. Acesso em: 15 dez. 2015

SOUZA, S. S.; SILVA, D. M. G. V. Passando pela experiência do tratamento para

tuberculose. Texto contexto - Enfermagem, v. 19, n. 4, 2010. Disponível em

$<$ http://www.scielo.br/scielo.php?script=sci_arttext\&pid=S0104-

07072010000400005\&lng=pt\&nrm=iso>. Acesso em: 05 mar. 2015.

STARFIELD, B. Atenção primária: equilíbrio entre necessidades de saúde, serviços e tecnologia. UNESCO; Ministério da Saúde, 2002.

STORLA, D. G.; YIMER, S.; BJUNE, G. A. A systematic review of delay in the diagnosis and treatment of tuberculosis. BMC public health, v. 8, n. 1, p. 1, 2008.

STORY, A. et al. Tuberculosis in London-the importance of homelessness, problem drug use and prison. Thorax, v. 62, p. 667-671, 2007.

STYBLO, K.; MEJER, J.; SUTHERLAND, I. The transmission of tubercle bacilli: its trend in a human population. Bulletin of the World Health Organization, v. 41, n. 1, p. 137-178, 1969.

TEIXEIRA, E. C.; COSTA, J. S. O impacto das condições de vida e da educação sobre a incidência de tuberculose no Brasil. Revista de Economia, v. 37, n. 2, 2011.

TOLLEFSON, D. et al. Burden of tuberculosis in indigenous peoples globally: a systematic review [Review article]. The International Journal of Tuberculosis and Lung Disease, v. 17, n. 9, p. 1139-1150, 2013.

TOURAY, K. et al. Spatial analysis of tuberculosis in an urban west African setting: is there evidence of clustering?. Tropical Medicine \& International Health, v. 15, n. 6, p. 664-672, 2010.

TUBERCULOSIS, Surveillance Center TSC; RIT, JATA. TUBERCULOSIS ANNUAL REPORT 2014--(2) Tuberculosis in Pediatric and Elderly Patients. Kekkaku:[Tuberculosis], v. 91, n. 4, p. 481, 2016.

UNGLERT, C. V. S., 1995. Territorialização em sistemas de saúde. In: Distrito Sanitário (E. V. Mendes, org.), p. 221-235, São Paulo: Editora Hucitec/Rio de Janeiro: ABRASCO.

UYEMURA, K.; CASTLE, S. C.; MAKINODAN, T. The frail elderly: role of dendritic cells in the susceptibility of infection. Mechanisms of ageing and development, v. 123, n. 8, p. 955-962, 2002. 
VIACAVA, F. et al. Avaliação de Desempenho de Sistemas de Saúde: um modelo de análise/Evaluation of performance of health systems: a model for analysis. Ciênc. saúde coletiva, v. 17, n. 4, p. 921-934, 2004. Disponível em:

<http://www.scielo.br/pdf/csc/v17n4/v17n4a14.pdf>. Acesso em: 13 abr. 2015.

VIALI, L. Curso de Especialização em Estatística Aplicada. S.d. (Citado em 201503 de dezembro). Disponível em:

http://www.pucrs.br/famat/viali/especializa/realizadas/ceea/multivariada/laminas/CEEA_04.p df. Acesso em: 12 mar 2015.

WANG, Fahui. Measurement, optimization, and impact of health care accessibility: a methodological review. Annals of the Association of American Geographers, v. 102, n. 5, p. 1104-1112, 2012.

WATSON, D. F.; PHILIP, G. M. A refinement of inverse distance weighted interpolation. Geo-processing, v. 2, n. 4, p. 315-327, 1985.

WEN, C-P. et al. The reduction of tuberculosis risks by smoking cessation. BMC infectious diseases, v. 10, n. 1, p. 1, 2010.

WORLD HEALTH ORGANIZATION et al. Global tuberculosis report 2015. World Health Organization, 2015. Disponível em:

<http://http://apps.who.int/iris/bitstream/10665/191102/1/9789241565059_eng.pdf?ua=1>. Acesso em: 26 nov. 2015.

WORLD HEALTH ORGANIZATION. Definitions and reporting framework for tuberculosis - 2013 revision. Disponível em: <

http://apps.who.int/iris/bitstream/10665/79199/1/9789241505345_eng.pdf >. Acessado em: 10 abril 2016.

YAZDANI-CHARATI, J. et al. Spatial clustering of tuberculosis incidence in the North of Iran. Global journal of health science, v. 6, n. 6, p. 288, 2014.

YIMER, S.; BJUNE, G.; ALENE, G. Diagnostic and treatment delay among pulmonary tuberculosis patients in Ethiopia: a cross sectional study. BMC infectious diseases, v. 5, n. 1, p. 112, 2005.

ZUMLA, A. et al. Eliminating tuberculosis and tuberculosis-HIV co-disease in the $21 \mathrm{st}$ century: key perspectives, controversies, unresolved issues, and needs. Journal of Infectious Diseases, p. jir880, 2012. 
ANEXO

ANEXO 1 - Documento de Aprovação pelo Comitê de Ética

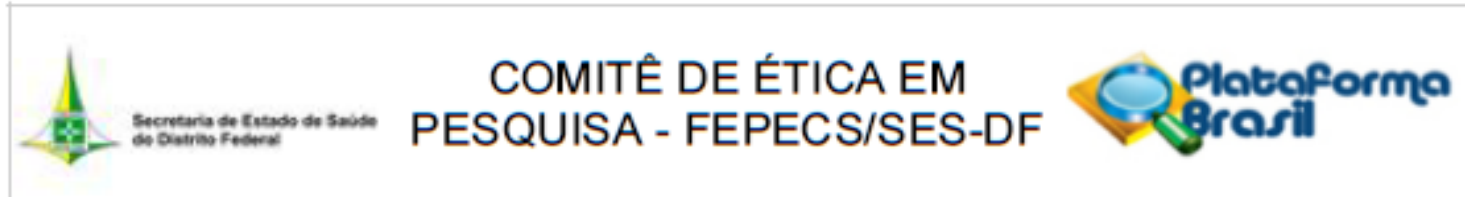

\section{PARECER CONSUBSTANCIADO DO CEP}

\section{DADOS DO PROJETO DE PESQUISA}

Título da Pesquisa: Análise espacial dos casos novos de tuberculose por Regiăo Admin istrativa do Distrito Federal no período de 2003 a 2012.

Pesquisador: Maria do Socorro Nantua Evangelista

Área Temática:

Versăo: 1

CAAE: 42947115.1 .0000 .5553

Instituição Proponente: Secretaria de Estado de Saúde do Distrito Federal / FEPECS/ SES/ DF

Patrocinador Principal: Financiamento Próprio

\section{DADOS DO PARECER}

Número do Parecer: 1.037 .141

Data da Relatoria: 23/03/2015

Apresentação do Projeto:

A pesquisa realizará uma análise espacial dos casos novos de Tuberculose por regiăo administrativa do Distrito Federal, a fim de verificar a distribuiçăo da doença utilizando técnicas de mapeamento geográfico (geoprocessamento). Assim será possivel identificar a localizaçăo dos casos novos de Tuberculose.

\section{Objetivo da Pesquisa:}

Objetivo Geral:

- Distribuir espacialmente os casos novos de tuberculose por Regiăo Administrativa do Distrito Federal no periodo de 2003 a 2012.

Objetivos especificos:

- Estimar o risco de adoecimento por tuberculose e a Regiåo Administrativa.

- Analisar os fatores socioeconômicos e demográficos dos casos novos de tuberaulose no período.

- Desenvolver estratégias que permitam um melhor acesso aos serviços de saúde pelo doente de TB, contribuindo para o aprimoramento da vigilância em saúde.

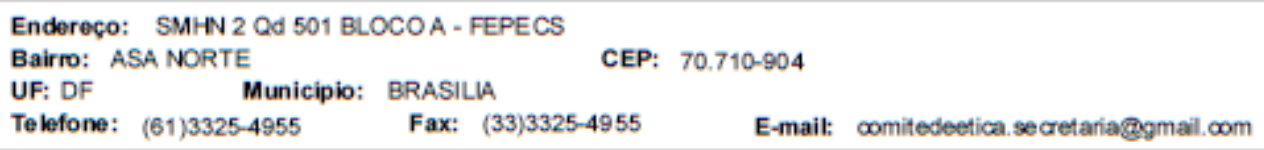




\section{COMITÊ DE ÉTICA EM PESQUISA - FEPECS/SES-DF \\ Q Platoforma} Secretarla de tatado do savis. cos ontras festere.

Continuacaso do Parecer: 1.037 .141

\section{Avaliaçăo dos Riscos e Benefícios:}

Riscos(segundo o pesquisador)

Em se tratando de uma pesquisa basicamente operacional, năo haverá uso "experimental" de sujeitos, nem contato para entrevistas ou coleta de material para exame laboratorial. O risco será mínimo para os participantes da pesquisa uma vez que a base de informaçőes será composta por dados secundários, disponiveis para o periodo de 2003 a 2012, provenientes do Programa de Tuberculose da Secretaria Estadual de Saúde (SINAN

-TB), do Instituto Brasileiro de Geografia e Estatística - IBGE e da Companhia de Planejamento do Distrito Federal - CODEPLAN. Para tanto será garantido o sigilo dos casos analisados, com a impossibilidade de uso nominal e ou a identificaçăo dos informantes sobre os dados em questăo, no âmbito do desenvolvimento da pesquisa.

Beneficios:

Este projeto será de interesse coletivo, uma vez que o geoprocessamento é uma poderosa ferramenta que poderá ser utilizada pelos profissionais da saúde para uma melhor compreensăo da distribuiçăo das doenças e dos agravos à saúde que mais acometem a populaçăo, especialmente a tuberculose, com vistas à identificaçăo das principais dificuldades no processo de controle dessa doença como problema de saúde pública no Brasil. Hoje, com os dados coletados pela ficha de notificaçăo / investigaçăo, se conhece a dimensăo dos casos novos de tuberculose por Regiăo Administrativa do DF, mas năo se sabe territorialmente como estes casos estăo distribuidos nesse espaço. Por sua vez, conhecer o risco de TB em cada grupo populacional, facilita otimizar os escassos recursos humanos e materiais, além de oportunizar que o serviço de TB priorize a assistência para às áreas de maior ris $\infty$ de desenvolver TB. Ou seja, com a visualizaçăo espacial dos grupos populacionais vulneráveis fará com que os profissionais de saúde possam agir diretamente nos locais de maior risco, de forma mais precoce, sem precisar esperar que o doente procure o serviço de saúde para o tratamento de TB. É de grande relevância para a vigilância sanitária e epidemiológica, uma vez que se concentram as açŏes de saúde nos locais de maior risco, diminuindo significativamente a propagaçăo da doença, melhorando a qualidade de vida da populaçăo e reduzindo gastos do setor saúde.Enfim, espera-se criar outras estratégias para o setor saúde, que busque a melhoria da vigilância epidemiológica dos casos de TB, como uma das ferramentas utilizadas para identificaçăo dos grupos de risco nas áreas mais acometidas

Endereço: SMHN 2 Qd 501 BLOCOA - FEPECS

Bairro: ASA NORTE

UF: DF Municipio: BRASILLA

Telefone: (61)3325-4955 Fax: (33)3325-4955 E-mail: comitedeetica.secretariaggmail.com 


\section{COMITÊ DE ÉTICA EM PESQUISA - FEPECS/SES-DF} Secretarta de tutads do swide is onsirios feseres:

Continuagaso do Parecer: 1.037 .141

pela doença.

\section{Comentários e Consideraçōes sobre a Pesquisa:}

Trata-se de um estudo quantitativo do tipo ecológico, a análise quantitativa será realizada por meio de uma análise espacial dos casos novos de tuberculose por RA's do Distrito Federal, a fim de verificar a distribuiçăo da doença, utilizando técnicas de mapeamento geográfico (geoprocessamento).

A pesquisa deverá ser composta por 31 Regiőes Admin istrativas (RA's) do Distrito Federal (DF) e analisarse-á os registros de casos novos de tuberculose no período de 2003 a 2012. Os dados deverăo ser coletados na Secretaria Estadual de Saúde do Distrito Federal, particularmente, no Programa de Tuberculose e a partir dos registros no ban $\infty$ de dados de TB - Sistema Nacional de Agravos de Notificaçăo (SINAN-DF). Farăo parte do estudo, todos os casos de TB registrados no DF no periodo, indiferente de raça, $\infty r$, etnia e escolaridade.

Consideraçōes sobre os Temmos de apresentaçăo obrigatória:

- Folha de Rosto e Termo de Concordância assinados pela DIVEP/SVS;

- Requerimento de Dispensa de Termo de Consentimento Livre e Esdarecido;

- Curriculum vitae das pesquisadoras apresentados;

- Cronograma de execuçăo e planilha de orçamento apresentadas:

- Referências bibliográficas apresentadas.

\section{Recomendaçőes:}

Após desenvolvimento do projeto, apresentar relatório final ao CEP/FEPECS/SES - DF.

Conclusōes ou Pendências e Lista de Inadequaçōes:

Projeto Aprovado.

Situaçăo do Parecer:

Aprovado

Necessita Apreciaçăo da CONEP:

Năo

Consideraçōes Finais a critério do CEP:

Endereço: SMHN 2 Qd 501 BLOCO A - FEPECS

Bairro: ASA NORTE

UF: DF Municipio: BRASILIA

Telefone: (61)3325-4955 Fax: (33)3325-4955 E-mail: comitedeetica.secretariagagmail.com 


\section{COMITÊ DE ÉTICA EM PESQUISA - FEPECS/SES-DF

